INSTITUTO DE PESQUISAS ENERGÉTICAS E NUCLEARES

Autarquia associada à Universidade de São Paulo

DESENVOLVIMENTO DE MÉTODO DE MEDIÇÃO DAS ESPESSURAS DE NÚCLEOS E REVESTIMENTOS DE PLACAS COMBUSTÍVEIS

Reinaldo Borges Júnior

Dissertação apresentada como parte dos requisitos para obtenção do grau de Mestre em Ciências na Área de Tecnologia Nuclear - Materiais

Orientador:

Prof. Dr. Michelangelo Durazzo

SÃO PAULO 
Aos meus grandes exemplos de vida, meus queridos pais,

Filomena Zorzi Borges e Reinaldo Borges. 


\section{AGRADECIMENTOS}

Primeiramente, agradeço ao meu grande professor e orientador, Dr. Michelangelo Durazzo, pela oportunidade concedida para a realização deste trabalho, pelas preciosas orientações dadas a cada dia e, mais ainda, pelo exemplo profissional. A somatória de todos esses fatores resultaraou nesta dissertação.

Ao M. Sc. Gilberto Hage Marcondes pela valiosa contribuição, tanto na área de análise de imagens, como em todo o procedimento experimental.

Ao técnico Jorge Clementino dos Santos, do Laboratório de Metalografia do IPEN, pela ajuda experimental e captação de dados.

Ao IPEN (Instituto de Pesquisas Energéticas e Nucleares) por toda a infraestrutura oferecida para que a pesquisa fosse possível.

Por fim, agradeço ao CNPq (Conselho Nacional de Desenvolvimento Científico e Tecnológico) e à CNEN (Comissão Nacional de Energia Nuclear) pelo apoio financeiro concedido durante toda esta etapa de Mestrado. 
"Se enxerguei longe, foi porque me apoiei nos ombros de gigantes" Isaac Newton 


\title{
DESENVOLVIMENTO DE MÉTODO DE MEDIÇÃO DAS ESPESSURAS DE NÚCLEOS E REVESTIMENTOS DE PLACAS COMBUSTÍVEIS
}

\author{
Reinaldo Borges Júnior
}

\begin{abstract}
RESUMO
Um dos componentes mais importantes de um Reator Nuclear é o Combustível Nuclear. Atualmente, o mais avançado combustível comercial, cuja aplicabilidade nos reatores brasileiros vem sendo desenvolvida pelo IPEN desde 1985, é o siliceto de urânio $\bigcup_{3} \mathrm{Si}_{2}$. Este é formado por placas combustíveis com núcleos de dispersão (onde o material físsil $\left(\mathrm{U}_{3} \mathrm{Si}_{2}\right)$ é disperso homogeneamente em uma matriz de alumínio) revestidos por alumínio. Tal combustível é produzido no Brasil com tecnologia totalmente nacional, resultado do esforço realizado pelo grupo de fabricação de combustíveis nucleares ( $\mathrm{CCN}$ - Centro do Combustível Nuclear) do IPEN. Diante da necessidade do aumento da potência do reator IEAR1 e da construção do Reator Multipropósito Brasileiro (RMB), para a produção de radioisótopos - principalmente para fins na área da medicina -, haverá significativo aumento na produção deste combustível nuclear no IPEN. Em face desta conjuntura, faz-se necessário o desenvolvimento de técnicas de qualificação mais modernas e automatizadas. Visando a este objetivo, neste trabalho foi desenvolvido um novo método computacional de medição de espessuras de núcleos e revestimentos de placas combustíveis, o qual é capaz de realizar tais medidas em tempo menor e com dados estatísticos mais significativos, quando comparado com o método atual de medição.
\end{abstract}




\title{
DEVELOPMENT METHOD FOR MEASURING THICKNESS OF NUCLEI AND COATING OF FUEL PLATES
}

\section{Reinaldo Borges Júnior}

\begin{abstract}
One of the most important components of a nuclear reactor is the Nuclear Fuel. Currently, the most advanced commercial fuel, whose applicability in Brazilian reactors has been developed by IPEN since 1985, is the silicide $U_{3} \mathrm{Si}_{2}$. This is formed by fuel plates with nuclei dispersion (where the fissile material $\left(\mathrm{U}_{3} \mathrm{Si}_{2}\right)$ is homogeneously dispersed in a matrix of aluminum) coated aluminum. This fuel is produced in Brazil with developed technology, the result of the efforts made by the group of manufacturing nuclear fuel (CCN - Center of Nuclear Fuel) of IPEN. Considering the necessity of increasing the power of the IEA- R1 and Brazilian Multipurpose Reactor Building (RMB), for the production of radioisotopes - mainly for the area of medicine - there will be significant increase in the production of nuclear fuel at IPEN. Given this situation, if necessary, make the development of more modern and automated classification techniques. Aiming at this goal, this work developed a new computational method for measuring thickness of core and cladding of fuel plates, which are able to perform such measurements in less time and with more meaningful statistical data when compared with the current method of measurement.
\end{abstract}




\section{SUMÁRIO}

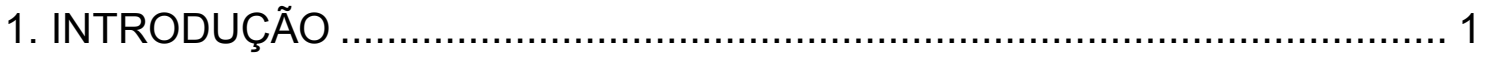

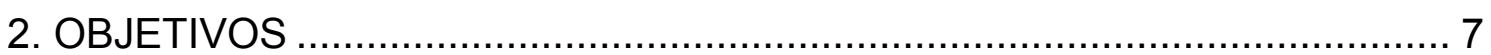

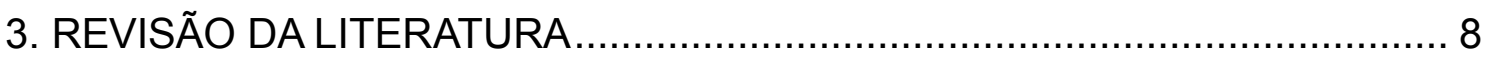

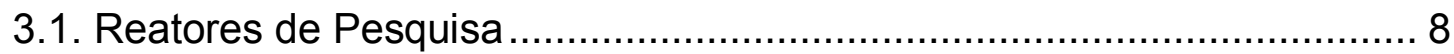

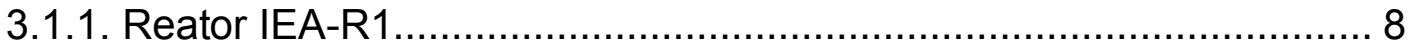

3.2. Combustíveis nucleares do tipo dispersão para reatores de pesquisa .. 10

3.3. Processos de fabricação do combustível tipo dispersão........................ 12

3.3.2. Processo de montagem do elemento combustível .......................... 23

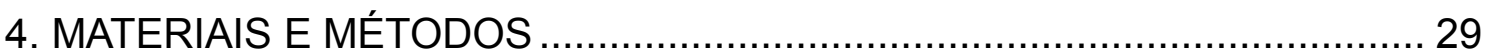

4.1.1. Operações de "pré-corte" e "corte" da placa combustível................ 31

4.1.2. Operação de "embutimento" ......................................................... 34

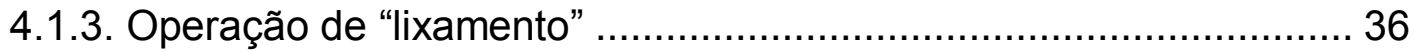

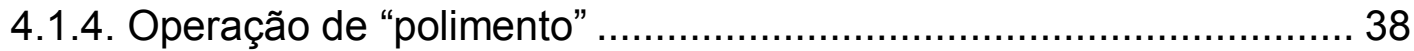

4.2. Atual processo de medição de espessuras de núcleos e revestimentos de

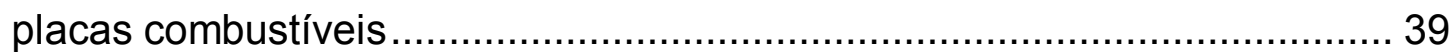

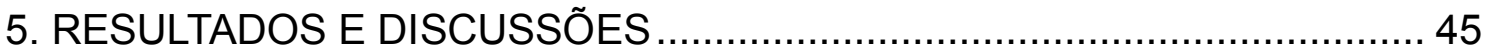

5.1. Quanto à obtenção das imagens para aplicação das Rotinas ............... 45

5.2. Quanto ao desenvolvimento do método de medição, ou criação das

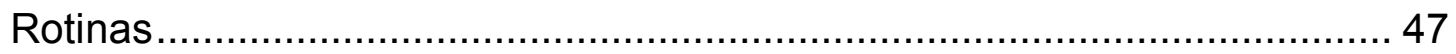

5.3. Quanto à aplicação do procedimento atual para comparação ............... 50

5.4. Quanto à aplicação das Rotinas ...................................................... 55

5.4.1. Aplicação das Rotinas para a placa Si809 …………………........ 55

5.4.2. Aplicação das Rotinas para a placa Si833 ...................................... 63

5.4.3. Aplicação das Rotinas para a placa Si852 ……............................. 69

5.5. Quanto à validação do novo método desenvolvido para medição de espessuras de núcleos e revestimentos de placas combustíveis ................. 75

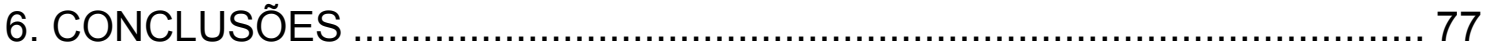

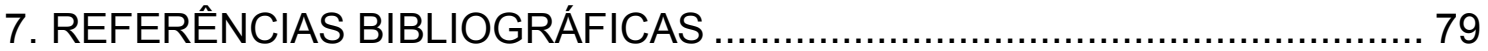




\section{LISTA DE FIGURAS}

Figura 1 - Seção longitudinal de um elemento combustível padrão utilizado no Reator Nuclear IEA-R1, mostrando detalhe de duas placas combustíveis sucessivas deste elemento [6].

\section{9}

Figura 2 - Diagrama de blocos simplificado do processo de fabricação de elementos combustíveis tipo placa.............................................................. 13

Figura 3 - Processo de fabricação do UF4 .................................................. 14

Figura 4 - Processo de fabricação de urânio metálico...................................... 16

Figura 5 - Processo de fabricação de siliceto de urânio.................................. 16

Figura 6 - Processo de preparação dos briquetes e desgaseificação............... 18

Figura 7 - Montagem das placas combustíveis [9] ..................................... 19

Figura 8 - Esquema ilustrativo da montagem do conjunto núcleo-moldura-

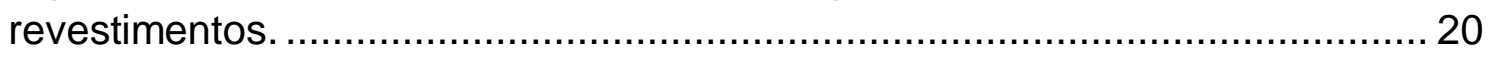

Figura 9 - Esquema ilustrativo da placa combustível laminada ....................... 21

Figura 10 - Processo de preparação dos conjuntos e laminação...................... 22

Figura 11 - Fixação da placa combustível nas placas suporte laterais [9] ...... 24

Figura 12 - Processo de montagem do elemento combustível......................... 24

Figura 13 - Esquema ilustrativo do elemento combustível fabricado no IPEN. 26 Figura 14 - Fluxograma simplificado das etapas de fabricação de elementos combustíveis tipo placa a base de dispersão [9] . ......................................... 27 Figura 15 - Processo de medição de espessuras de núcleos e revestimentos de

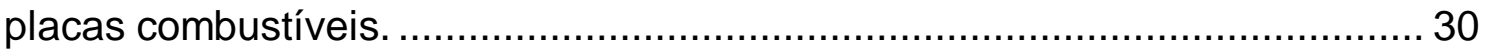

Figura 16 - Placa combustível cortada....................................................... 30

Figura 17 - Esquema de corte de regiões a serem analisadas para medidas de espessura de núcleo e revestimento de placas combustíveis.......................... 31

Figura 18 - Detalhes das sete regiões para visualização de pré-corte em guilhotina e corte em cortadeira com disco diamantado................................. 31

Figura 19 - Guilhotina utilizada no pré-corte de placas combustíveis. ............. 32

Figura 20 - Cortadeira Isomet com disco diamantado................................... 33

Figura 21 - Mapa para "embutimento" e reserva para contraprovas de amostras

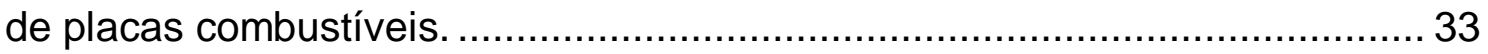

Figura 22 - Amostras, com grampos, no molde cilíndrico de plástico. ............. 34

Figura 23 - Preparação da resina para embutimento. ...................................... 35

Figura 24 - Embutimento com resina no molde cilíndrico................................ 35

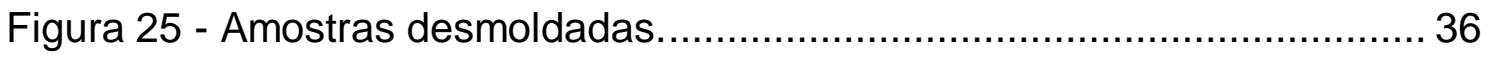

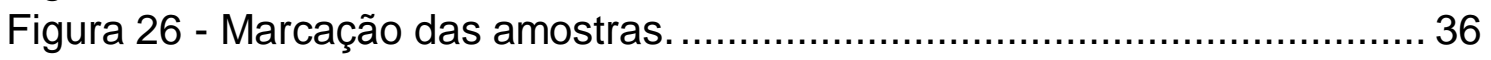

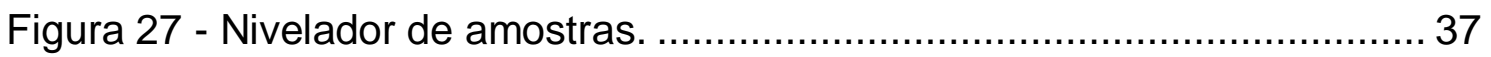

Figura 28 - Politriz semiautomática, para lixamento, com velocidade de rotação

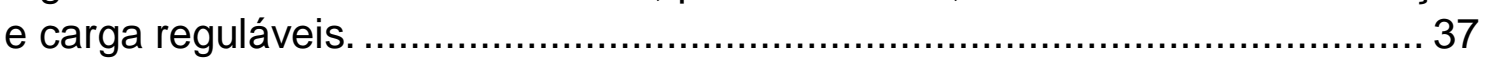

Figura 29 - Lixas empregadas na operação de lixamento................................ 38

Figura 30 - Politriz Minimet para polimento com sílica coloidal. ........................ 39 
Figura 31 - Analisador de Imagens Buehler, Omnimet Enterprise, com Microscópio Olympus PME3, Joystick para movimentação da Platina invertida e CPU dedicada.

Figura 32 - Típica imagem obtida no analisador de Imagens Buehler (Omnimet Enterprise) capturada no Microscópio Olympus PME3.

Figura 33 - Ilustração do procedimento atual, ou manual, para determinação das espessuras dos revestimentos e do núcleo da placa combustível. .................. 42

Figura 34 - Documento de qualificação do combustível.................................. 43

Figura 35 - Imagem obtida através do microscópio óptico. ............................. 46

Figura 36 -Imagem obtida por Microscopia Eletrônica de Varredura, para elétrons retro espalhados................................................................ 46

Figura 37 - Regiões da placa combustível. ................................................. 47

Figura 38 - Regiões A, B e C, capturadas por MEV (elétrons retroespalhados). 48

Figura 39 - "Rotina 1" criada para medição de espessuras de núcleos e revestimentos de placas combustíveis, para regiões terminais....................... 49 Figura 40 - "Rotina 2" criada para medição de espessuras de núcleos e revestimentos de placas combustíveis, para regiões centrais..........................49 Figura 41 - Passos da aplicação da Rotina 1, para regiões terminais da placa

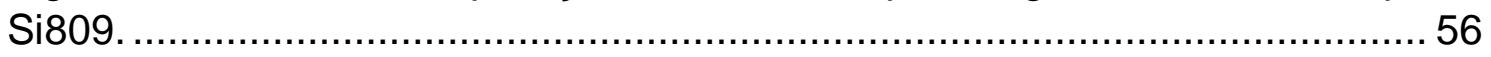

Figura 42 - Passos da aplicação da Rotina 2 para regiões não terminais da placa Si809.

Figura 43 - Imagem original, capturada por MEV (para elétrons

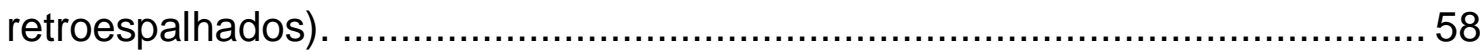

Figura 44 - Imagem após a aplicação da Rotina 1 ...................................... 58

Figura 45 - Histograma com a distribuição das espessuras no núcleo da placa

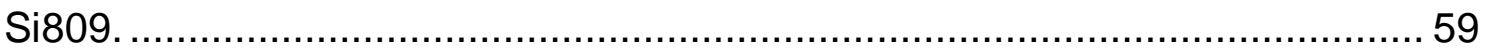

Figura 46 - Histograma com a distribuição das espessuras dos revestimentos da

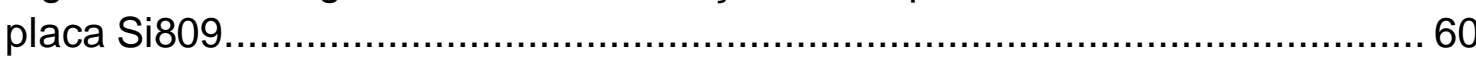

Figura 47 - Imagem original, capturada por MEV (elétrons retroespalhados). 61

Figura 48 - Imagem após a aplicação da Rotina 2 ...................................... 61

Figura 49 - Histograma com a distribuição das espessuras no núcleo da placa

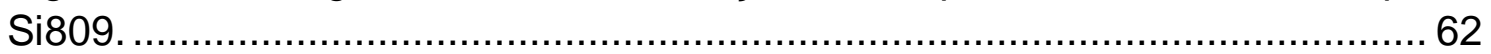

Figura 50 - Histograma referente aos revestimentos da placa Si809.............. 63

Figura 51 - Imagem original, capturada por MEV (elétrons retroespalhados). 64

Figura 52 - Imagem após a aplicação da Rotina 1...................................... 64

Figura 53 - Histograma com a distribuição das espessuras no núcleo da placa

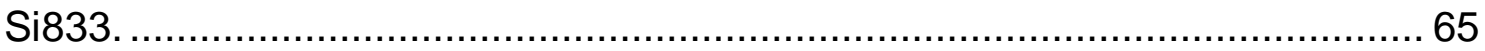

Figura 54 - Histograma com a distribuição das espessuras dos revestimentos da

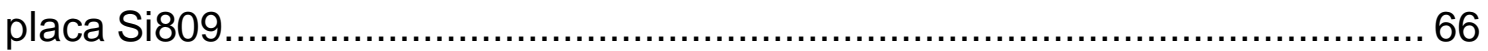

Figura 55 - Imagem original, capturada por MEV (elétrons retroespalhados). . 67

Figura 56 - Imagem após a aplicação da Rotina 2. ....................................... 67

Figura 57 - Histograma com a distribuição das espessuras no núcleo da placa

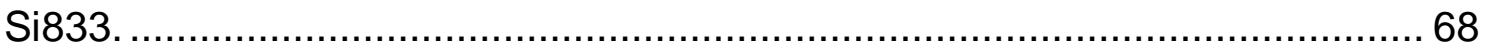

Figura 58 - Histograma referente aos revestimentos da placa Si833...............69

Figura 59 - Imagem original, capturada por MEV (elétrons retroespalhados). 70 
Figura 60 - Imagem após a aplicação da Rotina 1

Figura 61 - Histograma com a distribuição das espessuras no núcleo da placa Si852.

Figura 62 - Histograma com a distribuição das espessuras dos revestimentos da placa Si809.

Figura 63 - Imagem original, capturada por MEV (elétrons retroespalhados. .. 73 Figura 64 - Imagem após a aplicação da Rotina 2. 73

Figura 65 - Histograma com a distribuição das espessuras no núcleo da placa Si852.

Figura 66 - Histograma referente aos revestimentos da placa Si833. 75 


\section{LISTA DE FIGURAS}

Tabela 1 - Tabela de preenchimento manual, a partir o atual método de medição, para a placa Si809. 50

Tabela 2 - Tabela de preenchimento manual, a partir o atual método de medição, para a placa Si833. 52 Tabela 3 - Tabela de preenchimento manual, a partir o atual método de medição, para a placa Si852. 53 


\section{INTRODUÇÃO}

A utilização de radioisótopos na medicina é certamente uma das mais importantes aplicações sociais da energia nuclear. $0{ }^{99 \mathrm{~m} T c}$, gerado a partir do decaimento do ${ }^{99} \mathrm{Mo}$, é o radionuclídeo mais conveniente para a execução de procedimentos de tomografia computadorizada por emissão de fóton único, devido a dois fatores: sua emissão gama característica e de fácil detecção aliada à sua meia-vida de 6 horas, bastante apropriada para a realização de exames diagnósticos. O ${ }^{99} \mathrm{Mo}$, com meia-vida de 66 horas, é obtido por meio da fissão do ${ }^{235} \mathrm{U}$, sendo separado quimicamente dos produtos de fissão restantes. O ${ }^{99 \mathrm{~m} T c}$ é produto do decaimento do ${ }^{99} \mathrm{Mo}$, obtido por meio de geradores ${ }^{99} \mathrm{Mo} /{ }^{99 \mathrm{~m}} \mathrm{Tc}$, que fornecem o ${ }^{99 \mathrm{~m}} \mathrm{Tc}$ conforme o ${ }^{99} \mathrm{Mo}$ decai.

O uso do ${ }^{99 \mathrm{~m} T c}$ abrange $80 \%$ do total de procedimentos de diagnósticos por imagem nuclear, representando aproximadamente 30 milhões de procedimentos por ano em escala global. Essa porcentagem deverá continuar a crescer, tanto devido à conveniência de sua disponibilidade por meio de geradores ${ }^{99} \mathrm{Mo} /{ }^{99 m} \mathrm{Tc}$, como, também, pelo atraente custo efetivo do gerador. No Brasil, a demanda atual é de 320 geradores ${ }^{99} \mathrm{Mo} /{ }^{99 m} \mathrm{Tc}$ por semana, o correspondente a $4 \%$ da demanda mundial. Os geradores têm sido importados da NORDION, do Canadá, ao custo de 20 milhões de dólares por ano.

Há apenas cinco reatores de pesquisas envolvidos na produção de ${ }^{99} \mathrm{Mo}$ em escala industrial: o reator canadense NRU (National Research Universal Reactor - 135 MW, Chalk River, 1957); o reator holandês HFR (High Flux Reactor - 45 MW, Petten, 1961); o reator belga BR2 (Belgian Reactor 2 125 MW, Mol, 1961); o reator francês OSIRIS (70 MW, Saclay, 1966) e o reator sul-africano Safari-1 (20 MW, Pelindaba, 1965).

$\mathrm{O}{ }^{99}$ Mo deve ser extraído do alvo irradiado, operação que é realizada por quatro instalações de processamento principais. No Canadá, a AECL (Atomic Energy of Canada Limited) separa o ${ }^{99} \mathrm{Mo}$ dos alvos irradiados em Chalk River e a NORDION executa a purificação em Kanata. $\mathrm{Na}$ Holanda, todo o processamento é feito pela COVIDIEN, em Petten. Na Bélgica, o IRE (National Institute for Radioelements) é o responsável pela produção, em Fleurus. Na África do Sul, o processamento está nas mãos da NECSA (South African Nuclear 
Energy Corporation), em Pelindaba. O ${ }^{99}$ Mo é processado para a produção dos geradores ${ }^{99} \mathrm{Mo} /{ }^{99 m} \mathrm{Tc}$, o que é realizado por diversas companhias, das quais destacam-se a COVIDIEN holandesa, antiga Mallinckrdt, a Lantheus Medical Imaging americana, a GE Healthcare inglesa e a IBAMolecular francesa.

Os geradores são fornecidos a hospitais ou centros de radiofarmácia e podem ser usados por apenas uma semana, devido à perda de atividade de $1 \%$ por hora. Em circunstâncias normais, a cadeia de produção e fornecimento garante a disponibilidade mundial diária de ${ }^{99 \mathrm{~m} T c}$, em uma base de entrega semanal de geradores; cada parceiro deve atuar eficientemente de modo a assegurar o fornecimento ininterrupto e pontual do produto sob sua responsabilidade. Contudo, essa cadeia tem se mostrado vulnerável, resultando em graves crises no fornecimento - principalmente no seu ponto central, os reatores de pesquisas produtores de ${ }^{99} \mathrm{Mo}[1,2]$.

Todos os cinco principais atuais reatores de pesquisas produtores de ${ }^{99}$ Mo são antigos, com mais de 40 anos de uso; além disso, não são dedicados exclusivamente à produção de ${ }^{99} \mathrm{Mo}$. Alguns poucos reatores atendem a demandas regionais, como o reator australiano OPAL (Open Pool Australian Light-water Reactor - 20 MW, Lucas Heights, 2007), funcionando também como "backups" em caso de crise de fornecimento de ${ }^{99} \mathrm{Mo}$. Em decorrência da idade avançada, os principais reatores produtores de ${ }^{99}$ Mo estão sujeitos a cada vez mais frequentes e longas paradas para manutenção, impactando de forma negativa no fornecimento desse importante radioisótopo [3].

Em agosto de 2008, o reator HFR de Petten estava planejado para iniciar suas operações. Assim como havia sido programado, os reatores BR2, Osíris e NRU estavam parados para a realização de operações de manutenção. Ocorreu que, em decorrência da descoberta de corrosão e, possivelmente, de pequenos vazamentos no circuito primário do reator, o HFR não entrou em operação. Independentemente disso, na mesma época, um incidente no IRE, um dos responsáveis pelo processamento dos alvos irradiados, levou ao vazamento de ${ }^{131}$ I, o qual foi lançado através da chaminé de ventilação. Felizmente, esse incidente não causou qualquer efeito adverso na saúde dos trabalhadores e da população; de toda forma, a instalação teve sua operação interrompida. 
Além disso, uma das duas instalações de separação da Europa ficou indisponível e a outra, a COVIDIEN, teve que interromper suas atividades devido à falta de alvos irradiados. Repentinamente, só um dos principais reatores, o Safari-1 da África do Sul, manteve-se à disposição.

Depois de alguns dias, a produção de ${ }^{99}$ Mo foi retomada no Canadá, mas principalmente para o mercado da América do Norte. Graças aos esforços realizados pelos reatores OSÍRIS e BR2, no que diz respeito à irradiação de um máximo de alvos, e de um acordo para permitir que a COVIDIEN processasse os alvos destinados ao IRE, a COVIDIEN pode retomar o funcionamento no início de outubro. Após receber a permissão das autoridades, o IRE também voltou a operar em meados de novembro; já o reator HFR, apenas em fevereiro de 2009.

Devido a esta crise, centenas de milhares de pacientes não tiveram como realizar procedimentos de diagnóstico por imagem com base no ${ }^{99 \mathrm{~m}} \mathrm{Tc}$. Alguns dos exames puderam ser realizados por meio de técnicas alternativas, embora a um custo muito mais elevado. Outros exames foram realizados usando radioisótopos menos eficientes. Contudo, a maioria dos pacientes teve seus procedimentos adiados ou cancelados. Este foi o início da crise do ${ }^{99} \mathrm{Mo}$.

Em 2010, três dos cinco reatores produtores de ${ }^{99} \mathrm{Mo}$ (NRU, HFR e OSIRIS) ficaram fora de operação para manutenção. Depois do retorno em fevereiro de 2009, a operação do reator HFR foi novamente interrompida em fevereiro de 2010 para reparos no circuito primário de refrigeração, sendo reativada em setembro do mesmo ano. O reator NRU, depois da crise de 2008, paralisou sua operação em 2009, durante 11 meses, para reparos nas soldas do vaso do reator, retornando a operar em agosto de 2010. Atualmente, encontrase novamente fora de operação por um período previsto de 33 dias a partir de 15 de maio de 2011; a finalidade é a inspeção nas soldas realizadas na parada de 2009/2010.

Da análise desta situação, conclui-se que a comunidade médica mundial enfrenta atualmente uma "crise de radioisótopos médicos", gerada pela fragilidade da cadeia produtiva do ${ }^{99} \mathrm{Mo}$, fundamentada principalmente na idade avançada dos atuais reatores de pesquisa produtores deste radioisótopo. A coincidência de problemas técnicos que afetaram - ainda afetam e continuarão a afetar - simultaneamente vários reatores mostram a fragilidade da estrutura 
mundial para a produção de isótopos médicos. O montante de reatores de pesquisa está envelhecendo em todo o mundo, e a construção de novos reatores não compensa economicamente o encerramento da atividade dos antigos em operação, o que torna a crise difícil de ser resolvida e acena para seu agravamento, sobretudo quando considerado o aumento de demanda.

A estratégia brasileira para superar a crise do ${ }^{99}$ Mo é baseada em ações de curto, médio e longo prazo [4]. A ação em curto prazo foi concretizada pela compra de ${ }^{99}$ Mo da Argentina e, mais recentemente, da África do Sul (Safari1), além de distribuir geradores produzidos pela Bélgica e Israel. Os projetos de médio e longo prazo estão em pleno desenvolvimento e têm por objetivo a nacionalização da produção do radioisótopo em questão. A médio prazo, será produzido ${ }^{99}$ Mo por meio de ativação com nêutrons, a qual depende do aumento da potência do reator IEA-R1 do IPEN de 4 para 5 MW. Já o projeto a longo prazo depende da construção de um novo reator de pesquisas, de potência substancialmente superior à potência do reator IEA-R1, por ora o único reator produtor de radioisótopos do país. O novo reator é chamado Reator Multipropósito Brasileiro (RMB) e está previsto para ter potência de $30 \mathrm{MW}$, a ser construído em Iperó, cidade próxima à cidade de São Paulo. O RMB terá capacidade para produzir ${ }^{99}$ Mo por fissão, por meio da irradiação de alvos contendo urânio LEU (Low Enriched Uranium), ou seja, urânio de baixo enriquecimento em ${ }^{235} \mathrm{U}$, além de permitir a produção de ${ }^{99}$ Mo por captura de nêutrons, que é justamente o projeto de médio prazo.

A Comissão Nacional de Energia Nuclear (CNEN) realizou em 3 de setembro de 2008 a reunião de abertura para o Projeto Reator Multipropósito Brasileiro (RMB). O RMB será um reator tipo piscina aberta, com circuito de refrigeração forçada no primário. O núcleo será refrigerado e moderado com água leve, sendo utilizados berílio e água pesada como refletores. O núcleo também será compacto, visando a atingir um fluxo de nêutrons superior a 2×1014 ncm2. O RMB está orçamentado em $R \$ 850$ milhões, dos quais $R \$ 50$ milhões foram liberados para o projeto básico em maio de 2010. O projeto para a construção do Reator Multipropósito Brasileiro (RMB) foi aprovado pela Comissão de Monitoramento e Avaliação (CMA), do Plano Plurianual do Governo, conforme publicação feita no Diário Oficial da União, em 1 de março 
de 2011. A CMA aprovou o parecer da Câmara Técnica de Projetos de Grande Vulto (CTPGV), a qual foi favorável ao projeto pela importância técnica e socioeconômica. Uma recente análise de sustentabilidade do Projeto RMB demonstrou que a infraestrutura do país atende a $74 \%$ dos requisitos analisados, favorecendo, assim, sua a implantação [5].

O cronograma para execução do projeto RMB prevê o início da operação do reator em 2015. Ficou decidido que o IPEN será o responsável pela fabricação dos elementos combustíveis do reator, o qual iniciará a produção do primeiro núcleo do reator em 2014, num total de 24 elementos combustíveis. Devido à sua maior potência, estima-se que o Reator RMB consumirá 50 elementos combustíveis anualmente, número significativamente superior ao consumo atual do Reator IEA-R1. Assumindo-se que os dois reatores operarão simultaneamente, o consumo total de elementos combustíveis é estimado em 60 ao ano.

O IPEN, em sua história, já vem desenvolvendo e fabricando rotineiramente o tipo de combustível que será utilizado no Reator RMB; apesar disso, ao se tornar o responsável pelo fornecimento de todo o combustível necessário para a operação desses reatores de pesquisa, terá como desafio aumentar a produtividade das instalações para atender à futura demanda. A capacidade atual de produção de elementos combustíveis do IPEN, que é de apenas 10 elementos combustíveis anuais, será aumentada para 60. Segundo o cronograma do Projeto RMB, isto deverá ser concretizado até o ano de 2016.

O combustível comercial mais avançado atualmente, e cuja aplicabilidade nos reatores brasileiros é desenvolvida no IPEN desde 1985, é o siliceto de urânio $U_{3} \mathrm{Si}_{2}$. Este é formado por placas combustíveis (revestidas de alumínio) com núcleos de dispersão, onde um composto de urânio é disperso homogeneamente em alumínio (por esse motivo, é dito ser este combustível à base de dispersão). Hoje, tal combustível é produzido no Brasil com tecnologia totalmente nacional, fato que é resultado do esforço realizado pelo grupo de fabricação de combustíveis do IPEN, CCN, em resposta à dificuldade de adquirir esse combustível no mercado internacional na primeira metade da década de 80 , assim como à decisão de aumentar a potência e o regime de operação do 
reator IEA-R1 para fazer frente à necessidade de aumentar a produção de radioisótopos.

A infraestrutura disponível atualmente para a produção desse tipo de combustível é suficiente para garantir apenas o suprimento do combustível necessário para a operação do reator IEA-R1 do IPEN, único desse tipo existente no Brasil e apto a produzir radioisótopos. Contudo, a maior severidade das condições operacionais do reator RMB e o maior consumo exigem que seja atingido um novo patamar tecnológico em termos de qualidade do produto e produtividade da instalação de fabricação.

Nesse sentido, se faz presente a necessidade de um novo avanço tecnológico na área de fabricação de combustíveis de dispersão tipo placa para uso em reatores de pesquisas produtores de radioisótopos. Em consequência, a implantação de técnicas de qualificação mais modernas e automatizadas se tornou inadiável. Este é o contexto no qual o presente trabalho se insere e seu objetivo é consonante com o quadro e com a tendência brasileira na área de combustíveis de dispersão para reatores produtores de radioisótopos modernos. 


\section{OBJETIVOS}

A geração de parâmetros quantitativos, relativos às espessuras do núcleo e dos revestimentos de placas combustíveis, é importante na qualificação do combustível nuclear tipo dispersão e deve atender aos requisitos no projeto da placa combustível.

Tais parâmetros, de acordo com a metodologia proposta neste trabalho, serão obtidos de forma automatizada, através do desenvolvimento de um procedimento computacional mais rápido e eficiente do que o adotado atualmente - reduzindo o tempo de análise de 288 horas (12 dias) para 72 horas (3 dias). Esse novo procedimento de medição de núcleos e revestimentos possibilitará, além de maior rapidez (fato importante para a produção e fornecimento de elementos combustíveis para o Reator Multipropósito Brasileiro), a obtenção de dados estatisticamente mais significativos, quando comparados aos dados obtidos pelo procedimento de medição atualmente empregado. 


\section{REVISÃO DA LITERATURA}

\subsection{Reatores de Pesquisa}

Classifica-se os reatores nucleares segundo alguns critérios, dentre os quais: a energia dos nêutrons em que ocorrem as fissões nucleares; o elemento físsil presente no combustível nuclear; a combinação do conjunto composto pelo combustível nuclear e pelo moderador; o tipo de moderador; o tipo de fluido refrigerante e a finalidade a que se destinam. Mas, dentre todos os critérios, um dos principais é o que se refere ao objetivo dos reatores nucleares.

De acordo com tais parâmetros, os reatores nucleares são agrupados em dois tipos principais: Reatores Nucleares de Pesquisa e Reatores Nucleares de Potência. Os primeiros servem como fontes de nêutrons para múltiplos propósitos - desde a área da Física Nuclear até irradiações para produção de radioisótopos, para uso na Medicina e na Agricultura. Por seu turno, os Reatores de Potência são, a princípio, projetados para geração de energia elétrica.

A seguir, são apresentadas algumas características das instalações pertencentes ao IPEN/CNEN-SP [6].

\subsubsection{Reator IEA-R1}

O Reator IEA-R1 foi projetado e construído pela empresa norteamericana Babcock \& Wilcox Co., de acordo com as diretrizes fornecidas pela Comissão de Energia Atômica dos EUA. Tal Reator tipo piscina está localizado nas dependências do IPEN/CNEN-SP, na Cidade Universitária, em São Paulo.

No dia 16 de setembro de 1957, o IEA-R1 atingiu sua primeira criticalidade. Desde então, utiliza-se este reator para produção de radioisótopos em análise de materiais por ativação, em experimentos científicos e em treinamento de pessoal - operando em potência de $5 \mathrm{MW}$.

Seu núcleo possui um total de 24 elementos combustíveis, estrategicamente posicionados em um arranjo $5 \times 5$. A posição central do arranjo é ocupada por um elemento de irradiação composto por berílio e não por elemento combustível. Dos 24 elementos combustíveis, 4 são para inserção de barras de controle e os outros 20 são denominados elementos combustíveis padrão MTR (sigla para designar "Materials Testing Reactor"). Cada um destes 
é composto por 18 placas combustíveis planas e paralelas, montadas em placas suportes laterais, cujos detalhes estão apresentados na Figura 1 abaixo.

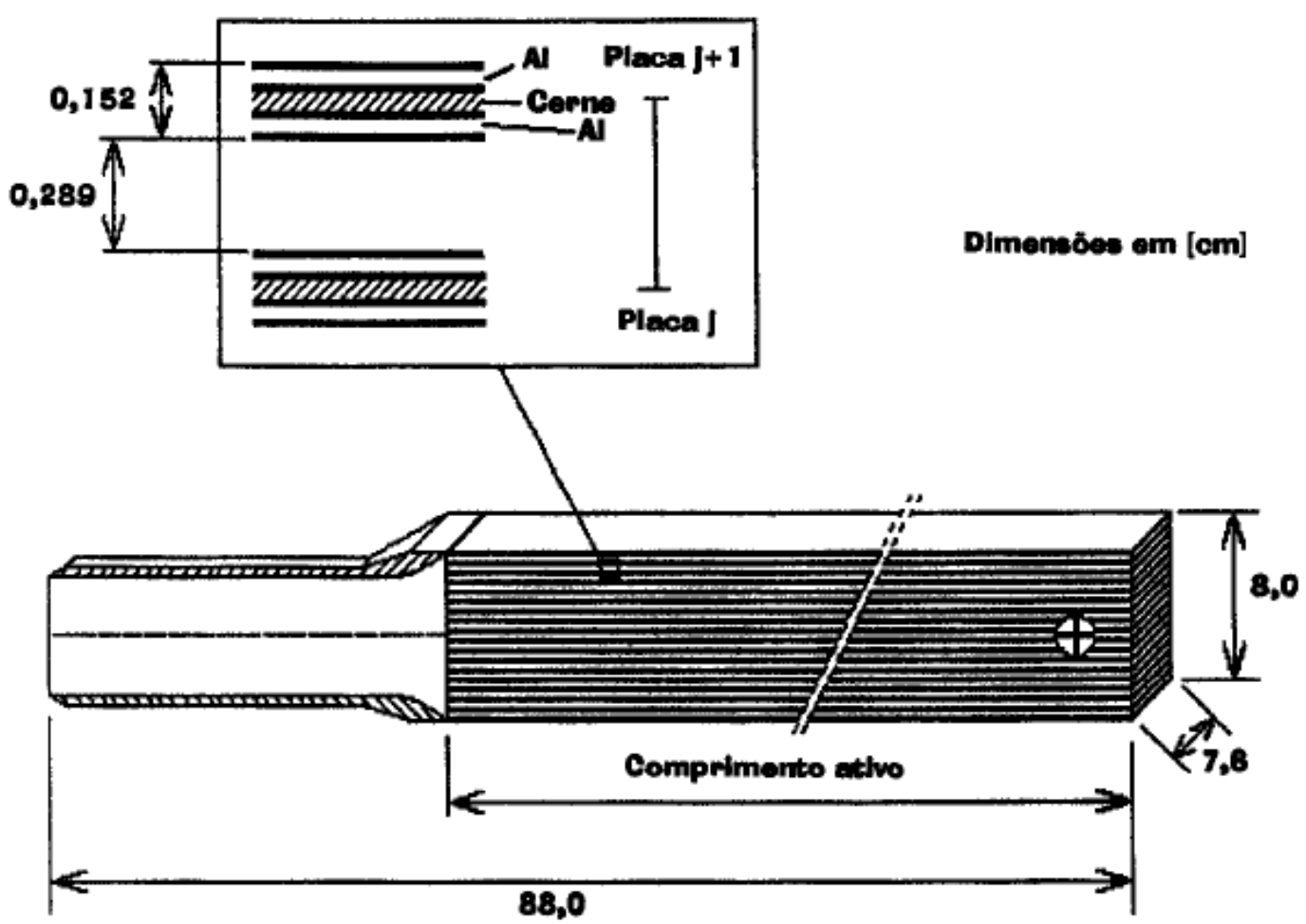

Figura 1 - Seção longitudinal de um elemento combustível padrão utilizado no Reator Nuclear IEA-R1, mostrando detalhe de duas placas combustíveis sucessivas deste elemento [6].

As placas combustíveis possuem um cerne (ou núcleo), onde fica alojado o combustível nuclear, o qual é revestido por duas camadas de alumínio $[7,8]$.

Desde setembro de 1997, o referido Reator opera com combustíveis fabricados no próprio IPEN/CNEN-SP. Tais combustíveis são do tipo $\mathrm{U}_{3} \mathrm{O}_{8} \mathrm{e}$ $\mathrm{U}_{3} \mathrm{Si}_{2}$ dispersos em uma matriz de alumínio. A água contida em sua piscina é desmineralizada e carrega a função de moderador e refletor para nêutrons, além de atuar como refrigerador para o núcleo e como blindagem biológica para os operadores.

O controle do Reator é feito através de quatro barras absorvedoras de nêutrons, sendo que uma dela é utilizada como barra de controle e as outras três funcionam como barras de segurança. Cada uma das barras é formada por uma liga de prata-índio-cádmio, revestida por uma fina camada de níquel. 


\subsection{Combustíveis Nucleares do tipo dispersão para Reatores de Pesquisa}

O combustível nuclear é um dos elementos mais importantes no funcionamento de um Reator Nuclear. Sua função é fornecer energia, por meio da fissão nuclear, para alimentar o funcionamento do reator [9]. Em todo o mundo, numerosos reatores de pesquisas fazem uso de elementos combustíveis tipo placa; tal se dá a partir da montagem de placas combustíveis, fabricadas seguindo a técnica: núcleo (o qual incorpora o material físsil), moldura e revestimentos, com posterior deformação por laminação ("picture frame technique") $[7,8]$.

Inicialmente, este tipo de combustível utilizava como material do núcleo ligas de urânio-alumínio (U-Al), contendo $18 \%$ em peso de urânio altamente enriquecido $-93 \%$ em peso de ${ }^{235} \cup[7,10]$. Na década de 50 [11], diante da preocupação com a não proliferação de armamentos nucleares, começou-se a utilizar combustíveis contendo urânio com baixo enriquecimento $-20 \%$ em peso de ${ }^{235} \mathrm{U}$ - em reatores de pesquisas de baixa potência. Todavia, para que a reatividade e a vida útil dos caroços dos reatores não fosse diminuída, tornou-se necessário o aumento da quantidade de urânio em cada placa combustível. Placas combustíveis comportando núcleos à base da liga U-Al com $18 \%$ em peso de urânio altamente enriquecido eram facilmente fabricadas; entretanto, surgiram dificuldades na fabricação de placas combustíveis com núcleos de liga U-Al com $45 \%$ em peso de urânio com baixo enriquecimento em decorrência da fragilidade e propensão à segregação desta liga $[11,12,13]$.

Uma alternativa encontrada para este problema foi a utilização de núcleos fabricados por metalurgia do pó, os quais utilizavam dispersões de compostos de urânio em alumínio e podiam incorporar quantidades de urânio com baixo enriquecimento sensivelmente maiores. Em 1956, iniciou-se a operação do Reator Argonauta (10 MW), desenvolvido pelo Argonne National Laboratory (ANL), utilizando placas combustíveis com núcleos à base da dispersão $\mathrm{U}_{3} \mathrm{O}_{8}-\mathrm{Al}$, contendo $39 \%$ em peso de $\mathrm{U}_{3} \mathrm{O}_{8}$ com baixo enriquecimento [14]. Mais esforços foram realizados com o objetivo de aumentar a concentração de urânio neste tipo de dispersão, obtendo-se, até o final da década de 70, um máximo de $65 \%$ em peso de $\mathrm{U}_{3} \mathrm{O}_{8}$, no combustível, para o Reator de Pesquisa Puerto Rico (Puerto Rico Research Reator) do Puerto Rico Nuclear Center [15]. 
Entretanto, com desenvolvimento de Reatores Nucleares de Pesquisas com maiores potências (para obtenção de altos fluxos de nêutrons), tornou-se necessário dar continuidade à produção de combustíveis nucleares que utilizavam urânio altamente enriquecido (93\% em peso de ${ }^{235} \mathrm{U}$ ), visando à obtenção de maior reatividade específica, uma vez que estes combustíveis podiam permanecer mais tempo no núcleo do reator - adquirindo maior vida útil.

O HFIR [16] (High Flux Isotope Reactor), com potência de 100 MW, utilizou dispersões de $\mathrm{U}_{3} \mathrm{O}_{8}$-Al com $40 \%$ em peso de $\mathrm{U}_{3} \mathrm{O}_{8}$. Já o ATR [17] (Advanced Test Reactor), com $250 \mathrm{MW}$ de potência, utilizava o mesmo tipo de dispersão, com $34 \%$ em peso de $\mathrm{U}_{3} \mathrm{O}_{8}$. Além das dispersões de $\mathrm{U}_{3} \mathrm{O}_{8}-\mathrm{Al}$, utilizavam-se as dispersões de $\mathrm{UAl}_{x}-\mathrm{Al}$ e as ligas de U-Al, com urânio altamente enriquecido. Ao fim da década de 70 , a máxima densidade de urânio obtida qualificada foi de $1,7 \mathrm{gU} / \mathrm{cm}^{3}$. Nesta época, obtinha-se facilmente urânio altamente enriquecido, de modo que os reatores que utilizavam urânio com baixo enriquecimento foram gradualmente convertidos para operarem com o outro combustível. Desta maneira, chegou-se a um número de aproximadamente 156 reatores de pesquisas, em 34 países, utilizando urânio altamente enriquecido, o que resultou em uma circulação de aproximadamente 5000 quilogramas por ano deste material [18].

Em 1977, ressurgiu a preocupação com o risco de proliferação nuclear, a qual estava associada ao extravio deste combustível durante sua fabricação, transporte e armazenamento. Tal fato levou o governo americano a restringir a comercialização de urânio com alto grau de enriquecimento (acima de $90 \%$ em peso de ${ }^{235} \mathrm{U}$ ), produzindo grande impacto na disponibilidade e utilização deste combustível para reatores de pesquisas.

A partir de 1978, foram estabelecidos programas de redução de enriquecimento que objetivavam o desenvolvimento da base tecnológica capaz de garantir a substituição, em Reatores Nucleares de pesquisas, do urânio altamente enriquecido ( $=$ ou $>20 \%{ }^{235} \mathrm{U}$ ) por urânio com baixo enriquecimento (abaixo de $20 \%$ em peso de ${ }^{235} \mathrm{U}$ ). O principal deles, ainda ativo nos dias de hoje, é o Programa RERTR (Reduced Enrichment for Research and Test Reactors), cuja meta é o desenvolvimento da tecnologia necessária para essa conversão. 
Durante a existência desse programa, cerca de 40 reatores de pesquisas foram convertidos, dentre eles o reator IEA-R1, do IPEN/CNEN-SP.

Desta vez, a redução de enriquecimento exige esforço superior ao verificado anteriormente, pois em reatores de potências mais elevadas, e projetados para operar em condições extremas, esta substituição implica no desenvolvimento e qualificação de combustíveis com a máxima concentração de urânio possível, cujos limites são impostos pela fabricação e desempenho sob irradiação severa e prolongada.

Buscam-se alternativas para que reatores de pesquisa obtenham melhor desempenho em seu funcionamento. Para tanto, é necessária a utilização de materiais combustíveis LEU de alto desempenho e estáveis sob irradiação, evitando que se coloque em risco a segurança da operação do reator nuclear. Para que seja respeitado o limite de enriquecimento do urânio, exigido pelo Programa RERTR, é necessário aumentar a concentração de urânio no núcleo das placas combustíveis tipo dispersão.

O caminho do desenvolvimento tecnológico se dá no sentido de conseguir materiais capazes de permitir maiores densidades de urânio no núcleo de combustível nuclear [19]. Por conta disso, passou-se a fazer o uso de placas de elementos combustíveis com núcleos de dispersões, onde as partículas da fase dispersa se encontram uniformemente distribuídas em uma matriz contínua de material não físsil - na maioria dos casos este material é o alumínio.

Uma das principais vantagens dos elementos combustíveis à base de dispersão é que estes possibilitam a fabricação de núcleos com uma grande variedade de concentrações das fases dispersas. Outra vantagem é que os mesmos são mais resistentes a danos causados pela irradiação em sua operação; esta grande estabilidade se deve ao fato de os produtos de fissão permanecerem acumulados dentro, ou nas vizinhanças, de partículas dispersas do combustível, prevenindo danos no núcleo do combustível [20, 21].

\subsection{Processos de fabricação do Combustível tipo dispersão}

De modo geral, o processo de fabricação de elementos combustíveis tipo placa apresenta as principais etapas ilustradas no diagrama de blocos da Figura 2 abaixo. 


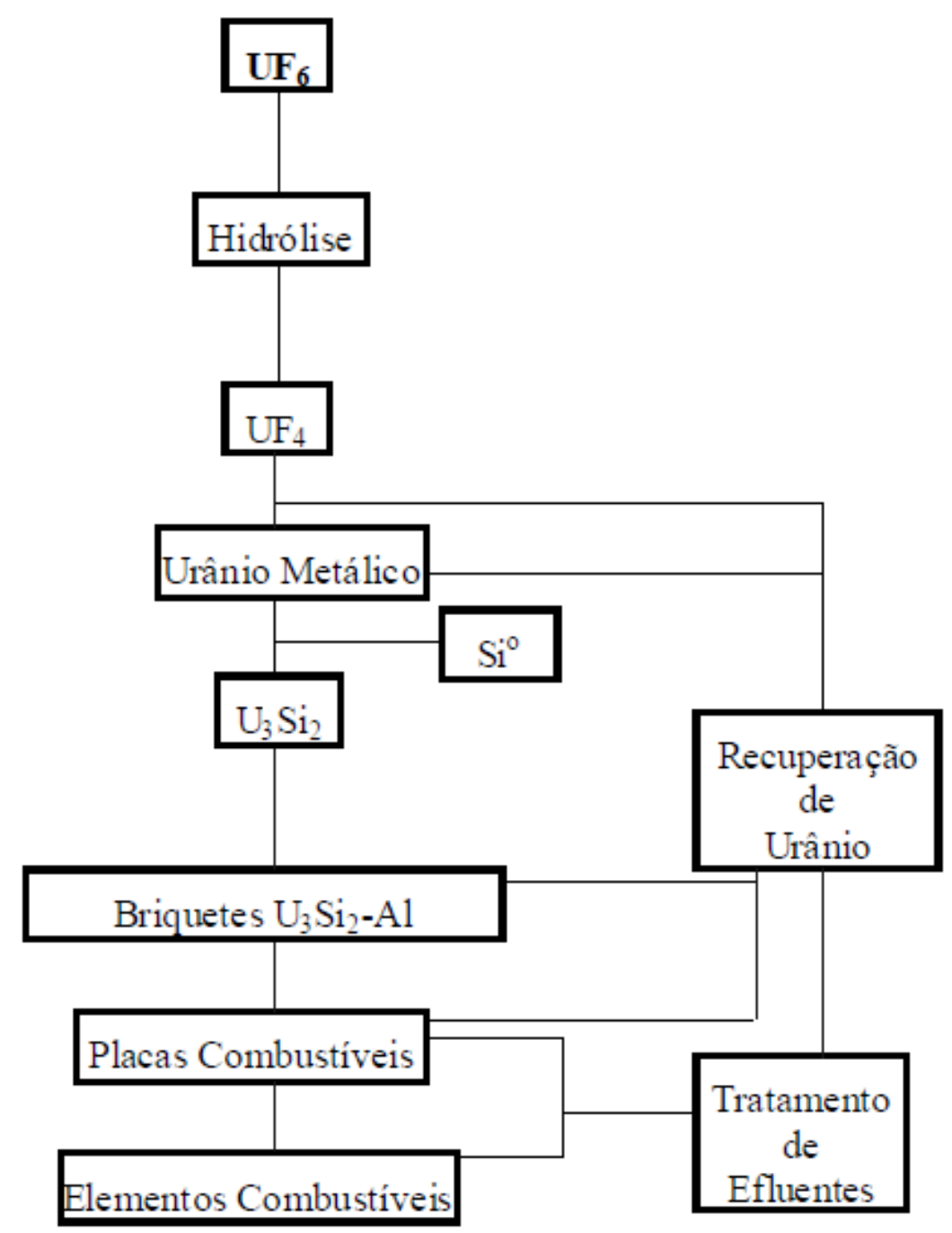

Figura 2 - Diagrama de blocos simplificado do processo de fabricação de elementos combustíveis tipo placa.

A seguir, serão descritos os processos de fabricação das placas combustíveis e de montagem do elemento combustível tipo dispersão, realizada no IPEN.

\subsubsection{Processo de fabricação de placas combustíveis}

O processo de fabricação das placas combustíveis inicia-se com a reconversão do $\mathrm{UF}_{6}$ (hexafluoreto de urânio) enriquecido a $\mathrm{UF}_{4}$ (tetrafluoreto de urânio). O esquema da figura abaixo (Figura 3) ilustra o processo de fabricação do pó de $U_{4}$ a partir do UF 6 . O UF 6 é transformado em uma solução de fluoreto de uranilo $\left(\mathrm{UO}_{2} \mathrm{~F}_{2}\right)$ obtida por meio de hidrólise. 


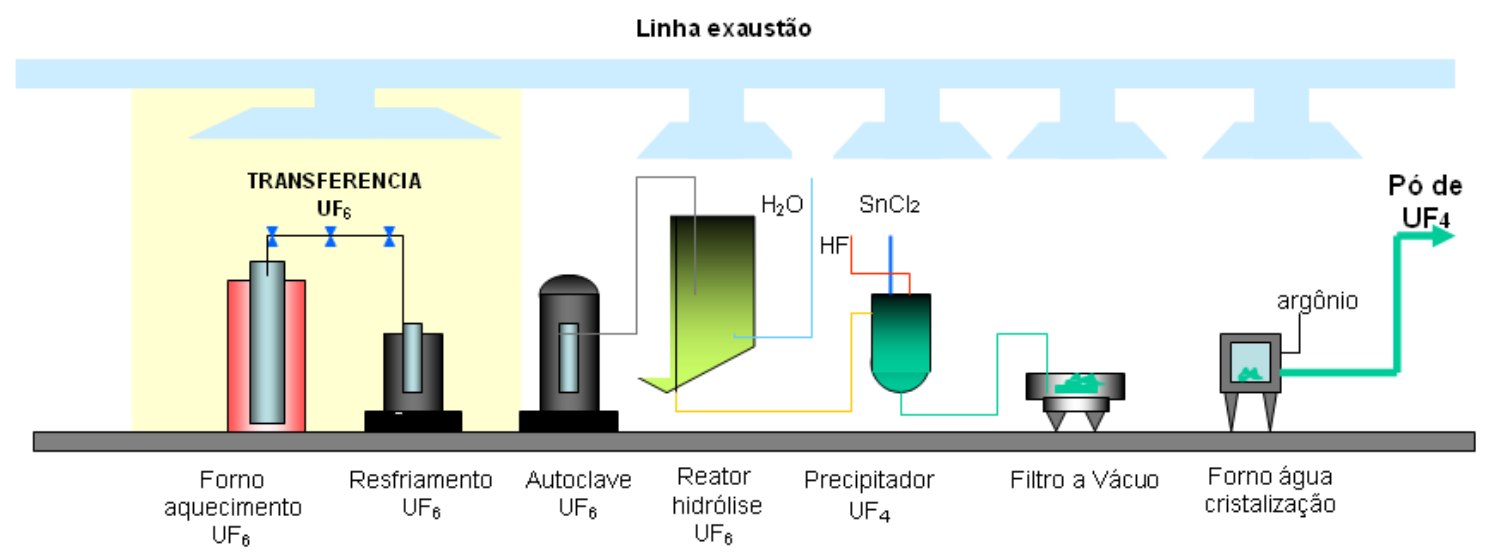

Figura 3 - Processo de fabricação do UF4.

O UF 6 liberado do cilindro é introduzido no reator de hidrólise por meio de um bico tipo venturi acionado pela recirculação da solução aquosa de fluoreto de uranilo formada. Inicialmente, o reator de hidrólise é preenchido com 25 litros de água deionizada, a qual reage com o $U_{6}$ formando a solução de $U_{2} \mathrm{~F}_{2}$. $\mathrm{O}$ $U_{6}$ é injetado na base do reator, onde é borbulhado na solução, reagindo imediatamente para a formação do fluoreto de uranilo. Ao final da operação, obtém-se 50 litros de uma solução de $\mathrm{UO}_{2} \mathrm{~F}_{2}$ com concentração de aproximadamente 40 gramas de urânio/litro.

A solução de fluoreto de uranilo oriunda do reator de hidrólise é transferida para o reator de precipitação de $U_{4}$ e, neste reator, o urânio contido em solução é reduzido a $\mathrm{U}^{4+}$ utilizando-se como agente redutor o cloreto de estanho II, sendo o urânio precipitado na forma de UF 4 mediante a adição de HF.

A suspensão obtida é transferida do reator de precipitação para o sistema de filtração. O UF 4 precipitado contido no filtro é recolhido manualmente, acondicionado em bandejas e introduzido em estufa para retirada da umidade. Posteriormente, o UF 4 seco é enviado ao sistema de secagem para retirada da água de cristalização. O material é acondicionado no interior de uma retorta, a qual é posteriormente inertizada com um fluxo de argônio e inserida em uma mufla elétrica para aquecimento. $\mathrm{O}$ ciclo de secagem é de 1 hora à temperatura de $400^{\circ} \mathrm{C}$. Após a operação de secagem, o UF 4 é retirado manualmente da retorta e acondicionado em recipiente hermético. $\mathrm{O} \mathrm{UF}_{4}$ obtido é a matéria-prima para a fabricação do urânio metálico e, posteriormente, do $U_{3} \mathrm{Si}_{2}$. O pó de $U_{4}$ é utilizado para a obtenção de urânio metálico por meio de uma reação 
magnesiotérmica em um vaso cilíndrico construído em aço resistente à temperatura, denominado Bomba de Redução. Este urânio metálico é, posteriormente, processado para obtenção do intermetálico $\mathrm{U}_{3} \mathrm{Si}_{2}$ por fusão e por indução, dando origem a um lingote. O pó de UF 4 é pesado e inserido em um misturador (tipo V), instalado no interior de uma caixa de luvas e homogeneizado, garantindo este mesmo traço às suas características físico-químicas.Após essa homogeneização, o magnésio metálico previamente pesado é adicionado ao pó de $\mathrm{UF}_{4}$ contido no misturador, formando-se a carga de redução. A bomba de redução consiste em um vaso cilíndrico que permite o acoplamento, por meio de engate rápido (flange), de uma tampa que pode ser refrigerada com ar comprimido. O cadinho, confeccionado em grafite pirolítico, é inserido no interior do corpo da bomba já preenchido com a carga de redução. A mistura homogeneizada obtida de $\mathrm{UF}_{4} \mathrm{e} \mathrm{Mg}^{0}$ é colocada no interior do cadinho de grafite que, por sua vez, é carregado na bomba de redução. A bomba carregada é inserida no interior do forno de redução, o qual é tipo poço. Inicia-se o processo de aquecimento do forno até um patamar de $600^{\circ} \mathrm{C}$. Sob esta temperatura, a bomba é evacuada várias vezes e purgada com argônio, mantendo-se uma pressão interna de 0,4 bar. A carga sofre, então, ignição espontânea e ocorre a reação: $U F_{4}+2 M g^{0} \Rightarrow U^{0}+2 M g F_{2}$.

Como resultado da vigorosa reação exotérmica, o urânio metálico formado na reação do $\mathrm{UF}_{4} \operatorname{com}$ o $\mathrm{Mg}^{0}$ é fundido (ponto de fusão de $1130{ }^{\circ} \mathrm{C}$ ) e escorre, favorecido pela sua alta densidade, para o fundo do cadinho de grafite. A escória de $\mathrm{MgF}_{2}$ se separa, deslocando-se para a superfície. O processo todo ocorre em poucos segundos. Finalmente, a bomba de redução é tirada do forno por meio da talha e é resfriada, após o que a tampa da bomba é removida e o cadinho de grafite contendo o dingote de urânio metálico e a escória de $\mathrm{MgF}_{2}$ é, então, desmontado, retirando-se os produtos obtidos. A superfície do dingote é limpada mecanicamente por meio de uma escova vibratória, retirando-se a escória aderida superficialmente. Após esta limpeza mecânica, o dingote é decapado em uma solução de ácido nítrico a 10\%, para, em seguida, ser lavado 
com água corrente e secado ao ar livre. A Figura 4 ilustra o processo de obtenção de urânio metálico.

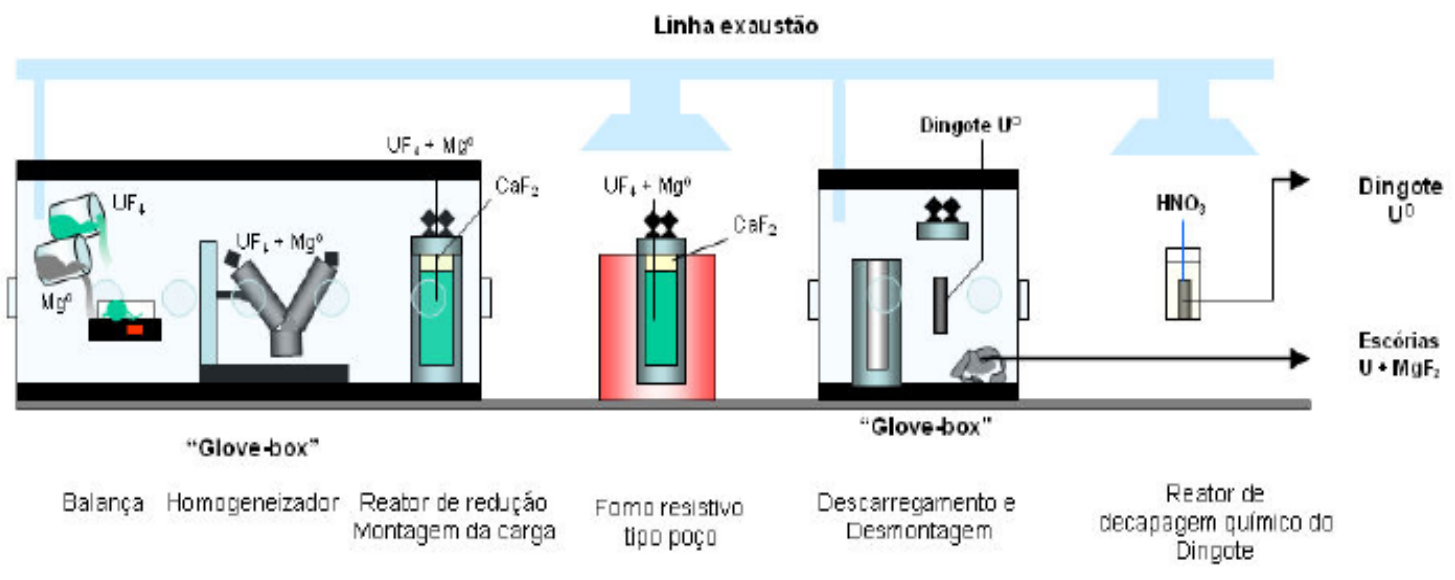

Figura 4 - Processo de fabricação de urânio metálico.

Para a preparação da carga de fusão do $\bigcup_{3} \mathrm{Si}_{2}$, as massas de grânulos de $\mathrm{Si}^{0}$ e pedaços de $\mathrm{U}^{0}$ devem ser pesados na proporção desejada. A fusão é realizada em forno de indução equipado com um sistema de vácuo e controle de atmosfera. A carga é preparada colocando-se os pedaços de $U^{0}$ num cadinho de zircônia. $\mathrm{O} \mathrm{Si}^{0}$ é acondicionado entre os pedaços de $\mathrm{U}^{0}$. Quando o cadinho é preenchido, o forno é fechado e evacuado e, posteriormente, preenchido com argônio até que seja atingida a pressão de 500 mbar. Depois que a carga é fundida, o forno é desligado e o banho é lingotado numa lingoteira de cobre. $O$ lingote obtido na fusão é retirado do cadinho e separado da escória. A Figura 5 ilustra o processo de obtenção do siliceto de urânio.

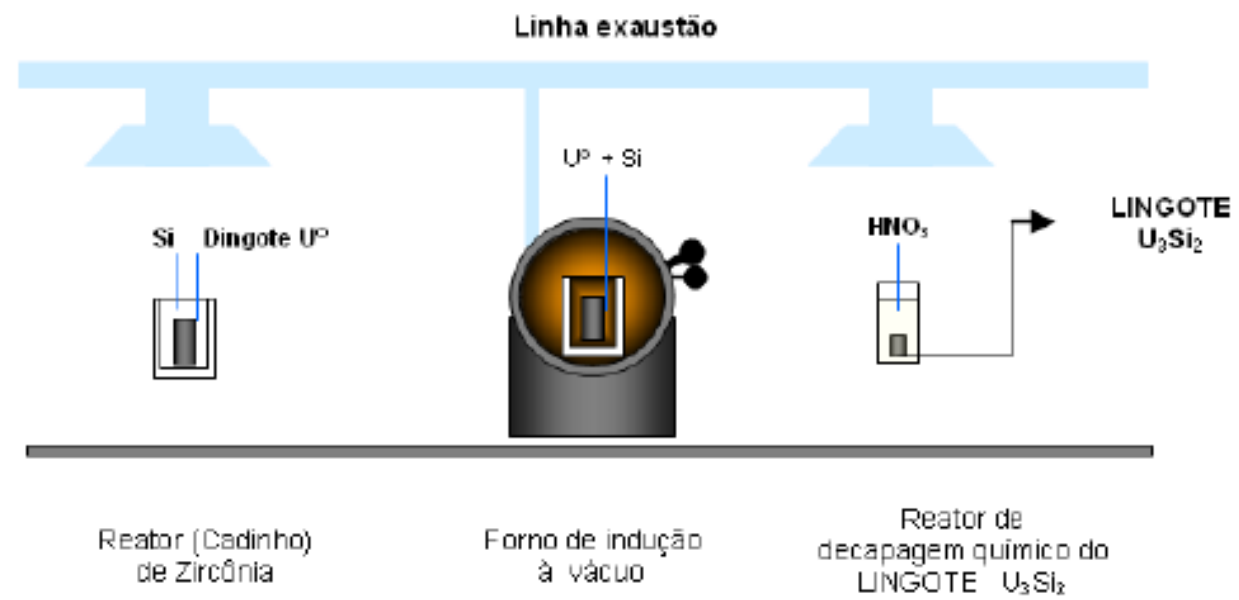

Figura 5 - Processo de fabricação de siliceto de urânio. 
Os lingotes são transferidos para uma caixa de luvas com atmosfera inerte, de argônio, já que os compostos são pirofóricos. A liga obtida é frágil, permitindo que a cominuição seja realizada manualmente. No interior da caixa de luvas, o material é submetido à moagem preliminar, obtendo-se grânulos menores de $4 \mathrm{~mm}$ com a menor fração de finos $(<44 \mu \mathrm{m})$ possível. Uma vez realizada a moagem preliminar, o material é colocado diretamente sobre um conjunto de peneiras, sendo, logo depois, peneirado manualmente. O conjunto de peneiras compreende uma peneira grosseira de abertura $4 \mathrm{~mm}$, uma peneira fina de abertura $150 \mu \mathrm{m}$ e um fundo. Os grânulos de diâmetro superior a $4 \mathrm{~mm}$ são novamente triturados. Os grânulos entre 4 mm e 150 m são coletados para a moagem fina e as partículas menores do que $150 \mu \mathrm{m}$ são separadas para posterior classificação granulométrica.

A moagem do material obtido a partir da moagem preliminar é também realizada manualmente. O material coletado durante a moagem preliminar, entre $4 \mathrm{~mm}$ e $150 \mu \mathrm{m}$, e o superior a $150 \mu \mathrm{m}$, proveniente do peneiramento (descrito a seguir), é processado nesta etapa. A moagem é realizada cuidadosamente, com peneiramentos intermediários, para classificação do pó na faixa 150 até 44 $\mu \mathrm{m}$. É permitida uma fração de finos (abaixo de $44 \mu \mathrm{m}$ ) máxima de $20 \%$ em peso. A fração acima da especificação é recolhida num recipiente, sendo enviada novamente para o sistema de moagem final. A fração na faixa especificada (entre $150 \mu \mathrm{m}$ e $44 \mu \mathrm{m}$ ) é recolhida e armazenada separadamente da fração fina (<44 $\mu \mathrm{m})$. A caixa de luvas contém no seu interior uma máquina de peneiramento vibratório, a qual efetua a separação de três frações granulométricas: uma maior do que $150 \mu \mathrm{m}$, outra entre 150 e $44 \mu \mathrm{m}$ e, a última, menor do que $44 \mu \mathrm{m}$. A composição do lote de pó de $\bigcup_{3} \mathrm{Si}_{2}$ é ajustada para um máximo de teor de finos de $20 \%$ em peso (que é o máximo especificado).

A próxima etapa do processo é a fabricação dos núcleos das placas combustíveis, os quais contém o material físsil, o $\bigcup_{3} \mathrm{Si}_{2}$. Esse núcleo é obtido por meio de técnicas de metalurgia do pó e é denominado briquete - compostos de cermets, compósitos cerâmico-metálicos, com pó de $U_{3} \mathrm{Si}_{2}$ enriquecido a $20 \%$ no isótopo ${ }^{235} \mathrm{U}$ (material combustível nuclear), em conjunto com pó de alumínio (material estrutural da matriz do núcleo). 
A massa e a composição do briquete são calculadas com base nos valores analisados de urânio total e enriquecimento isotópico do pó de $\mathrm{U}_{3} \mathrm{Si}_{2}$. $\mathrm{O}$ critério para o cálculo da massa do briquete é a quantidade do isótopo ${ }^{235} \mathrm{U}$ especificada para a placa combustível e o volume do briquete. As massas de pó combustível e pó de Al são determinadas separadamente e homogeneizadas em proporção que garanta a quantidade de ${ }^{235} \mathrm{U}$ especificada, distribuída uniformemente. Estas cargas de mistura são homogeneizadas e compactadas a frio. Após a compactação, os núcleos, ou briquetes, são desgaseificados por meio de um tratamento térmico a vácuo. Na Figura 6 , tem-se o processo de preparação dos briquetes e do conjunto.

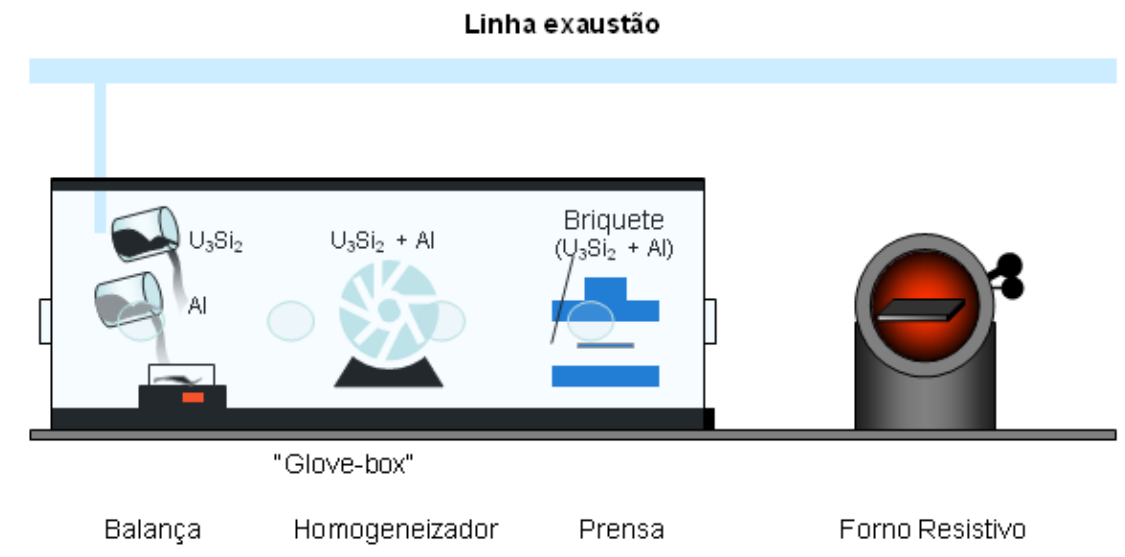

Figura 6 - Processo de preparação dos briquetes e desgaseificação.

As placas são fabricadas adotando-se a tradicional técnica de montagem "núcleo, moldura e revestimentos" e posterior laminação de um conjunto composto pelo núcleo (briquete), uma placa de moldura e duas de revestimento - técnica conhecida internacionalmente com o nome de "picture frame technique" $[7,8,22]$. Tal processo resulta na obtenção de uma placa combustível cujo núcleo é composto por dispersão de material físsil em alumínio - onde o urânio se encontra disperso, homogeneamente, em quantidades determinadas. Seu revestimento é totalmente lacrado. As características de cada pó, bem como as do revestimento e da moldura, devem ser compatíveis para um bom caldeamento na laminação, boa configuração geométrica e boa homogeneidade do núcleo, além de bom desempenho sob irradiação [22]. 
Obtém-se, assim, após a laminação, uma placa contendo no seu interior o núcleo combustível totalmente isolado do meio ambiente, por meio do perfeito caldeamento entre o núcleo e a moldura com as placas de revestimento.

As placas de moldura e revestimento são fabricadas a partir de placas de alumínio comerciais, da liga Al 6061. A Figura 7 (abaixo) ilustra a técnica de montagem "núcleo, moldura e revestimento" das placas combustíveis - os procedimentos do processo de fabricação são idênticos para os combustíveis à base de $\mathrm{U}_{3} \mathrm{Si}_{2}$ e $\mathrm{U}_{3} \mathrm{O}_{8}$ [23].

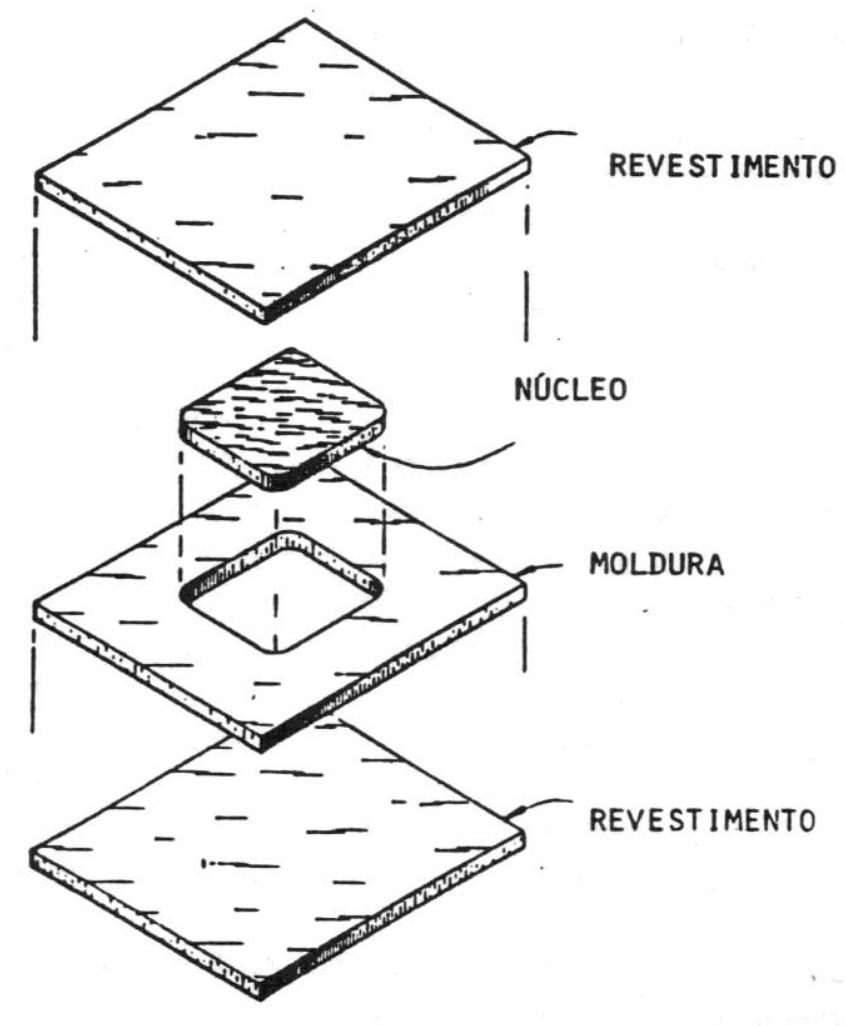

Figura 7 - Montagem das placas combustíveis [9].

Na montagem dos conjuntos, a placa de moldura é aquecida no forno de montagem à temperatura de $440^{\circ} \mathrm{C}$ e é encaixada no briquete frio apoiado numa placa de revestimento. Após o resfriamento da moldura, o briquete é fixado na em sua cavidade por interferência. A outra placa de revestimento é posicionada por cima. Este conjunto montado é preso numa morsa giratória na bancada de soldagem e tem sua borda soldada, fixando-se todos os 
componentes do conjunto [24]. A soldagem é do tipo TIG com argônio. Depositase um cordão contínuo de solda nas 4 arestas do conjunto, deixando-se livre as extremidades para escape do ar nos primeiros passes de laminação. A Figura 8 ilustra o procedimento de montagem dos conjuntos para laminação.
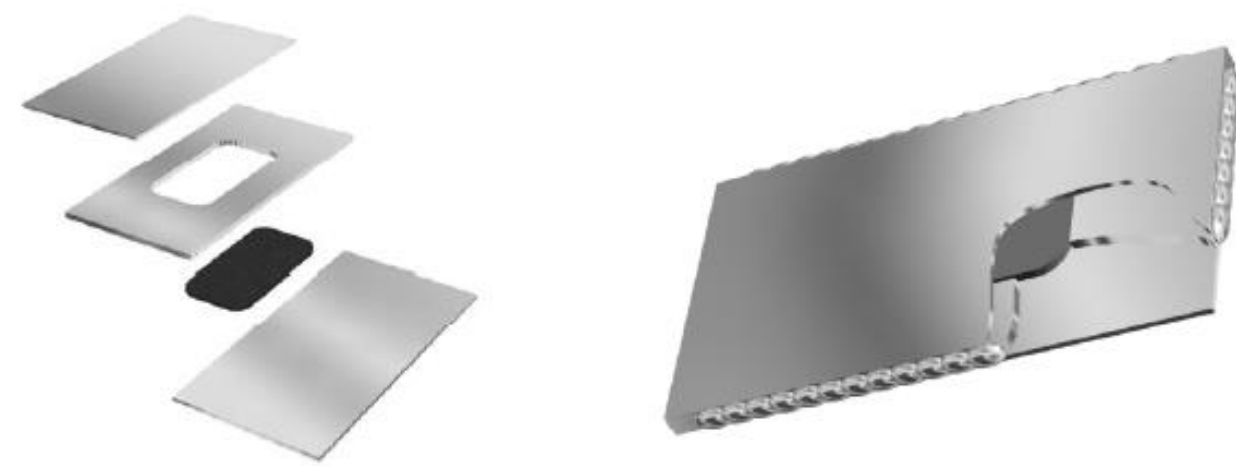

Figura 8 - Esquema ilustrativo da montagem do conjunto núcleo-moldura-revestimentos.

Os conjuntos soldados, devidamente identificados, são inseridos no forno de aquecimento de placas, a $440{ }^{\circ} \mathrm{C}$, por 60 minutos. Cada lote de laminação contém 8 conjuntos. A laminação a quente é realizada em vários passes conforme programa bem estabelecido. O projeto de passes não é variado além do limite de $0,1 \mathrm{~mm}$, para garantia do caldeamento e do controle e reprodutibilidade da deformação do núcleo. Entre cada passe a quente, os conjuntos são reaquecidos por 15 minutos.

A laminação a frio é realizada no mesmo laminador adotado na laminação a quente. Nesta operação, a espessura especificada é atingida com precisão. Durante a laminação a frio, o comprimento do núcleo da placa combustível é verificado, garantindo-se o atendimento da especificação de comprimento mínimo do núcleo e a espessura máxima da placa.

Após a laminação a frio, as placas combustíveis são pré-cortadas para facilitação do manuseio durante as operações subsequentes de aplanamento, radiografias, traçagem e corte final. As placas obtidas na laminação a frio apresentam suas superfícies bastante onduladas, sendo, por isso, necessária a citada operação de aplanamento. Esta é realizada utilizandose um aplainador de rolos, o qual consiste basicamente em um grupo de cilindros 
aplainadores e um sistema de ajuste destes cilindros. Apenas um passe é suficiente.

A próxima etapa é o corte final da placa combustível nas dimensões especificadas. Este corte é realizado em guilhotina utilizando-se uma traçagem baseada numa chapa radiográfica, obtida em sistema de radiografia industrial, onde o núcleo é perfeitamente localizado na placa combustível, traçando-se, a partir da posição do núcleo, linhas que orientarão o corte final. A seguir, as placas combustíveis são desengraxadas em acetona e decapadas numa solução de $\mathrm{NaOH}$ a $10 \%$ em peso, durante 1 minuto, a $60{ }^{\circ} \mathrm{C}$. Feito isto, passam pelas seguintes etapas: são lavadas em água corrente durante mais 1 minuto; neutralizadas em $\mathrm{HNO}_{3}$ a $40 \%$ em peso frio, mais uma vez por 1 minuto; lavadas novamente em água corrente pelo tempo de 5 minutos; lavadas em água corrente desmineralizada por 5 minutos ("spray"); lavadas por imersão em água desmineralizada quente e secadas manualmente com o auxílio de um secador de jato de ar quente.

A Figura 9 mostra um desenho da placa combustível, ilustrando seu núcleo. Como dito, após a laminação, ocorre o perfeito caldeamento entre todos os componentes do conjunto, obtendo-se uma peça única onde o núcleo está completamente vedado, encamisado por alumínio, o que impede o contato do material físsil com a água refrigerante do caroço do reator.

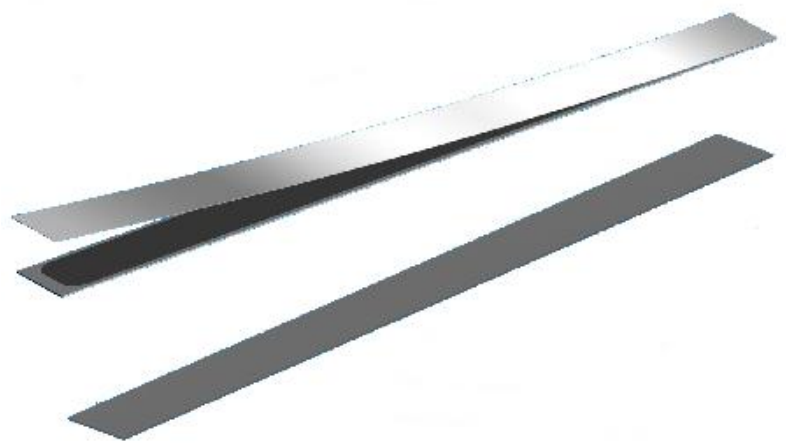

Figura 9 - Esquema ilustrativo da placa combustível laminada.

As placas combustíveis acabadas são caracterizadas dimensionalmente, obtendo-se seu comprimento, largura e espessura. Placas 
combustíveis que não atendem às especificações dimensionais são rejeitadas e encaminhadas para a recuperação do urânio contido.

A Figura 10, abaixo, apresenta a sequência de operações realizadas na fabricação das placas combustíveis.

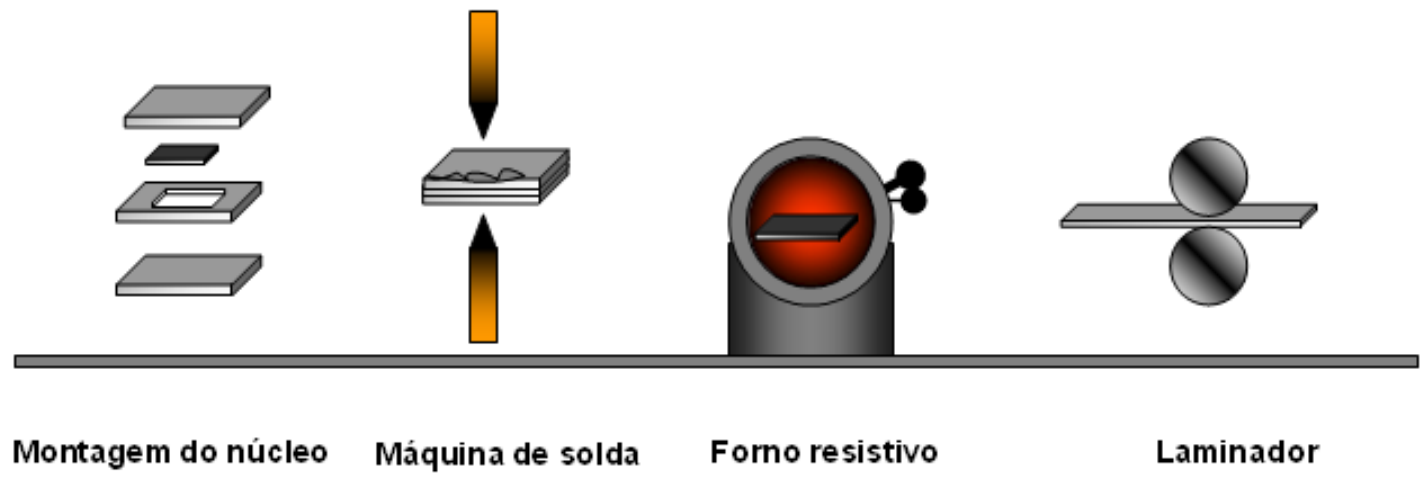

Figura 10 - Processo de preparação dos conjuntos e laminação.

Após o corte final, são obtidas duas novas radiografias. A primeira tem por objetivo a verificação do posicionamento do núcleo na placa combustível, assim como de seu comprimento e largura, utilizando-se negatoscópios. A segunda visa à verificação da homogeneidade da distribuição de urânio no núcleo e da sua integridade, além da presença de "pontos claros" e partículas físseis fora da zona do núcleo.

A cada 24 placas combustíveis produzidas (3 lotes de laminação), uma é submetida à retirada de medidas das espessuras do revestimento e do núcleo, as quais são especificadas. Essa medição é realizada na zona central do núcleo (3 amostras) e, principalmente, nas zonas terminais do núcleo, onde ocorrem os defeitos chamados "osso de cachorro" ("dog-boning") e "zona difusa" ("fish tail"). Nessas regiões, há uma diminuição nas espessuras dos revestimentos devido a esses defeitos. Caso a placa escolhida aleatoriamente apresente espessuras que não atendam às especificações, uma segunda placa combustível do lote de 24 é destruída e analisada. Se o defeito for comprovado, todos os 3 lotes de laminação são rejeitados. Essa análise é realizada por metalografia utilizando-se técnicas usuais e equipamentos específicos para este fim. Placas combustíveis rejeitadas nesta fase são encaminhadas para recuperação do urânio contido. 
A qualidade do caldeamento entre os componentes do conjunto original é verificada por meio de teste de dobramento, realizado em duas ocasiões: após o pré-corte e após o corte final. Neste teste, o material excedente oriundo do corte é extensivamente dobrado em $180^{\circ}$ num sentido, depois dobrado novamente no sentido oposto. Caso ocorram falhas de caldeamento, estas são facilmente detectadas por inspeção visual após o dobramento. Placas combustíveis rejeitadas nesta fase também são encaminhadas para recuperação do urânio contido.

\subsubsection{Processo de montagem do elemento combustível}

Os elementos combustíveis tipo placa são formados através da montagem de um conjunto de placas combustíveis igualmente espaçadas entre si, permitindo a passagem de um fluxo de água que serve como refrigerador e moderador $[25,26,27]$.

Dois tipos de elementos combustíveis são fabricados. O elemento combustível padrão é constituído de 18 placas combustíveis, 2 suportes laterais (direito e esquerdo), 1 bocal, 1 pino de sustentação e 8 parafusos. Já o segundo, o elemento combustível de controle, é composto por 12 placas combustíveis, 2 placas suportes laterais (direito e esquerdo), 2 placas-guia, 1 bocal, 1 cilindro amortecedor e 12 parafusos. Os elementos combustíveis têm suas características especificadas. Todos os seus componentes estruturais são adquiridos no mercado e fabricados de acordo com desenhos que são parte das especificações (os quais serão mostrados adiante).

A montagem do elemento combustível se inicia com a fixação das placas combustíveis por cravamento nas placas suportes laterais (direita e esquerda), o que pode ser feito devido às suas estrias. A Figura 11 mostra o arranjo da placa combustível nas placas suportes laterais [9]. 


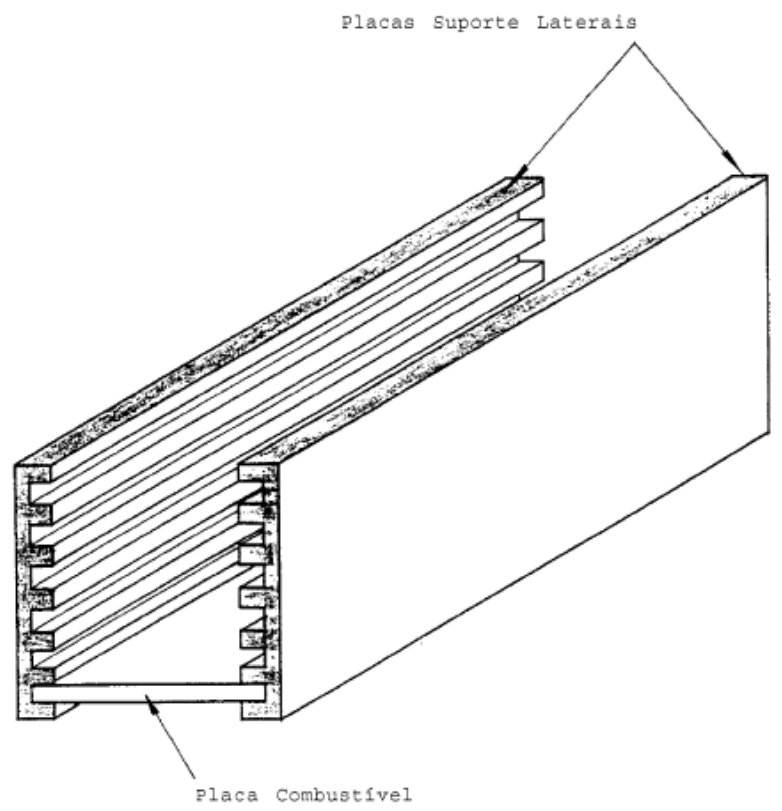

Figura 11 - Fixação da placa combustível nas placas suporte laterais [9].

Posteriormente, são fixados o bocal e o pino de sustentação, no caso do elemento combustível padrão, e o bocal e o cilindro amortecedor, no caso do elemento combustível de controle. Após a limpeza e a inspeção, os elementos combustíveis são embalados e armazenados até o transporte para o reator.

A Figura 12 apresenta as etapas do processo de montagem do elemento combustível.

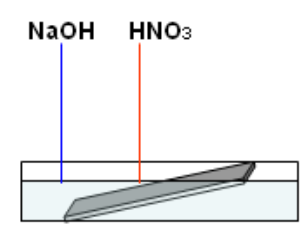

Reator de tratamento superficial

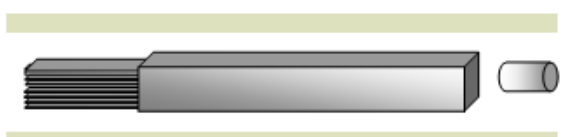

Máquina de Cravamento

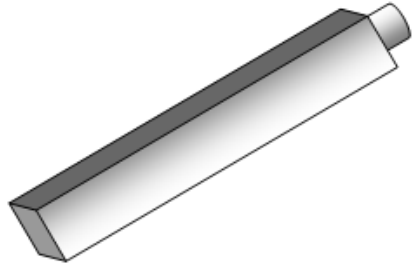

Elemento Combustivel

Figura 12 - Processo de montagem do elemento combustível.

Após a fixação das placas combustíveis nos suportes laterais (feitos de alumínio), é formado um "estojo". O próximo componente a ser instalado é o bocal, o qual tem múltiplas funções: serve de base de fixação das placas suportes, de apoio do elemento combustível na placa matriz do núcleo e de guia do fluido refrigerante através da placa matriz do núcleo. $O$ bocal de sustentação 
é fixado na extremidade inferior do estojo, montado por meio de parafusos; é alinhado ao estojo do elemento combustível através de uma operação de ajuste dimensional, utilizando-se mesa de desempeno e traçador de alturas. Os furos no bocal, que o fixarão nos suportes laterais, já se encontram usinados. A furação para a fixação do bocal nas placas combustíveis externas é usinada com o bocal já fixado nos suportes laterais, com o auxílio da fresadora, sendo preparadas roscas M6. Os parafusos utilizados são de alumínio e já devem estar devidamente limpos e qualificados. O aperto final é realizado após uma caracterização dimensional prévia, verificando-se o alinhamento do bocal no estojo. Caso o alinhamento não atenda à especificação, este é ajustado. No caso do elemento combustível de controle, o procedimento para a fixação do bocal e do cilindro amortecedor é o mesmo descrito acima.

O pino de sustentação é utilizado para a manipulação do elemento combustível padrão no interior da piscina do reator. Este pino tem a função de enrijecer o conjunto, fixando as placas laterais, e de apoio para o manuseio do elemento combustível nas inserções e retiradas do núcleo. Na extremidade superior do estojo montado, há dois furos em que o pino é fixado por meio de rebitamento, onde as extremidades deste pino, contendo cavidades, são deformadas por pressão com o auxílio da fresadora. No caso do elemento combustível de controle, este pino é substituído pelo cilindro amortecedor, que tem por finalidade o amortecimento da barra de controle ou segurança que opera no interior deste tipo de elemento combustível.

A Figura 13 ilustra o elemento combustível padrão e seus componentes. 


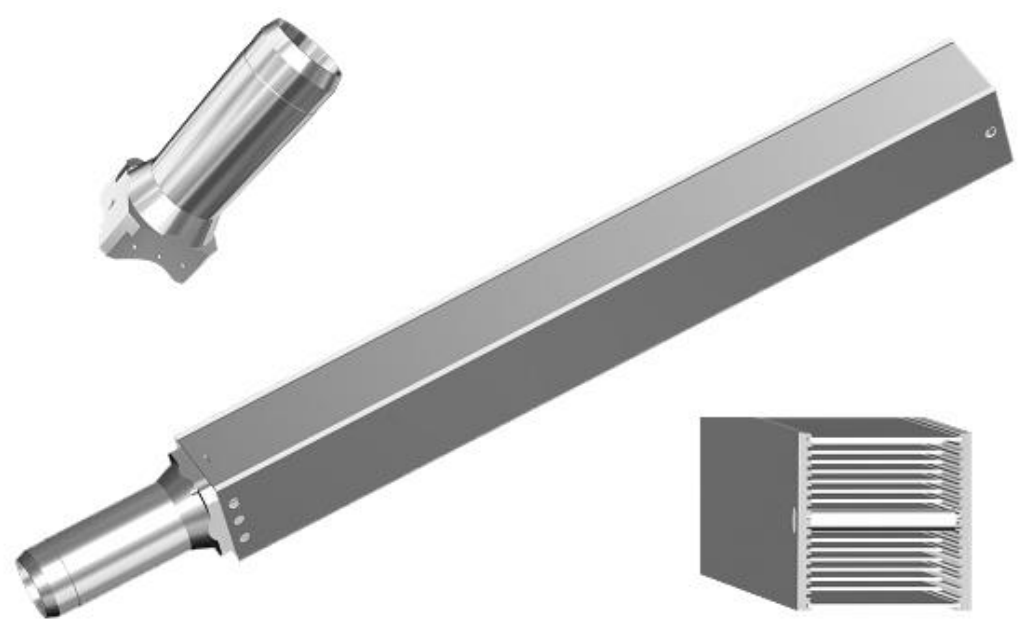

Figura 13 - Esquema ilustrativo do elemento combustível fabricado no IPEN.

Todos os componentes estruturais do elemento combustível - placas laterais, bocal de extremidade e pino de sustentação - são feitos de ligas de alumínio. Além disso, todos os componentes e o elemento combustível são fabricados de acordo com desenhos que, por sua vez, são parte das especificações.

A Figura 14 mostra um fluxograma simplificado das etapas do processo de fabricação dos elementos combustíveis tipo placa a base de dispersão [9]. 


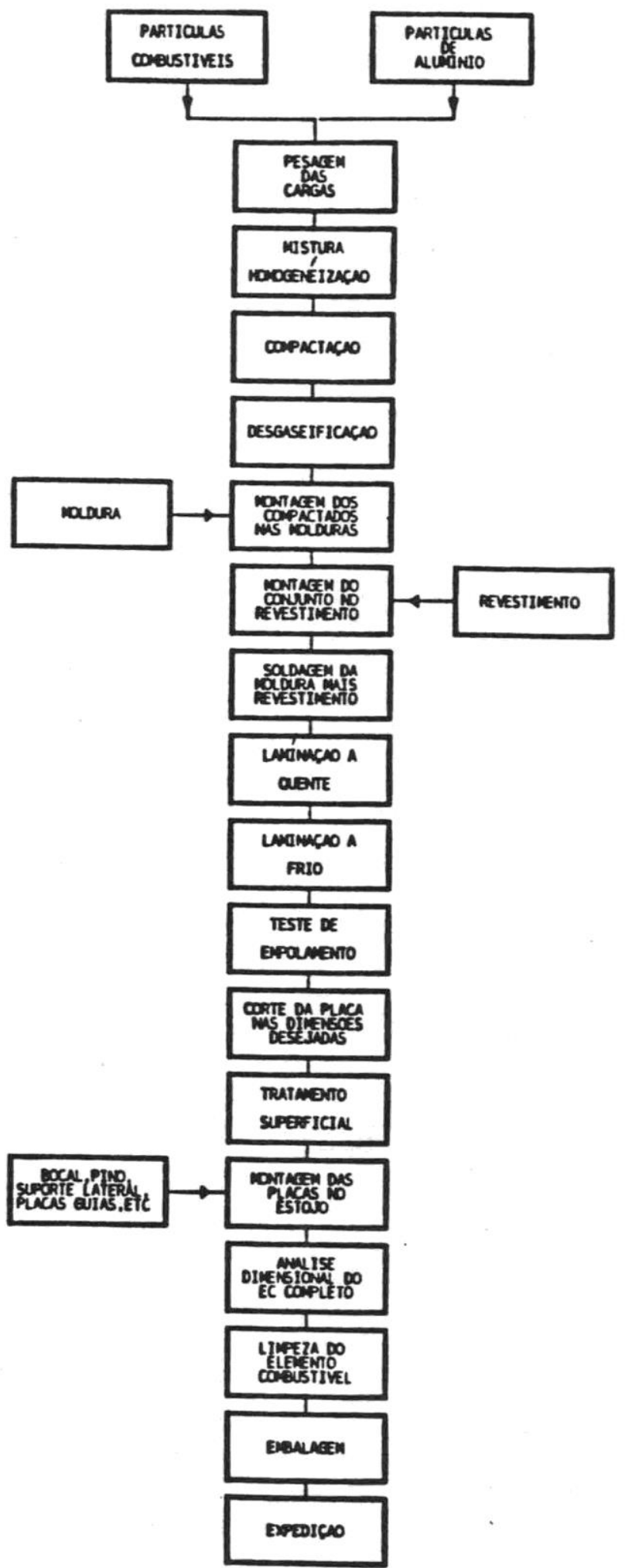

Figura 14 - Fluxograma simplificado das etapas de fabricação de elementos combustíveis tipo placa a base de dispersão [9]. 
No que tange aos testes de irradiação - definitivos para qualificação do combustível nuclear -, as principais variáveis que influenciam na fabricação das placas combustíveis tipo dispersão são [22,28]: diâmetro da partícula combustível; morfologia da partícula combustível; massa específica da partícula combustível; área de superfície específica da partícula combustível; e fração em volume combustível.

Uma vez qualificado, o elemento combustível é lavado em banho de álcool etílico e seco manualmente com o auxílio de um jato de ar quente. Após esta limpeza, é realizada uma inspeção visual, especialmente no interior dos canais de refrigeração, procurando detectar possíveis obstruções causadas por materiais estranhos.

Depois disso, como já mencionado, o combustível nuclear precisa ser qualificado e, para tanto, deve-se fazer análises por metalografia de suas espessuras de núcleos e revestimentos das placas combustíveis, a partir de técnicas que envolvem análise de imagens [29, 30]. Por conta disso, neste trabalho é sugerida uma forma automatizada e rápida para realizar esses processos de medições. 


\section{MATERIAIS E MÉTODOS}

Para que sejam determinadas as medidas de espessuras de núcleos e revestimentos de placas combustíveis, é necessário preparar as amostras (Processo 1) e, posteriormente, analisá-las metalograficamente em um software denominado Omnimet Enterprise (Processo 2). O primeiro processo é necessário toda vez que o experimento de medição de espessuras é realizado, seja pelo método atual ou pelo novo método proposto neste trabalho. O segundo processo é feito, atualmente, com a utilização de um microscópio óptico motorizado de luz refletida, sendo que a imagem capturada pelo mesmo é enviada ao software e analisada manualmente por um operador, o qual utiliza o software citado acima.

O novo método de medição de espessuras de núcleos e revestimentos de placas combustíveis, proposto neste trabalho, difere-se do atual pelo fato de obter as imagens a partir de Microscopia Eletrônica de Varredura (MEV) de elétrons retroespalhados e, em seguida, por ter sua análise realizada com a criação de um programa computacional, no mesmo software citado, que a faz de forma automatizada. É por conta deste fato que a obtenção dos resultados se torna mais rápida.

A figura abaixo (Figura 15) expõe um fluxograma simplificado para obtenção das referidas medidas, no qual se tem que, para a obtenção dos dados de espessuras, é necessário realizar os procedimentos 1 e 2 (o atual e 0 procedimento sugerido, respectivamente). 


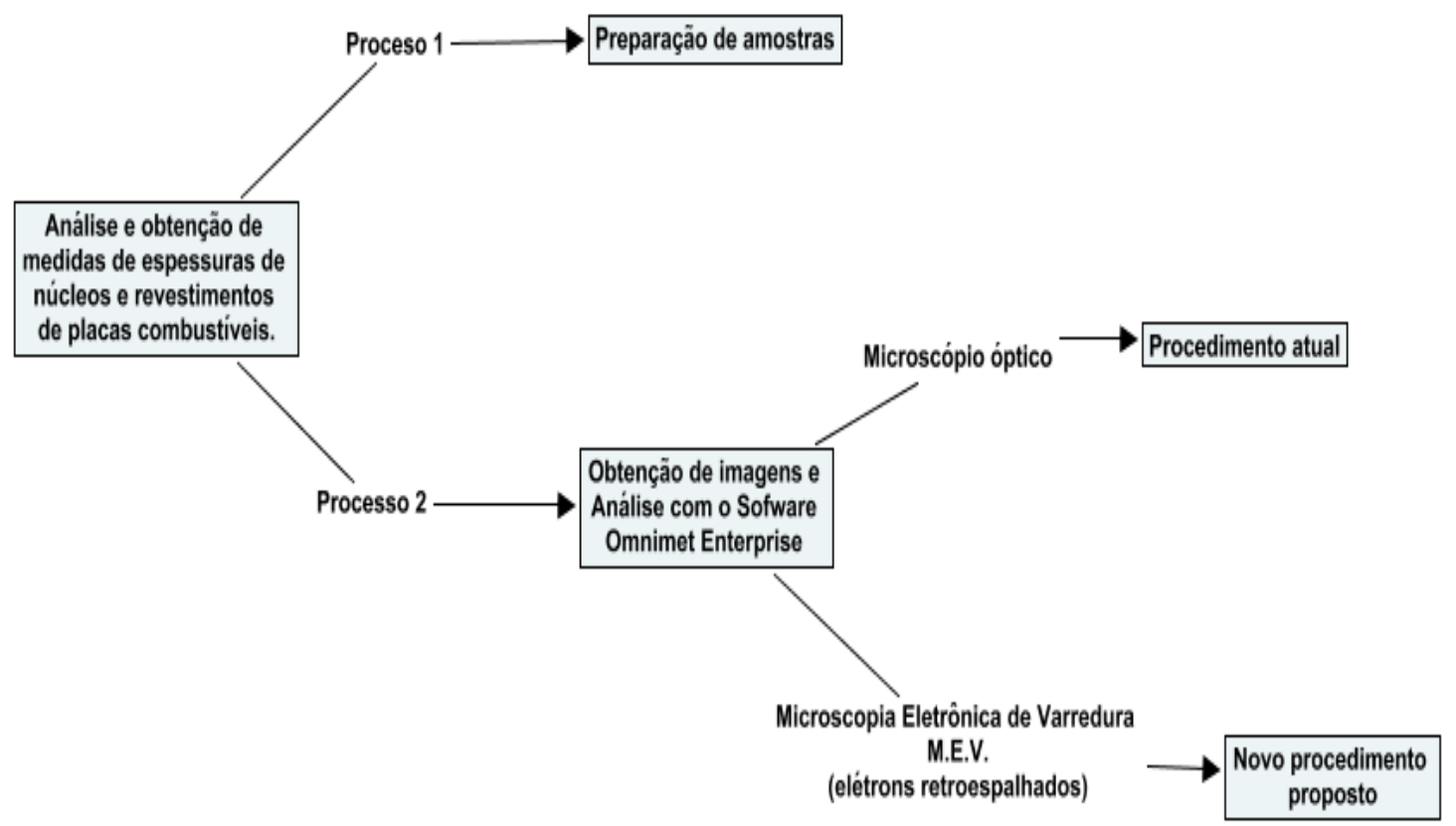

Figura 15 - Processo de medição de espessuras de núcleos e revestimentos de placas combustíveis.

Os tópicos seguintes descrevem os processos apresentados acima: preparação de amostras e método atual de medição das espessuras das placas combustíveis.

\subsection{Preparação das amostras para a análise Metalográfica}

A placa combustível destinada ao ensaio destrutivo de metalografia é recebida pelo Laboratório de Metalografia do CCN-IPEN, para as operações de pré-corte, corte, embutimento, lixamento e polimento. Abaixo, uma imagem (Figura 16) que mostra a placa combustível após ter sido submetida a alguns cortes para retirada das amostras.

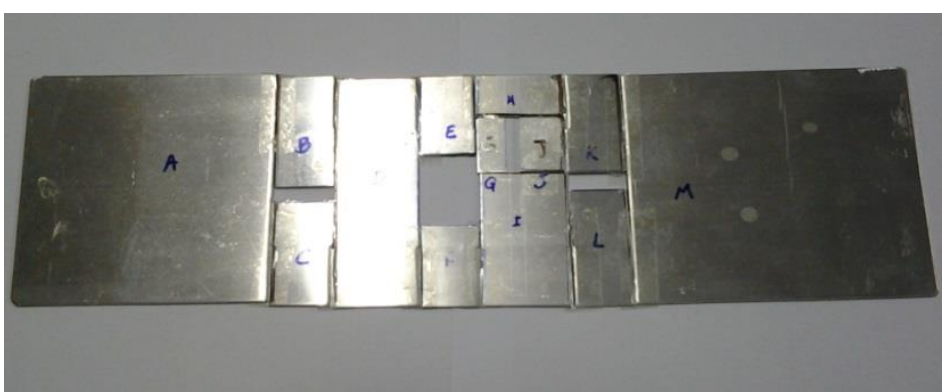

Figura 16 - Placa combustível cortada. 
Na placa combustível recebida, sete regiões, definidas por norma, são consideradas para análise, de acordo com as Figuras 17 e 18 apresentadas abaixo: TLID, TLIE, CTD, CTE, CL, TLSD e TLSE. Cada uma destas regiões é delimitada, no Laboratório de Metrologia, por três traços longitudinais e dois transversais, efetuados com riscador metálico.

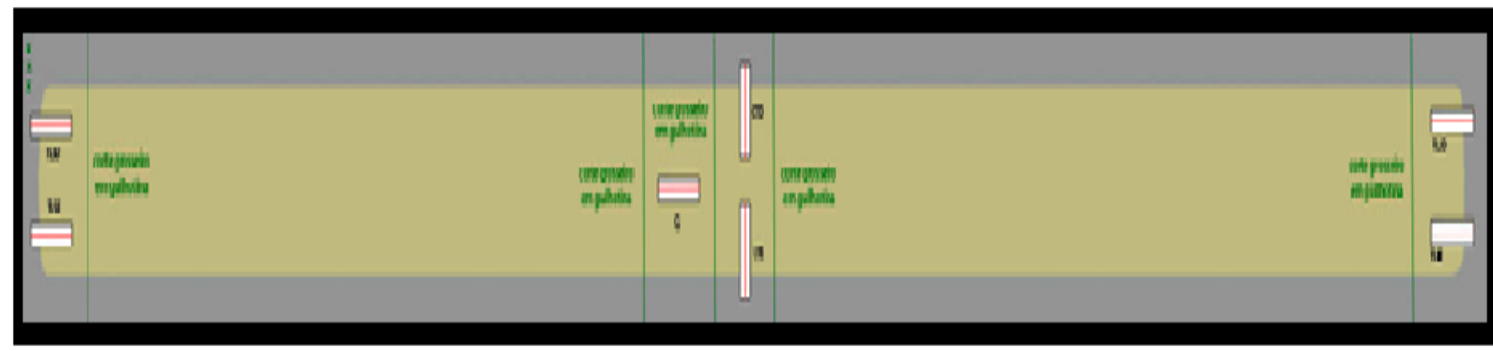

Figura 17 - Esquema de corte de regiões a serem analisadas para medidas de espessura de núcleo e revestimento de placas combustíveis.
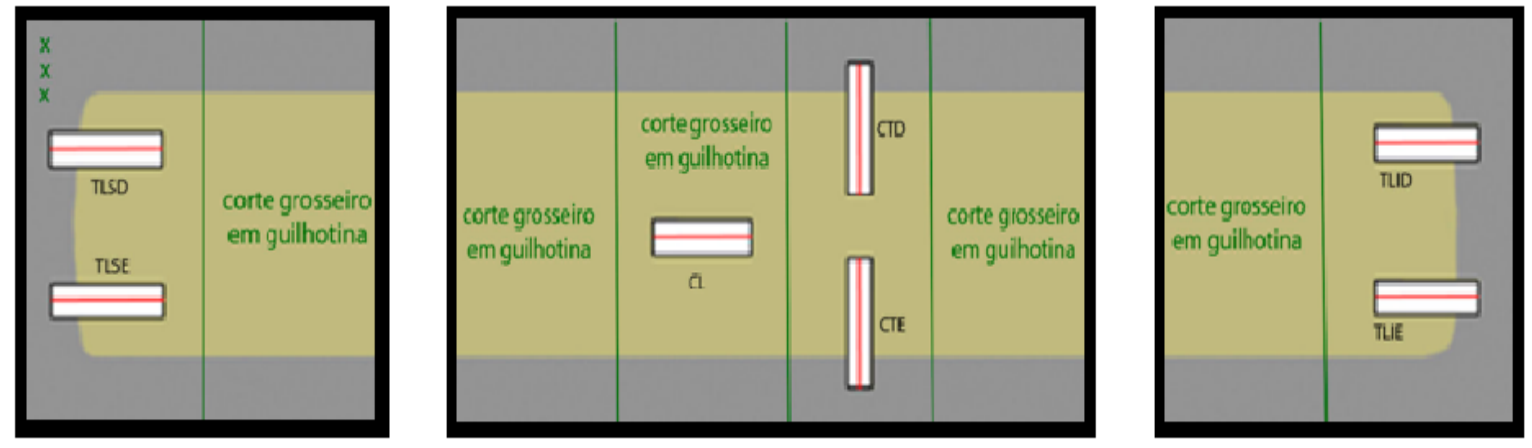

Figura 18 - Detalhes das sete regiões para visualização de pré-corte em guilhotina e corte em cortadeira com disco diamantado.

Os traços externos que delimitam cada uma destas sete regiões são feitos com caneta azul (as mesmas utilizadas em transparências de projetores de slides), e o traço longitudinal interno com caneta vermelha, para facilitar as operações de pré-corte e corte das amostras da placa combustível.

Adiante, será feita a descrição de cada uma das etapas de preparação das amostras para posterior análise.

\subsubsection{Operações de "pré-corte" e "corte" da placa combustível}

É realizado um pré-corte, ou corte grosseiro, sobre as linhas verdes (indicadas acima nas Figuras 17 e 18) da placa combustível, ao redor das sete 
regiões demarcadas a caneta, deixando-se de 1 a $2 \mathrm{~cm}$ a mais em torno da demarcação de cada região. Isto se faz necessário porque a guilhotina, antes de cortar a amostra, deforma-a enquanto é fixada. O pré-corte é feito utilizando-se uma guilhotina manual, preservando as amostras representativas das sete regiões anteriormente descritas. A figura seguinte (Figura 19) apresenta fotografia da guilhotina responsável pelo pré-corte.

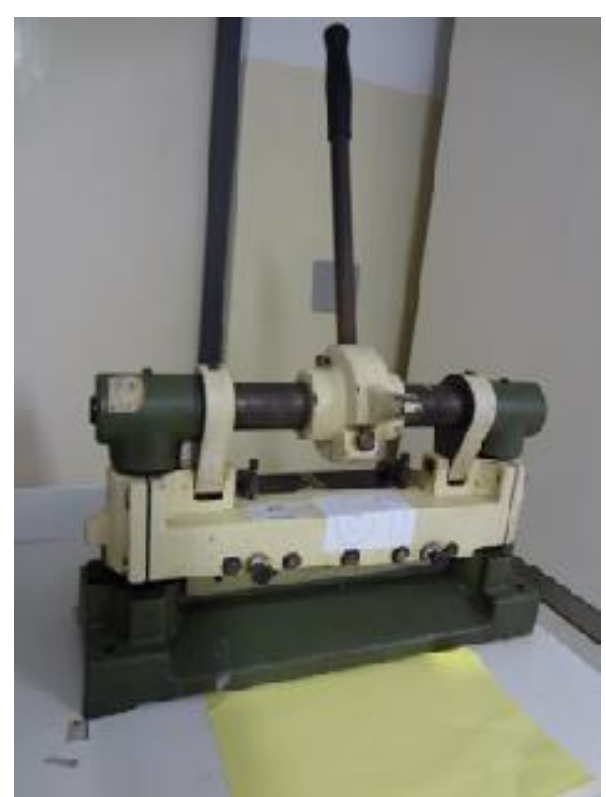

Figura 19 - Guilhotina utilizada no pré-corte de placas combustíveis.

Para que o corte final seja realizado com precisão, utiliza-se uma cortadeira com disco diamantado Isomet (Figura 20). Os retalhos resultantes do pré-corte são posicionados convenientemente no mecanismo de fixação da cortadeira, fora da zona demarcada à caneta azul, no excedente métrico reservado para este fim. 


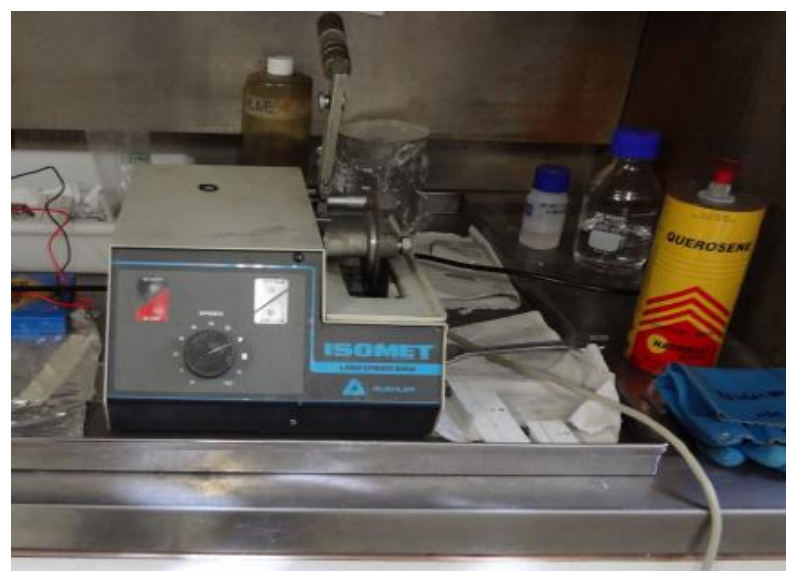

Figura 20 - Cortadeira Isomet com disco diamantado.

O disco diamantado, do qual a cortadeira é provida, é um detalhe que garante um corte preciso das amostras, adequado às operações posteriores. Este disco é conduzido na presença de um fluido de corte específico, que refrigera e lubrifica a amostra (neste trabalho foi utilizado o querosene).

Cada uma das sete amostras é recortada nas linhas azuis demarcadas e, posteriormente, cortada sobre o traço evidenciado pela linha vermelha, de modo a ser dividida em duas metades longitudinais, como mostra a Figura 21 abaixo.

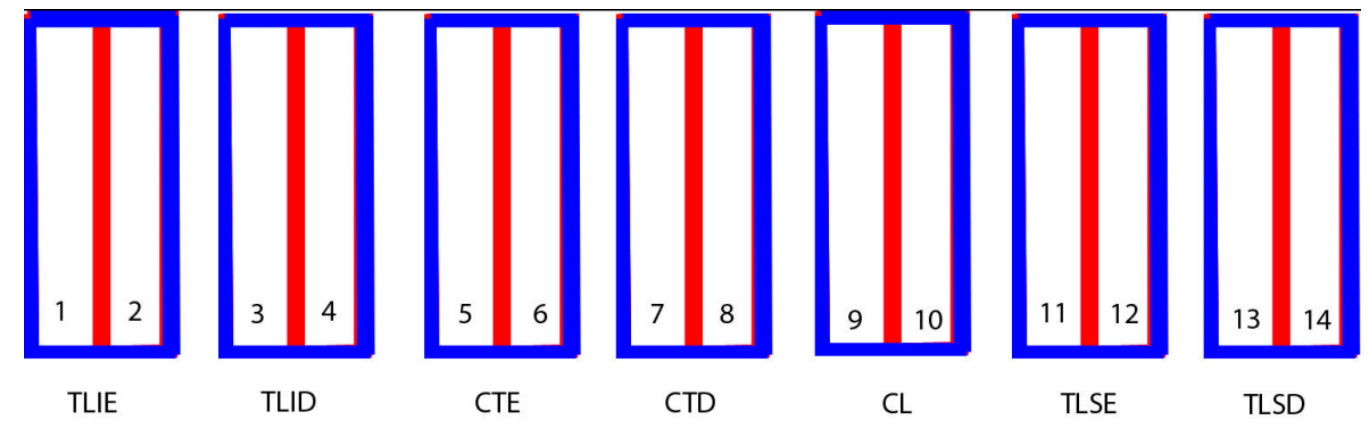

Figura 21 - Mapa para "embutimento" e reserva para contraprovas de amostras de placas combustíveis.

Feito isso, o próximo passo para continuação do preparo da amostra é o processo de embutimento, o qual será descrito adiante. 


\subsubsection{Operação de "embutimento"}

Nesta etapa de embutimento - quando as peças cortadas são colocadas em moldes cilíndricos de plásticos -, são utilizadas as metades situadas à esquerda do corte descrito anteriormente (Figura 21), ou seja, as ímpares, numeradas de 1 a 13. Já as outras metades, as pares, de 2 a 14, são guardadas para alguma eventual contraprova.

Cada uma das amostras de 1 a 13, devidamente numerada e identificada, é presa em um grampo metálico (o que garante a ortogonalidade de seu eixo transversal) e, em seguida, colocada no molde de plástico, onde é centralizada com o auxílio de uma pinça (Figura 22).

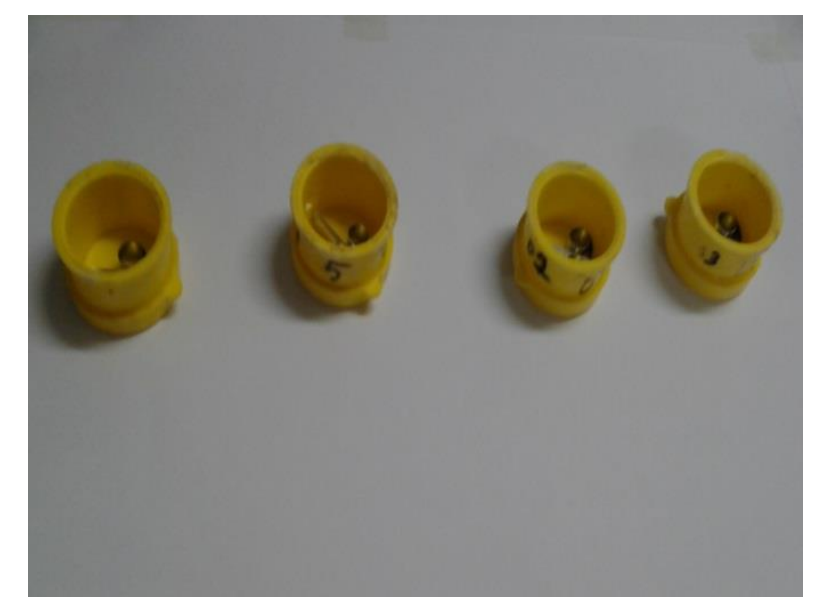

Figura 22 - Amostras, com grampos, no molde cilíndrico de plástico.

Tendo sido a amostra centralizada manualmente dentro do molde plástico, é preparada uma mistura (Figura 23), na proporção de duas partes de pó de resina acrílica (Acrifíx ou similar) para uma parte de seu catalisador líquido. 


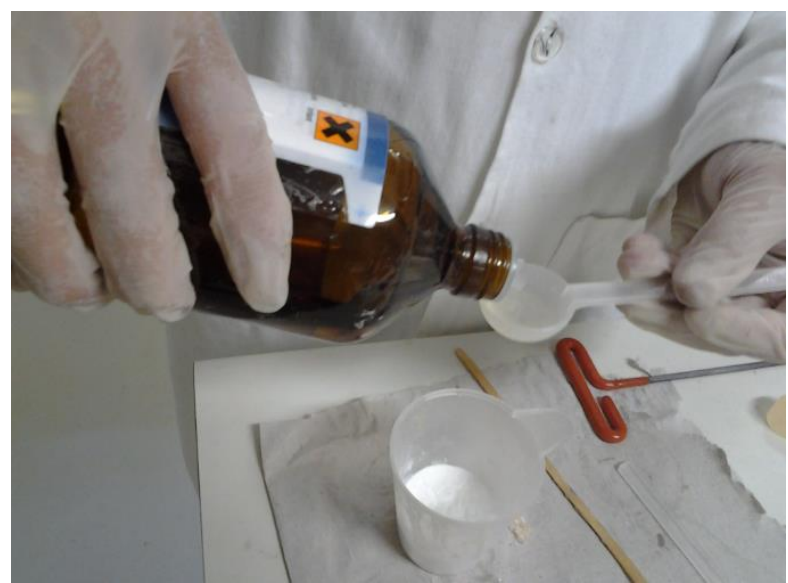

Figura 23 - Preparação da resina para embutimento.

A mistura da resina descrita é vertida cuidadosamente nos sete moldes plásticos de embutimento (Figura 24), os quais comportam as amostras cortadas, e é aguardado o tempo de cura de tal resina - aproximadamente 4 horas.

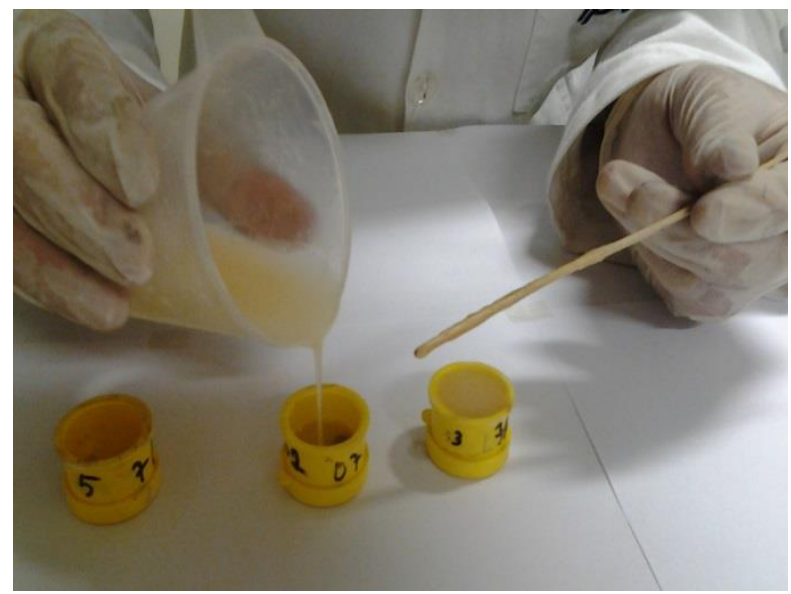

Figura 24 - Embutimento com resina no molde cilíndrico.

Depois de curada a resina, cada uma das sete amostras é retirada do molde cilíndrico de plástico. Abaixo, na Figura 25, encontram-se algumas amostras cuja resina já foi curada. 


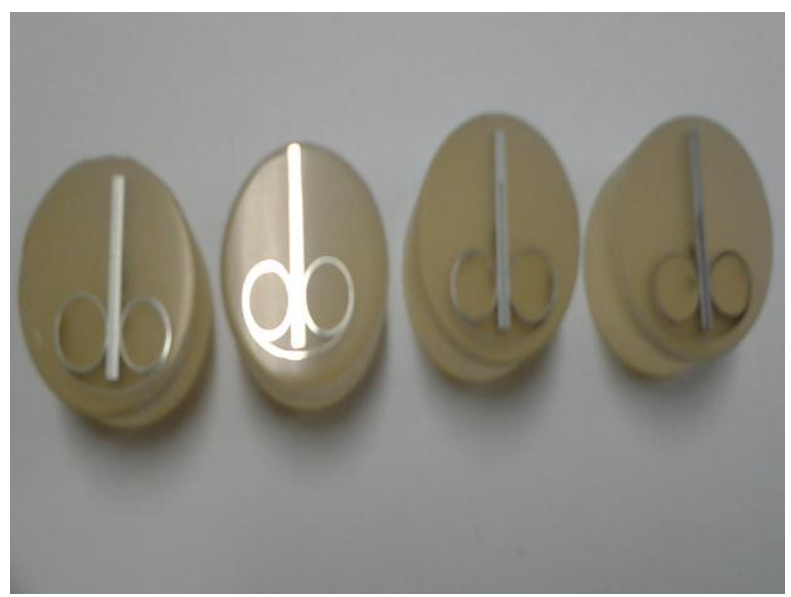

Figura 25 - Amostras desmoldadas.

As amostras, já embutidas, são identificadas em sua lateral com caneta gravadora vibratória, informando-se a numeração da placa e região da mesma (1 a 13), como mostra a Figura 26 a seguir.

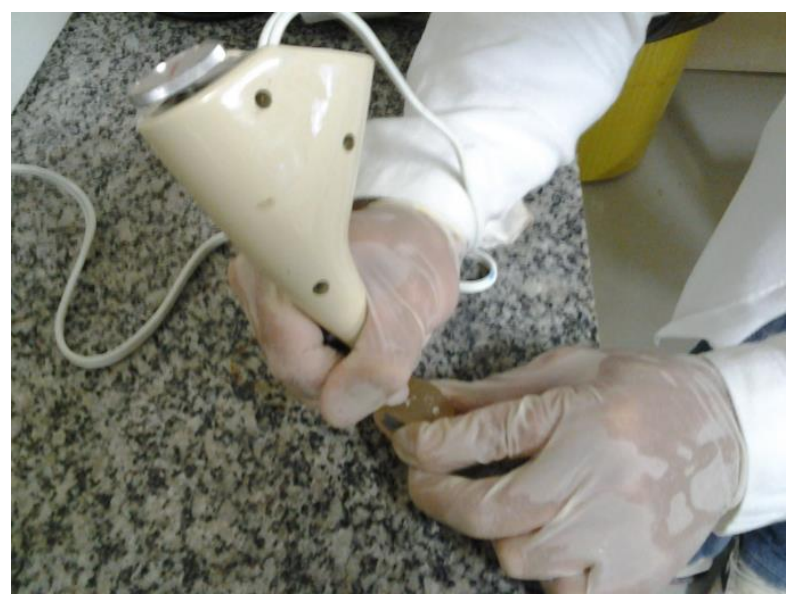

Figura 26 - Marcação das amostras.

O centro da face oposta à que será analisada é furado com furadeira e broca de 1,5 mm, a uma profundidade de $8 \mathrm{~mm}$. Este orifício é empregado para polimento final das amostras na Politriz Especial Minimet, com sílica coloidal (que será apresentada no tópico 4.1.4).

\subsubsection{Operação de "lixamento"}

O lixamento das amostras é realizado com o objetivo de eliminar excessos indesejados, oriundos do corte com disco diamantado, além de preparar sua superfície para as etapas mais refinadas de polimento. As sete 
amostras são fixadas em um porta-amostras específico e este é levado a um nivelador (Figura 27), de forma que o eixo de simetria transversal de cada amostra embutida fique perpendicular ao raio do porta-amostras.

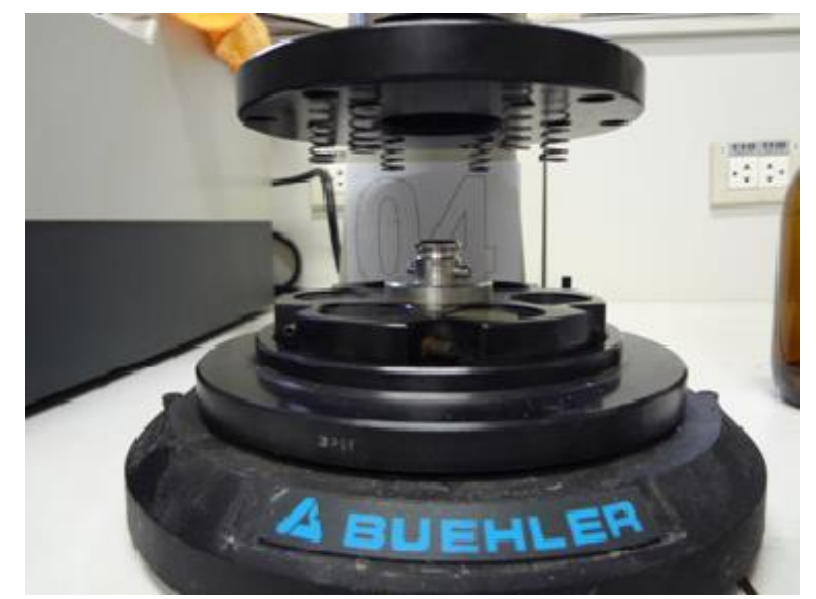

Figura 27 - Nivelador de amostras.

As sete amostras são lixadas em politriz semiautomática (Figura 28) em lixa P400, utilizando-se carga de uma libra por amostra, durante 60 segundos, com o prato girando à frequência de 110 rpm.

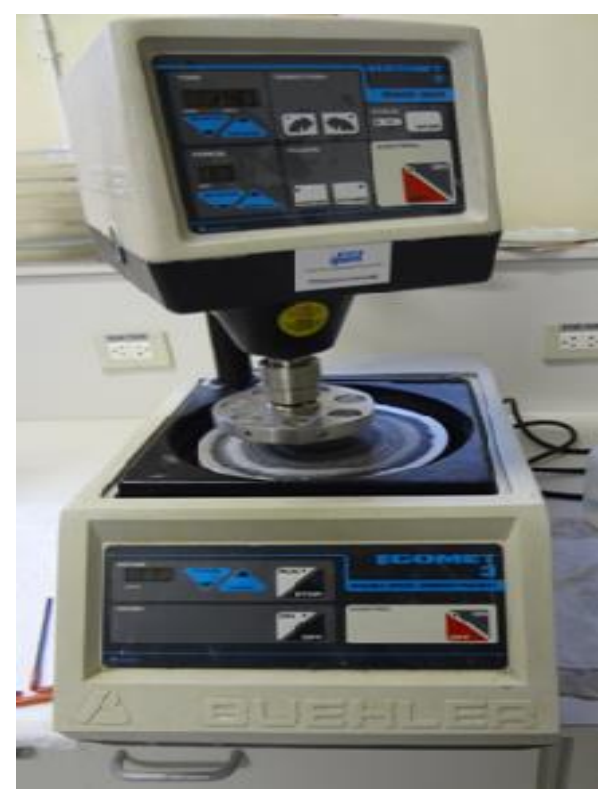

Figura 28 - Politriz semiautomática, para lixamento, com velocidade de rotação e carga reguláveis. 
Após o lixamento, todo o conjunto montado é lavado em água corrente, usando-se algodão e detergente; as sete amostras são secadas ainda no porta-amostras, com algodão embebido em álcool de pureza absoluta e secador. O procedimento é repetido utilizando-se lixas $P 1200$ e P2500, nesta ordem, as quais são mostradas na Figura 29.

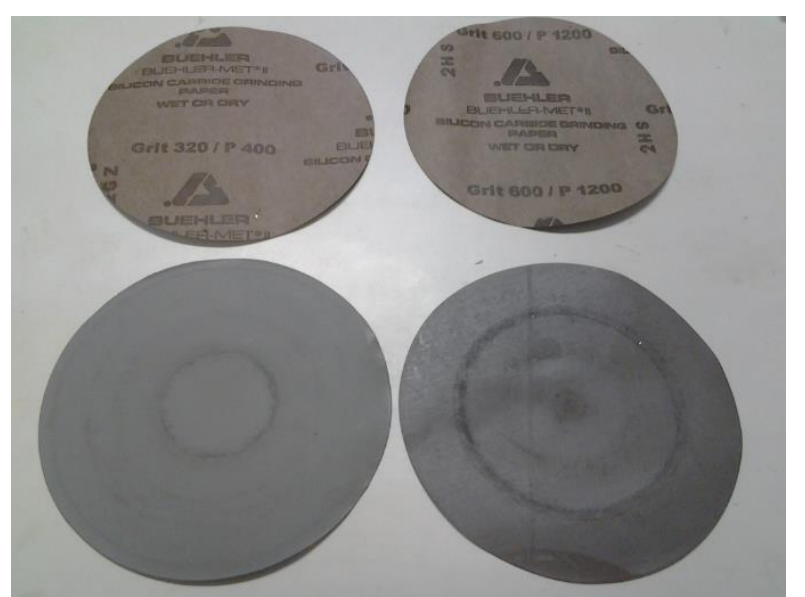

Figura 29 - Lixas empregadas na operação de lixamento.

\subsubsection{Operação de "polimento"}

Sem retirar as sete amostras do porta-amostras, continua-se o seu polimento em Politriz semiautomática utilizando carga de uma libra por amostra, durante 10 minutos, à $110 \mathrm{rpm}$. O pano de polimento utilizado é o Allied Tech Cloth, levemente embebido em suspensão diamantada de $6 \mu \mathrm{m}$. O portaamostras é retirado da Politriz e todo o conjunto montado é novamente lavado em água corrente, com algodão e detergente, secando as sete amostras, ainda no porta-amostras, com algodão embebido em álcool de pureza absoluta, e secador.

O procedimento descrito acima é repetido utilizando-se carga de 1,5 libra por amostra, durante 15 minutos, a $110 \mathrm{rpm}$. O pano de polimento empregado é o Allied White Label, embebido em suspensão diamantada de 3 $\mu m$. O porta-amostras é retirado da Politriz e todo o conjunto montado é lavado e secado da mesma forma como descrito no parágrafo anterior.

O polimento final é realizado individualmente, em Politriz Minimet (Figura 30), em cada amostra, após sua remoção do porta-amostras. 


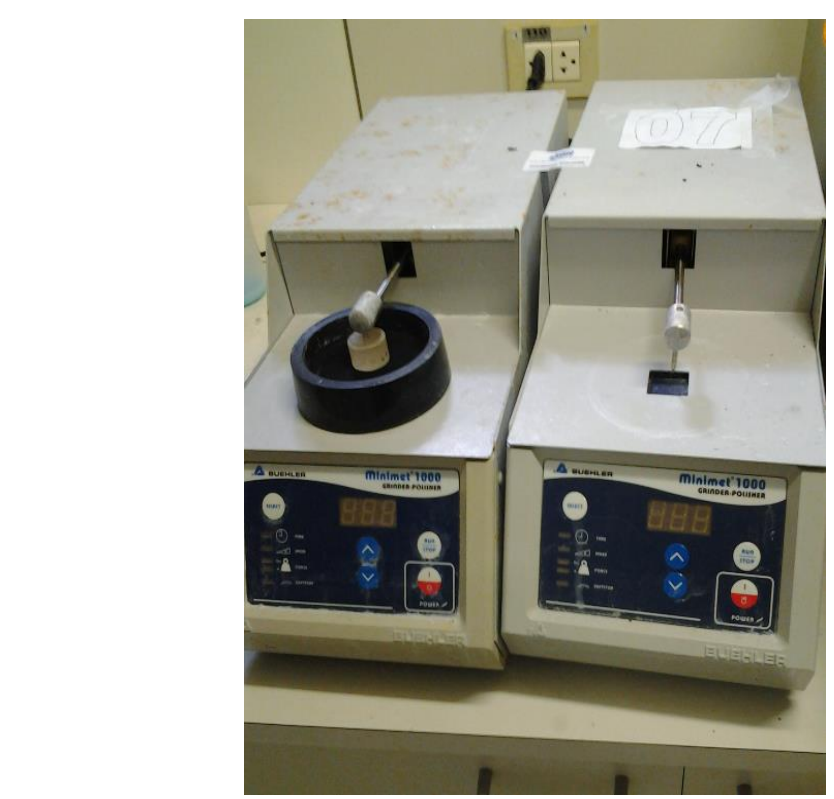

Figura 30 - Politriz Minimet para polimento com sílica coloidal.

Este polimento contempla um movimento de giro aleatório, em um recipiente plástico, semelhante a uma vasilha, dentro do qual é fixado um disco de acrílico encaixado em sua base. Neste disco é colado o pano Microcloth, adequado ao uso com sílica coloidal de 0,02 $\mu \mathrm{m}$. A amostra é fixada na Politriz através do pino da mesma, que se encaixa no furo feito na amostra embutida, conforme descrito anteriormente.

Utiliza-se carga de 1 libra, com velocidade de polimento de 10 rpm e faz-se observações parciais a cada 5 minutos. É verificada a presença de riscos remanescentes, bem como a desejada ausência de arrancamento de partículas de $\mathrm{U}_{3} \mathrm{Si}_{2}$.

Ao final deste procedimento, todas as amostras devem estar livres de quaisquer riscos e perfeitamente limpas, encontrando-se, então, prontas para serem caracterizadas, submetidas aos demais processos: captura e análise de imagens.

\subsection{Atual processo de medição de espessuras de núcleos e revestimentos de placas combustíveis}

Para a caracterização dimensional interna da placa combustível, utiliza-se um analisador de imagens de marca Buehler (Figura 31), com o software Omnimet Enterprise. O analisador é composto por um microscópio óptico de luz refletida, motorizado, com platina invertida e movimentação desta 
nos eixos $X, Y$ e $Z$. A imagem capturada pelo microscópio ("frame") é digitalizada por uma câmera e enviada a uma placa de captura que compõe a CPU do equipamento. O software mencionado trabalha as imagens digitalizadas e é responsável por fornecer as informações especificadas para a placa combustível - espessuras de núcleos e revestimentos.

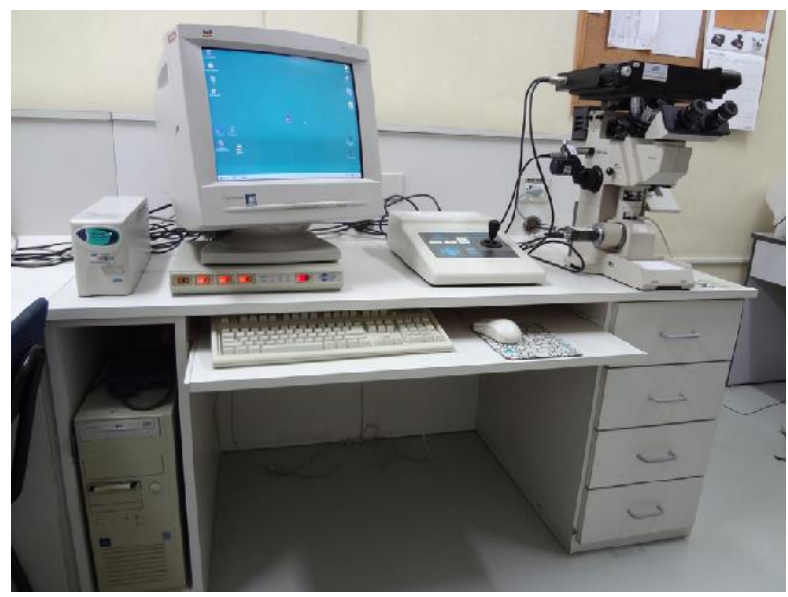

Figura 31 - Analisador de Imagens Buehler, Omnimet Enterprise, com Microscópio Olympus PME3, Joystick para movimentação da Platina invertida e CPU dedicada.

Depois de capturada a imagem, são feitas as medidas de espessuras de núcleo e revestimentos da mesma. Cada imagem capturada, ou frame, corresponde a um pedaço da amostra, de forma que é preciso percorrê-la com o Joystick até que sua totalidade seja medida. Na imagem capturada, a espessura da amostra (largura da imagem na tela) é visualizada inteiramente. A Figura 32 traz uma imagem capturada pelo microscópio óptico, a qual será submetida as medições.

Cada uma das sete amostras preparadas metalograficamente é posicionada sobre a platina e, com o auxílio do Joystick, percorre-se trecho a trecho das porções das amostras, após cada medição, em todo seu comprimento. 


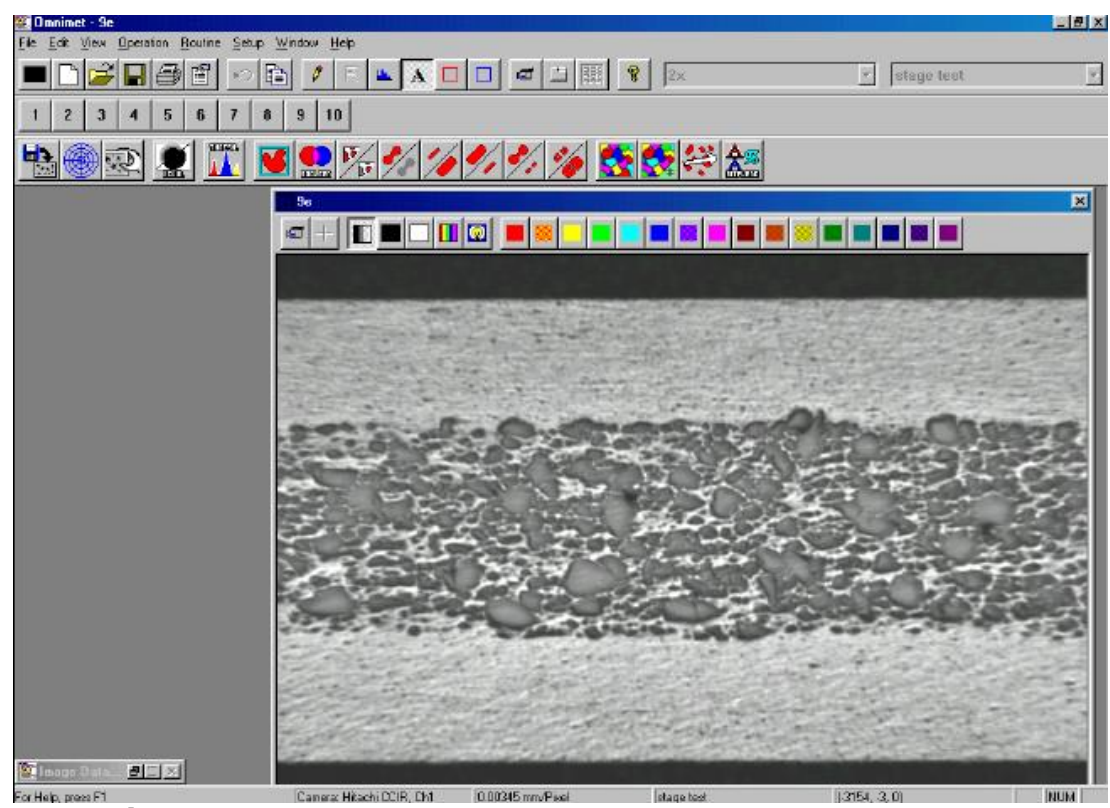

Figura 32 - Típica imagem obtida no analisador de Imagens Buehler (Omnimet Enterprise) capturada no Microscópio Olympus PME3.

Para o processo de medição atual, são traçadas duas linhas na imagem, uma na extremidade exterior do revestimento e outra na extremidade inferior, tangenciando a partícula mais externa superior (Figura 33). O valor obtido pelo software para a distância entre as duas linhas é anotado (o documento em que se fazem tais anotações será mostrado no próximo tópico do trabalho); este número representa o valor mínimo de revestimento para esta porção da amostra - aparente na largura da tela. O mesmo procedimento é realizado para a determinação das espessuras do núcleo e do revestimento inferior. 


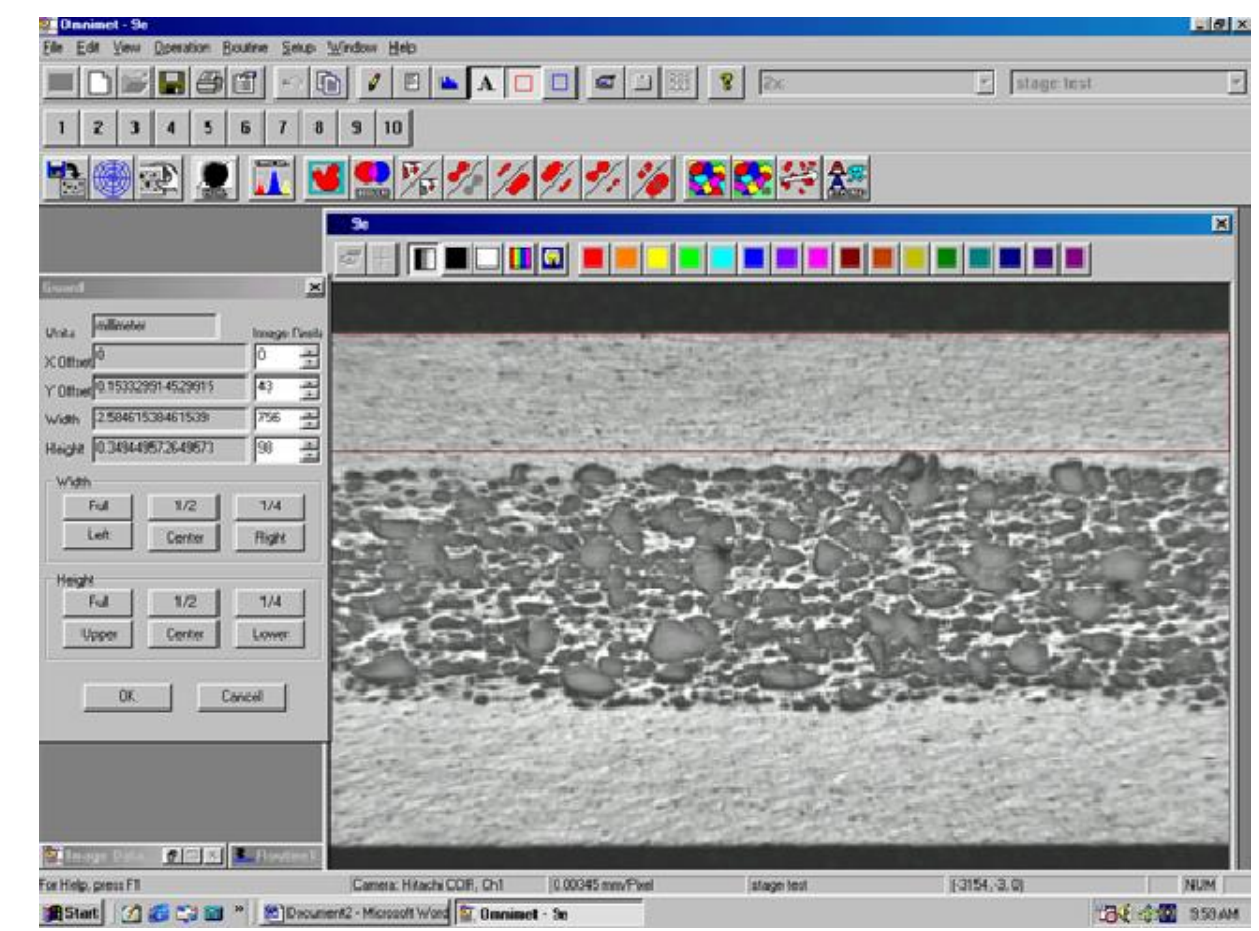

Figura 33 - Ilustração do procedimento atual, ou manual, para determinação das espessuras dos revestimentos e do núcleo da placa combustível.

Cada amostra de placa terá sua espessura integralmente visualizada e medida. A amostra é então movimentada, via Joystick, para que uma nova porção de seu comprimento se torne visível na tela. A cada movimentação adequada do Joystick, que não deixará qualquer trecho da amostra sem visualização para análise, uma nova medição de núcleo e de revestimentos será realizada.

Este procedimento atual de medição de espessuras de núcleos e revestimentos de placas combustíveis, desde a preparação das amostras até a varredura completa das imagens obtidas pela técnica descrita, tem duração de 288 horas. A Figura 34 (que segue) ilustra, como exemplo, a folha de resultados obtida para a placa combustível USi-691, na qual estão contidos os resultados obtidos a partir da atual metodologia. Os valores apresentados se referem às regiões centrais $(5,7$ e 9$)$ e terminais $(1,3,11$ e 13) constantes na especificação, cujo número de referência é R19-IPN-213 PR-2DJ-003.

A norma de produção técnica de medidas segue a especificação PSI.REN.IEAR1.002-ESPT.004 e desenho R19-IPN-213PR-2DJ-003/R:05 (os valores serão mostrados no próximo tópico deste trabalho). 


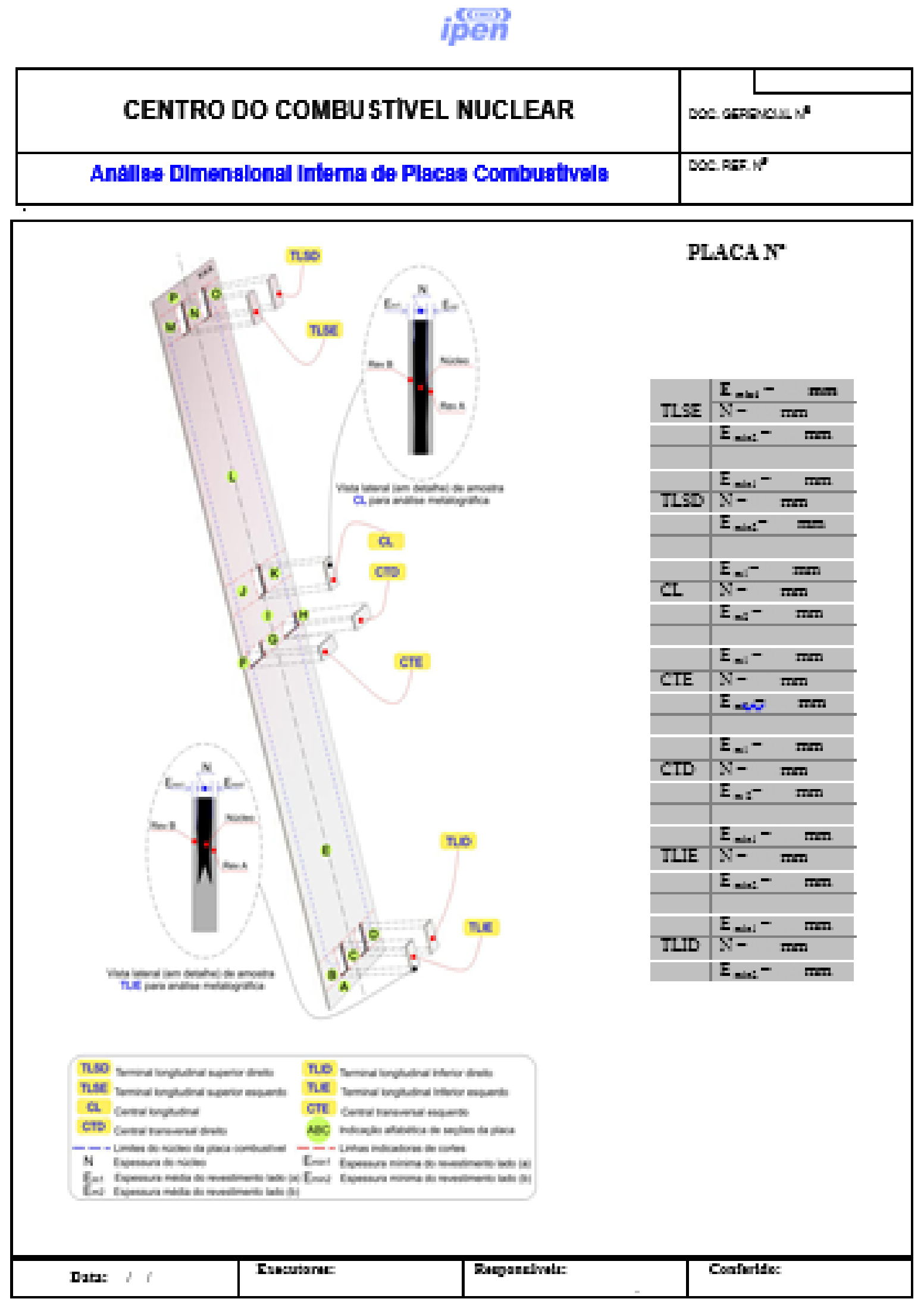

Figura 34 - Documento de qualificação do combustível. 
São verificadas as medidas de valores mínimos de espessura de revestimento das amostras situadas nas quatro regiões terminais da placa (1TLIE; 3-TLID; 11-TLSE e 13-TLSD), enquanto que para as três amostras situadas em suas regiões centrais (5-CTE; 7-CTD e 9-CL) são efetuadas medidas de valores médios de revestimento e de núcleo. 


\section{RESULTADOS E DISCUSSÕES}

Para desenvolver o novo método de medição das espessuras de núcleos e revestimentos de placas combustíveis, foi utilizado o software Omnimet Enterprise. Quanto ao processo de medição proposto, trata-se da criação de um programa computacional, a partir de tal software, com uma série de passos - que recebem o nome de Rotina. Sua função é, então, descrever o passo a passo do que será feito na imagem inicial, o que equivale a dizer que a execução de cada etapa da Rotina criada é capaz de, gradualmente, diferenciar os elementos constituintes da amostra. Para tanto, podem ser distinguidos através da atribuição de cores, dilatações e contorno de grãos.

A Rotina elaborada deve ser executada completamente, o que resulta na diferenciação dos materiais constituintes do núcleo $\left(\mathrm{U}_{3} \mathrm{Si}_{2}\right.$ disperso em $\left.\mathrm{Al}\right) \mathrm{e}$ do revestimento (Al); com isso, podem ser medidos automaticamente pelo programa, gerando, ao seu final, valores numéricos estatísticos para as espessuras do revestimento e do núcleo. Tais dados, gerados a partir desta Rotina desenvolvida, serão comparados com os dados obtidos a partir da medição atual das espessuras de núcleos e revestimentos.

O novo método desenvolvido pode ser aplicado automaticamente (bastando apenas realizar uma varredura da amostra para captação de imagens), o que implica em grande economia de tempo quando comparado ao método atual de medição. Para que seja qualificado, o método proposto será comparado com o método atual de medição das espessuras de núcleos e revestimentos.

\subsection{Quanto à obtenção das imagens para aplicação das Rotinas}

A partir dos experimentos realizados, notou-se que as imagens coletadas através da técnica de Microscopia Eletrônica de Varredura (MEV) para elétrons retroespalhados apresentavam melhor desempenho para a obtenção dos resultados, após a aplicação da Rotina, do que aquelas capturadas pelo microscópio óptico. 
Abaixo (Figura 35), encontra-se uma imagem capturada através do microscópio óptico e, em seguida, outra (Figura 36), obtida através da técnica de Microscopia Eletrônica de Varredura para elétrons retroespalhados.

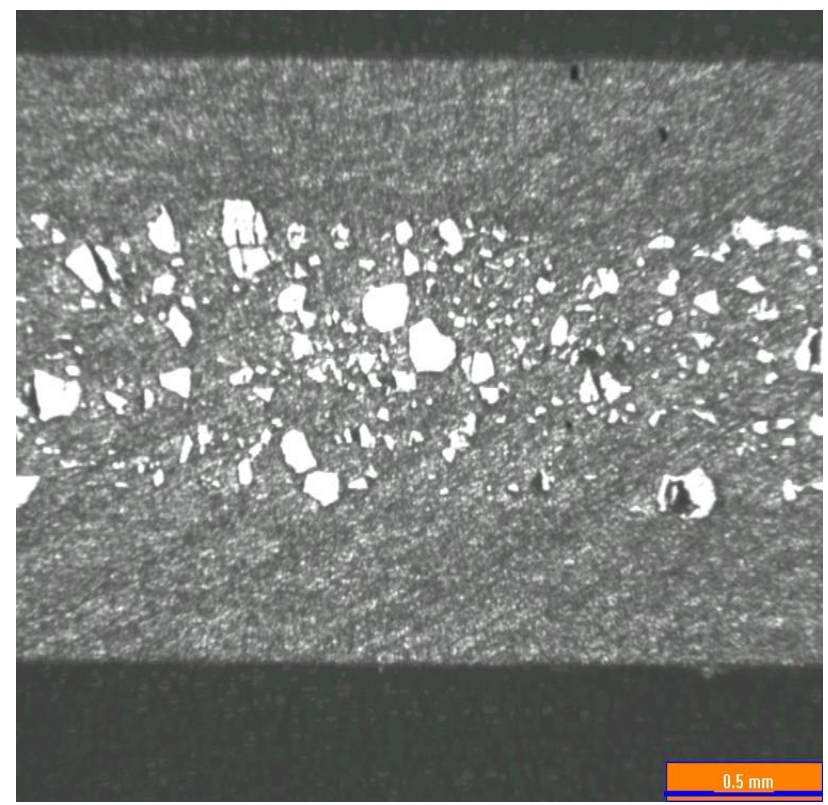

Figura 35 - Imagem obtida através do microscópio óptico.

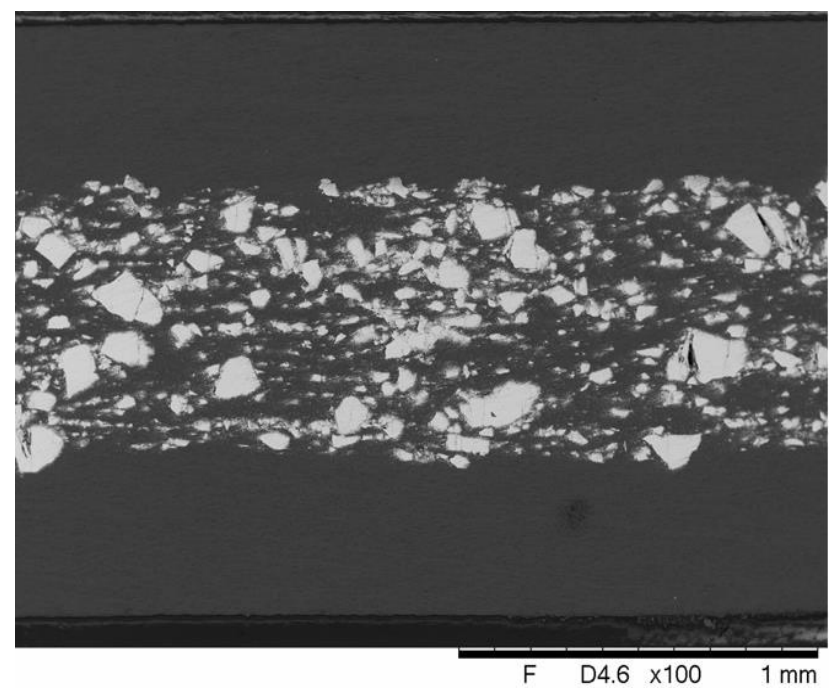

Figura 36 -Imagem obtida por Microscopia Eletrônica de Varredura, para elétrons retro espalhados.

Como é possível perceber, a Figura 35 apresenta maior quantidade de manchas, ou aberrações, em sua constituição, tornando-se difícil a diferenciação das fases e contornos de grãos com a aplicação da Rotina. Já a Figura 36, obtida através de MEV para elétrons retro espalhados, mostrou 
melhor qualidade já que não há as mesmas aberrações apresentadas pela técnica de Microscopia Óptica. Subsequentemente, a Rotina aplicada fará uma diferenciação mais segura das fases e dos contornos de grãos de $\mathrm{U}_{3} \mathrm{Si}_{2}$ e da matriz de alumínio.

Em decorrência disso, neste trabalho, a Rotina será aplicada nas imagens coletadas por MEV para elétrons retroespalhados.

\subsection{Quanto ao desenvolvimento do método de medição, ou criação das Rotinas}

A Figura 37 mostra três regiões de uma placa combustível, a qual irá compor o elemento combustível. A região A representa a parte não-periférica da placa combustível, enquanto as regiões $B$ e $C$ são periféricas.

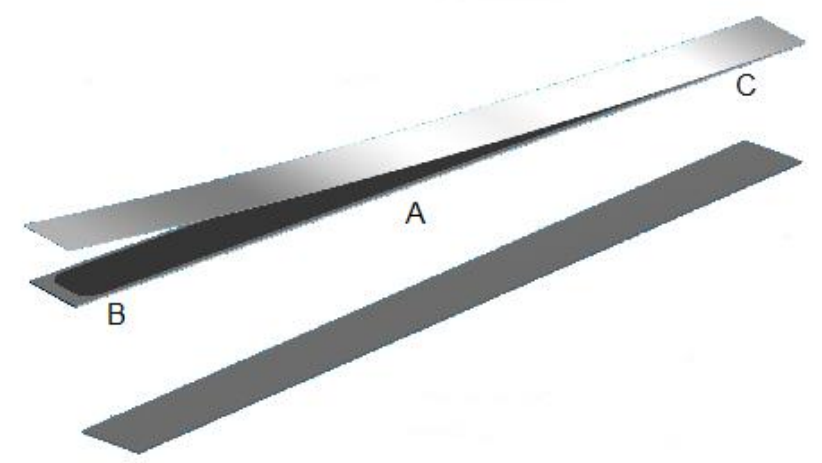

Figura 37 - Regiões da placa combustível.

A imagem capturada é recebida pelo programa utilizado. Como já foi dito, a qualidade das imagens se apresenta melhor para análise (sem tantos ruídos, ou aberrações) quando obtida por meio de Microscopia Eletrônica de Varredura (para elétrons retroespalhados). A Figura 38, a seguir, possui três imagens capturadas por MEV (ou três frames), que representam as regiões A, B e C da Figura 37 (acima). 


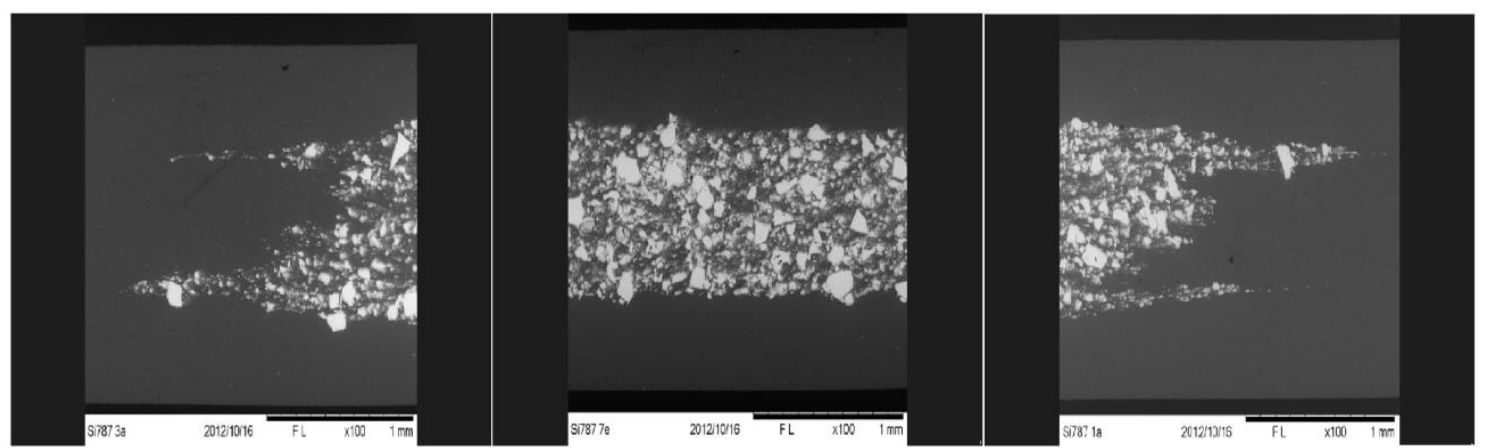

Figura 38 - Regiões A, B e C, capturadas por MEV (elétrons retroespalhados).

O software utilizado é capaz de trabalhar as imagens de forma automática devido à aplicação das Rotinas, fornecendo as informações especificadas para a placa combustível.

Neste trabalho, foram criadas duas Rotinas diferentes para a medição das espessuras de núcleos e revestimentos das placas, das quais uma se aplica às regiões terminais da placa (aqui denominada Rotina 1), enquanto a outra realiza medições para regiões não terminais (ou centrais) da mesma (Rotina 2).

Abaixo, tem-se a Rotina 1 (Figura 39), criada a partir das ferramentas contidas no software Omnimet Enterprise. Em seguida, também é apresentada a Rotina 2 (Figura 40), que se diferencia ligeiramente da primeira pois se diferem as imagens coletadas, como mostrado na Figura 38 (regiões terminais e centrais). 


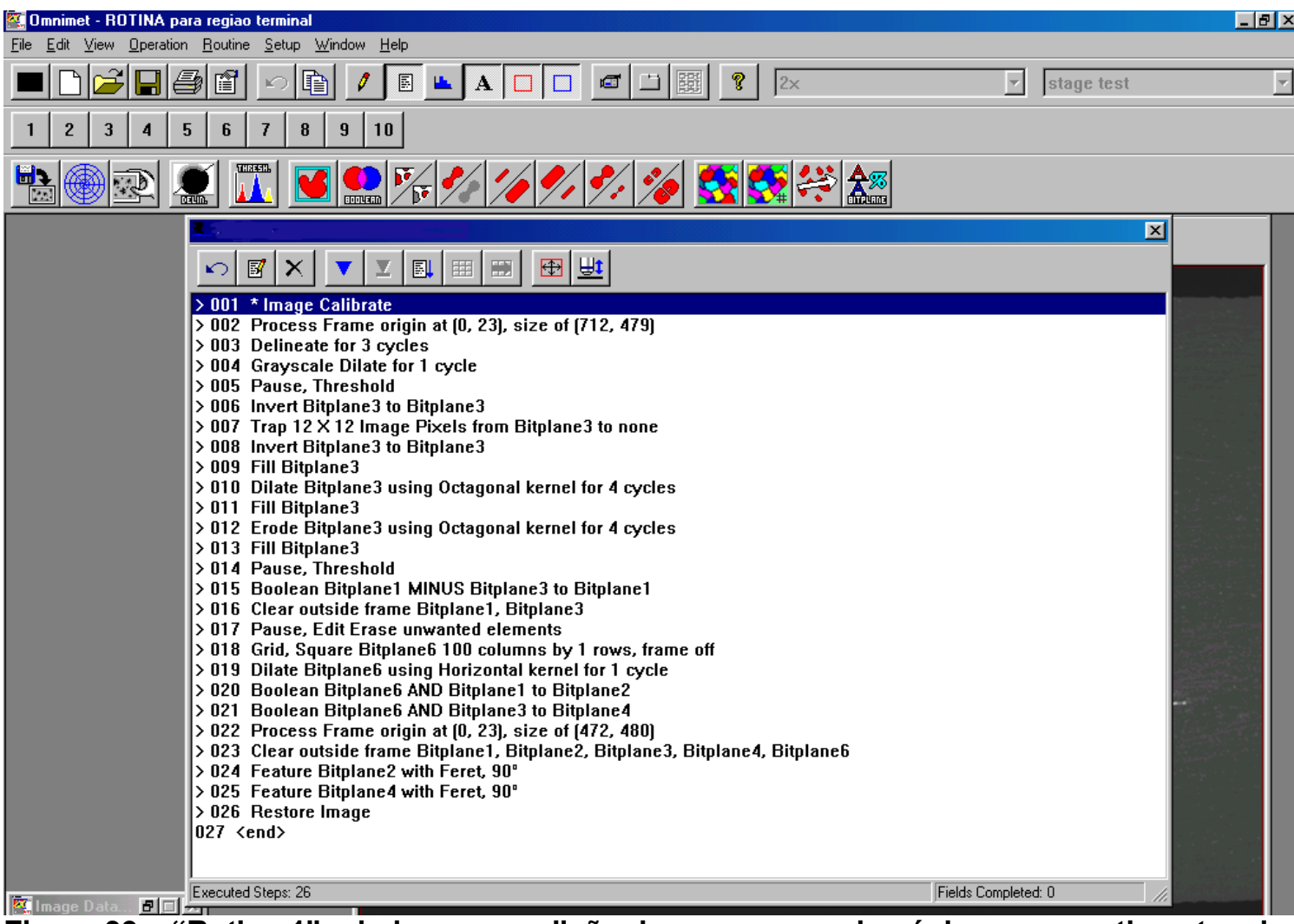

Figura 39 - "Rotina 1" criada para medição de espessuras de núcleos e revestimentos de placas combustíveis, para regiões terminais.

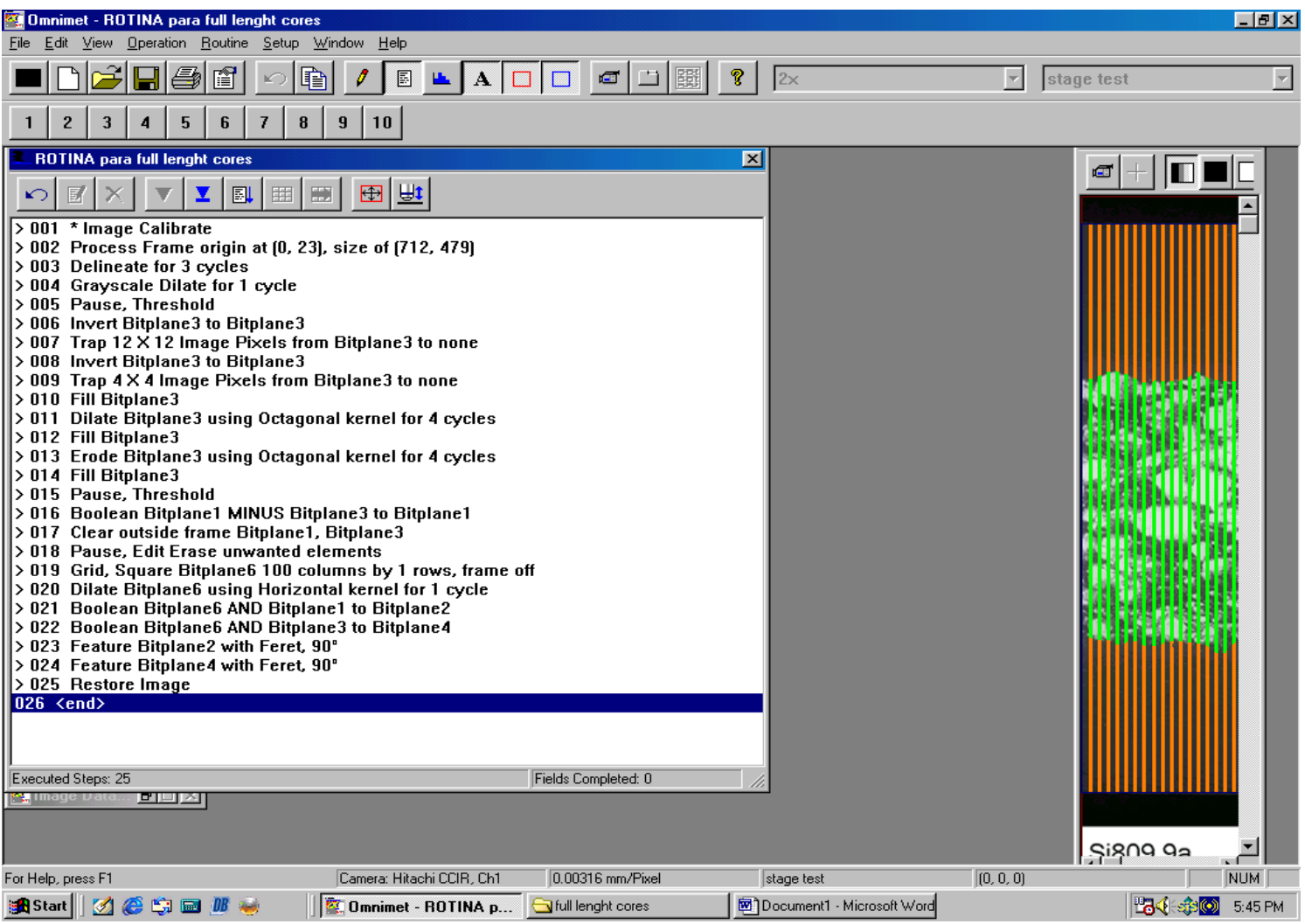

\section{Figura 40 - "Rotina 2" criada para medição de espessuras de núcleos e revestimentos de} placas combustíveis, para regiões centrais. 


\subsection{Quanto à aplicação do procedimento atual para comparação}

Para que o novo método proposto fosse qualificado (ou validado) para a medição de núcleos e espessuras de placas de elementos combustíveis, foram feitos estudos através de três placas combustíveis denominadas Si809, Si833 e Si852, desenvolvidas pelo Centro de Combustível Nuclear (CCN - IPEN).

A partir destas três placas foram preparadas as amostras, como já foi descrito. Em seguida, estas amostras foram submetidas à MEV (para elétrons retroespalhados) e, então, delas foram coletadas diversas imagens, as quais foram enviadas ao programa Omnimet Enterprise.

Primeiramente, foram realizadas as análises de tais imagens a partir do atual processo de medição de espessuras do núcleo e revestimentos. Para isso, preencheu-se manualmente as tabelas abaixo: Tabela 1, para a placa Si809; Tabela 2, para a placa Si833; Tabela 3, para a placa Si852. Em cada uma das tabelas apresentadas abaixo, estão contidas as sete regiões consideradas das placas combustíveis (TLIE, TLID, CTE, CTD, CL, TSLE, TSLD).

Tabela 1 - Tabela de preenchimento manual, a partir o atual método de medição, para a placa Si809.

\begin{tabular}{|c|c|c|c|c|c|}
\hline \multicolumn{6}{|c|}{ PLACA Si809 } \\
\hline \multirow{3}{*}{\multicolumn{2}{|c|}{ IDENTIFICAÇÃO }} & \multicolumn{3}{|c|}{ REVESTIMENTO } & NÚCLEO \\
\hline & & \multirow{2}{*}{ ESPECIFICADO } & \multicolumn{2}{|c|}{ MEDIDO } & \multirow{2}{*}{ ESPECIFICADO } \\
\hline & & & $\mathrm{R} 1$ & $\mathrm{R} 2$ & \\
\hline \multirow{6}{*}{ TLIE } & \multirow{6}{*}{001} & \multirow{6}{*}{$0,25-0,46$} & 0,33 & 0,40 & \multirow{6}{*}{$0,71-0,97$} \\
\hline & & & 0,31 & 0,30 & \\
\hline & & & 0,29 & 0,33 & \\
\hline & & & 0,31 & 0,37 & \\
\hline & & & 0,35 & 0,34 & \\
\hline & & & 0,29 & 0,35 & \\
\hline & & & & & \\
\hline \multirow{5}{*}{ TLID } & \multirow{5}{*}{003} & \multirow{5}{*}{$0,25-0,46$} & 0,35 & 0,35 & \multirow{5}{*}{$0,71-0,97$} \\
\hline & & & 0,32 & 0,29 & \\
\hline & & & 0,33 & 0,34 & \\
\hline & & & 0,32 & 0,34 & \\
\hline & & & 0,32 & 0,34 & \\
\hline
\end{tabular}




\begin{tabular}{|c|c|c|c|c|c|}
\hline & & & 0,32 & 0,29 & \\
\hline \multirow{8}{*}{ CTE } & \multirow{8}{*}{005} & \multirow{8}{*}{$0,33-0,46$} & 0,36 & 0,39 & \multirow{8}{*}{$0,71-0,81$} \\
\hline & & & 0,36 & 0,36 & \\
\hline & & & 0,35 & 0,32 & \\
\hline & & & 0,34 & 0,35 & \\
\hline & & & 0,36 & 0,37 & \\
\hline & & & 0,31 & 0,38 & \\
\hline & & & 0,37 & 0,38 & \\
\hline & & & 0,35 & 0,36 & \\
\hline \multirow{7}{*}{ CTD } & \multirow{7}{*}{007} & \multirow{7}{*}{$0,33-0,46$} & 0,37 & 0,40 & \multirow{7}{*}{$0,71-0,81$} \\
\hline & & & 0,37 & 0,39 & \\
\hline & & & 0,35 & 0,39 & \\
\hline & & & 0,35 & 0,35 & \\
\hline & & & 0,35 & 0,37 & \\
\hline & & & 0,36 & 0,31 & \\
\hline & & & 0,358 & 0,368 & \\
\hline
\end{tabular}

\begin{tabular}{|c|c|c|c|c|c|}
\hline \multirow{9}{*}{$\mathrm{CL}$} & \multirow{9}{*}{009} & \multirow{9}{*}{$0,33-0,46$} & 0,36 & 0,39 & \multirow{9}{*}{$0,71-0,81$} \\
\hline & & & 0,37 & 0,37 & \\
\hline & & & 0,36 & 0,40 & \\
\hline & & & 0,40 & 0,42 & \\
\hline & & & 0,36 & 0,38 & \\
\hline & & & 0,36 & 0,37 & \\
\hline & & & 0,44 & 0,36 & \\
\hline & & & 0,36 & 0,39 & \\
\hline & & & 0,38 & 0,385 & \\
\hline
\end{tabular}

\begin{tabular}{|c|c|c|c|c|c|}
\hline \multirow{7}{*}{ TSLE } & \multirow{7}{*}{011} & \multirow{7}{*}{$0,25-0,46$} & 0,32 & 0,31 & \multirow{7}{*}{$0,71-0,97$} \\
\hline & & & 0,33 & 0,34 & \\
\hline & & & 0,30 & 0,35 & \\
\hline & & & 0,34 & 0,40 & \\
\hline & & & 0,36 & 0,36 & \\
\hline & & & 0,35 & 0,38 & \\
\hline & & & 0,30 & 0,31 & \\
\hline \multirow{2}{*}{ TSLD } & \multirow{2}{*}{013} & \multirow{2}{*}{$0,25-0,46$} & 0,35 & 0,32 & \multirow{2}{*}{$0,71-0,97$} \\
\hline & & & 0,35 & 0,34 & \\
\hline
\end{tabular}




\begin{tabular}{|l|l|}
\hline 0,37 & 0,33 \\
\hline 0,35 & 0,33 \\
\hline 0,36 & 0,33 \\
\hline 0,35 & 0,32 \\
\hline
\end{tabular}

Tabela 2 - Tabela de preenchimento manual, a partir o atual método de medição, para a placa Si833.

\section{PLACA Si833}

\begin{tabular}{|c|c|c|c|c|c|}
\hline \multirow{3}{*}{\multicolumn{2}{|c|}{ IDENTIFICAÇÃO }} & \multicolumn{3}{|c|}{ REVESTIMENTO } & \multirow{3}{*}{$\begin{array}{c}\text { NÚCLEO } \\
\text { ESPECIFICADO }\end{array}$} \\
\hline & & \multirow{2}{*}{ ESPECIFICADO } & \multicolumn{2}{|c|}{ MEDIDO } & \\
\hline & & & $\mathrm{R} 1$ & R2 & \\
\hline \multirow{7}{*}{ TLIE } & \multirow{7}{*}{001} & \multirow{7}{*}{$0,25-0,46$} & 0,33 & 0,34 & \multirow{7}{*}{$0,71-0,97$} \\
\hline & & & 0,35 & 0,35 & \\
\hline & & & 0,33 & 0,34 & \\
\hline & & & 0,38 & 0,34 & \\
\hline & & & 0,38 & 0,34 & \\
\hline & & & 0,39 & 0,38 & \\
\hline & & & 0,33 & 0,34 & \\
\hline
\end{tabular}

\begin{tabular}{|c|c|c|c|c|c|}
\hline \multirow{7}{*}{ TLID } & \multirow{7}{*}{003} & \multirow{7}{*}{$0,25-0,46$} & 0,35 & 0,36 & \multirow{7}{*}{$0,71-0,97$} \\
\hline & & & 0,35 & 0,34 & \\
\hline & & & 0,34 & 0,35 & \\
\hline & & & 0,36 & 0,34 & \\
\hline & & & 0,37 & 0,37 & \\
\hline & & & 0,39 & 0,38 & \\
\hline & & & 0,34 & 0,34 & \\
\hline
\end{tabular}

\begin{tabular}{|c|c|c|c|c|c|}
\hline \multirow{8}{*}{ CTE } & \multirow{8}{*}{005} & \multirow{8}{*}{$0,33-0,46$} & 0,39 & 0,39 & \multirow{8}{*}{$0,71-0,81$} \\
\hline & & & 0,38 & 0,36 & \\
\hline & & & 0,41 & 0,40 & \\
\hline & & & 0,40 & 0,38 & \\
\hline & & & 0,39 & 0,33 & \\
\hline & & & 0,40 & 0,40 & \\
\hline & & & 0,40 & 0,38 & \\
\hline & & & 0,40 & 0,38 & \\
\hline
\end{tabular}

\begin{tabular}{|c|c|c|c|c|c|}
\hline \multirow{8}{*}{ CTD } & \multirow{8}{*}{007} & \multirow{8}{*}{$0,33-0,46$} & 0,39 & 0,40 & \multirow{8}{*}{$0,71-0,81$} \\
\hline & & & 0,38 & 0,39 & \\
\hline & & & 0,38 & 0,38 & \\
\hline & & & 0,38 & 0,36 & \\
\hline & & & 0,38 & 0,37 & \\
\hline & & & 0,4 & 0,36 & \\
\hline & & & 0,40 & 0,38 & \\
\hline & & & 0,39 & 0,38 & \\
\hline \multirow{2}{*}{$C L$} & \multirow{2}{*}{009} & \multirow{2}{*}{$0,33-0,46$} & 0,41 & 0,40 & \multirow{2}{*}{$0,71-0,81$} \\
\hline & & & 0,42 & 0,36 & \\
\hline
\end{tabular}




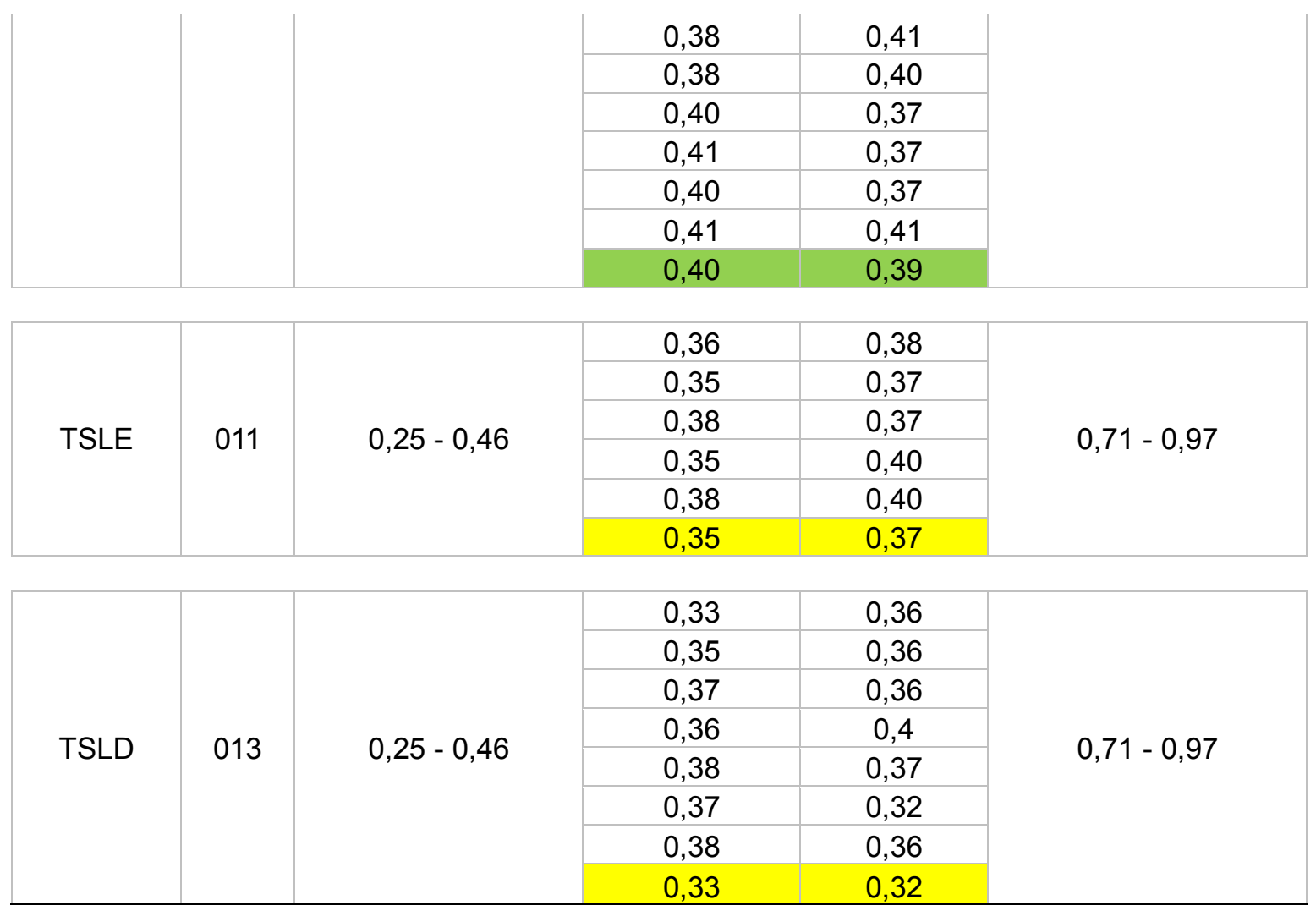

Tabela 3 - Tabela de preenchimento manual, a partir o atual método de medição, para a placa Si852.

\begin{tabular}{|c|c|c|c|c|c|}
\hline PLACA & & & & & \\
\hline & & & MEN 1 & & NÚCLEO \\
\hline IDENTIF & ÇÃO & & & & \\
\hline & & ESPECIFICADO & $\mathrm{R} 1$ & $\mathrm{R} 2$ & ESPECIFICADO \\
\hline & & & 0,33 & 0,31 & \\
\hline & & & 0,34 & 0,30 & \\
\hline & & & 0,34 & 0,34 & \\
\hline TLIE & 001 & $0,25-0,46$ & 0,34 & 0,34 & $0,71-0,97$ \\
\hline & & & 0,34 & 0,34 & \\
\hline & & & 0,34 & 0,34 & \\
\hline & & & 0,34 & 0,33 & \\
\hline & & & 0.32 & 0.33 & \\
\hline & & & 0,37 & 0,34 & \\
\hline & & & 0,39 & 0,34 & \\
\hline TLID & 003 & $0,25-0,46$ & 0,38 & 0,35 & $0,71-0,97$ \\
\hline & & & 0,39 & 0,33 & \\
\hline & & & 0,41 & 0,37 & \\
\hline & & & 0,32 & 0,33 & \\
\hline & & & 0,35 & 0,36 & \\
\hline CTE & 005 & $0,33-0,46$ & 0,35 & 0,37 & $0,71-0,81$ \\
\hline
\end{tabular}




\begin{tabular}{|c|c|c|c|c|c|}
\hline & & & 0,39 & 0,40 & \\
\hline & & & 0,36 & 0,33 & \\
\hline & & & 0,38 & 0,39 & \\
\hline & & & 0,39 & 0,38 & \\
\hline & & & 0,36 & 0,39 & \\
\hline & & & 0,37 & 0,37 & \\
\hline \multirow{11}{*}{ CTD } & \multirow{11}{*}{007} & \multirow{11}{*}{$0,33-0,46$} & & & \multirow{11}{*}{$0,71-0,81$} \\
\hline & & & 0,38 & 0,40 & \\
\hline & & & 0,40 & 0,41 & \\
\hline & & & 0,40 & 0,41 & \\
\hline & & & 0,38 & 0,39 & \\
\hline & & & 0,38 & 0,38 & \\
\hline & & & 0,36 & 0,41 & \\
\hline & & & 0,38 & 0,37 & \\
\hline & & & 0,39 & 0,38 & \\
\hline & & & 0,41 & 0,38 & \\
\hline & & & 0,39 & 0,39 & \\
\hline \multirow{9}{*}{$C L$} & \multirow{9}{*}{009} & \multirow{9}{*}{$0,33-0,46$} & 0,39 & 0,38 & \multirow{9}{*}{$0,71-0,81$} \\
\hline & & & 0,40 & 0,40 & \\
\hline & & & 0,40 & 0,38 & \\
\hline & & & 0,39 & 0,38 & \\
\hline & & & 0,34 & 0,38 & \\
\hline & & & 0,37 & 0,38 & \\
\hline & & & 0,37 & 0,39 & \\
\hline & & & 0,39 & 0,38 & \\
\hline & & & 0,38 & 0,38 & \\
\hline \multirow{7}{*}{ TSLE } & \multirow{7}{*}{011} & \multirow{7}{*}{$0,25-0,46$} & 0,32 & 0,35 & \multirow{7}{*}{$0,71-0,97$} \\
\hline & & & 0,33 & 0,32 & \\
\hline & & & 0,34 & 0,33 & \\
\hline & & & 0,31 & 0,36 & \\
\hline & & & 0,34 & 0,37 & \\
\hline & & & 0,34 & 0,36 & \\
\hline & & & 0,31 & 0,32 & \\
\hline \multirow{8}{*}{ TSLD } & \multirow{8}{*}{013} & \multirow{8}{*}{$0,25-0,46$} & 0,32 & 0,34 & \multirow{8}{*}{$0,71-0,97$} \\
\hline & & & 0,35 & 0,34 & \\
\hline & & & 0,37 & 0,35 & \\
\hline & & & 0,36 & 0,36 & \\
\hline & & & 0,37 & 0,34 & \\
\hline & & & 0,33 & 0,38 & \\
\hline & & & 0,38 & 0,37 & \\
\hline & & & 0,32 & 0,34 & \\
\hline
\end{tabular}

Nota-se que todas as medidas (coluna "MEDIDO") estão contidas dentro do intervalo de valores especificado por norma (coluna "ESPECIFICADO"), tanto para os revestimentos quanto para o núcleo. Isto demonstra a qualidade do método atual; todavia o tempo de realização é relativamente longo, de 288 horas (12 dias) para cada uma das placas. 


\subsection{Quanto à aplicação das Rotinas}

Depois de realizadas todas as medidas descritas acima, as imagens coletadas por MEV (para elétrons retroespalhados) foram testadas nos programas desenvolvidos, sendo submetidas às Rotinas 1 e 2. Os tópicos a seguir se referem à aplicação das Rotinas para cada uma das placas consideradas.

\subsubsection{Aplicação das Rotinas para a placa Si809}

No caso da primeira placa, Si809, escolheu-se, para a validação das Rotinas criadas, o frame correspondente à parte terminal da placa combustível, denominado 11 a (referente à parte TSLE), e um frame correspondente ao centro da placa, chamado de 9 a (referente à parte $C L$ ). Abaixo, seguem cinco imagens obtidas, representando cinco passos diferentes, os quais foram percorridos durante as aplicações das Rotinas - Figura 41 (Rotina 1) e Figura 42 (Rotina 2) -, bem como a escala das imagens. 

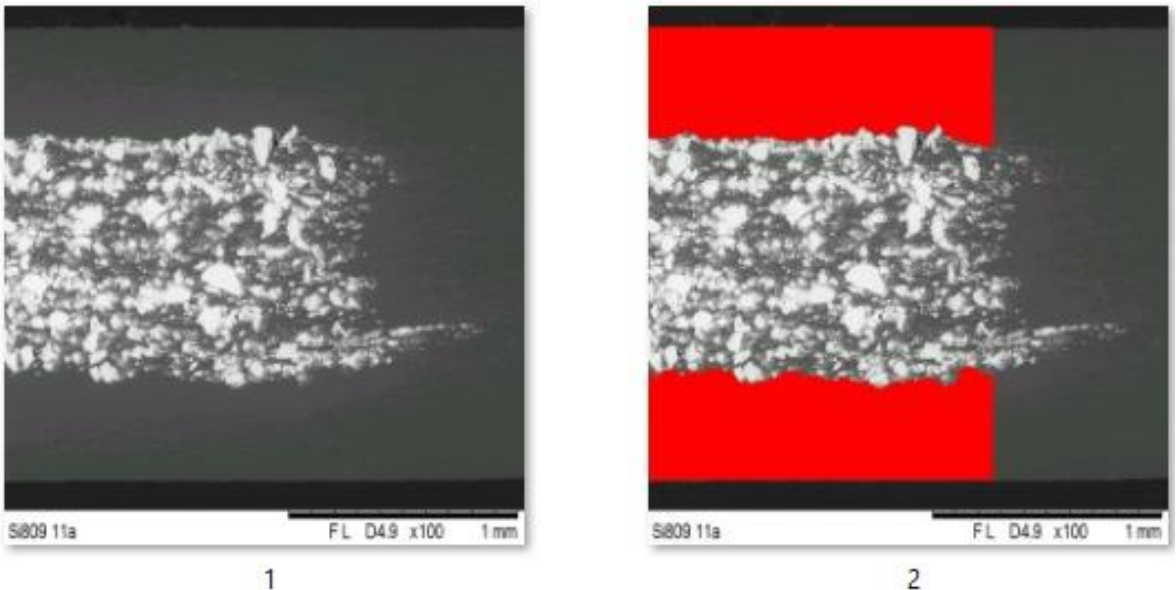

1
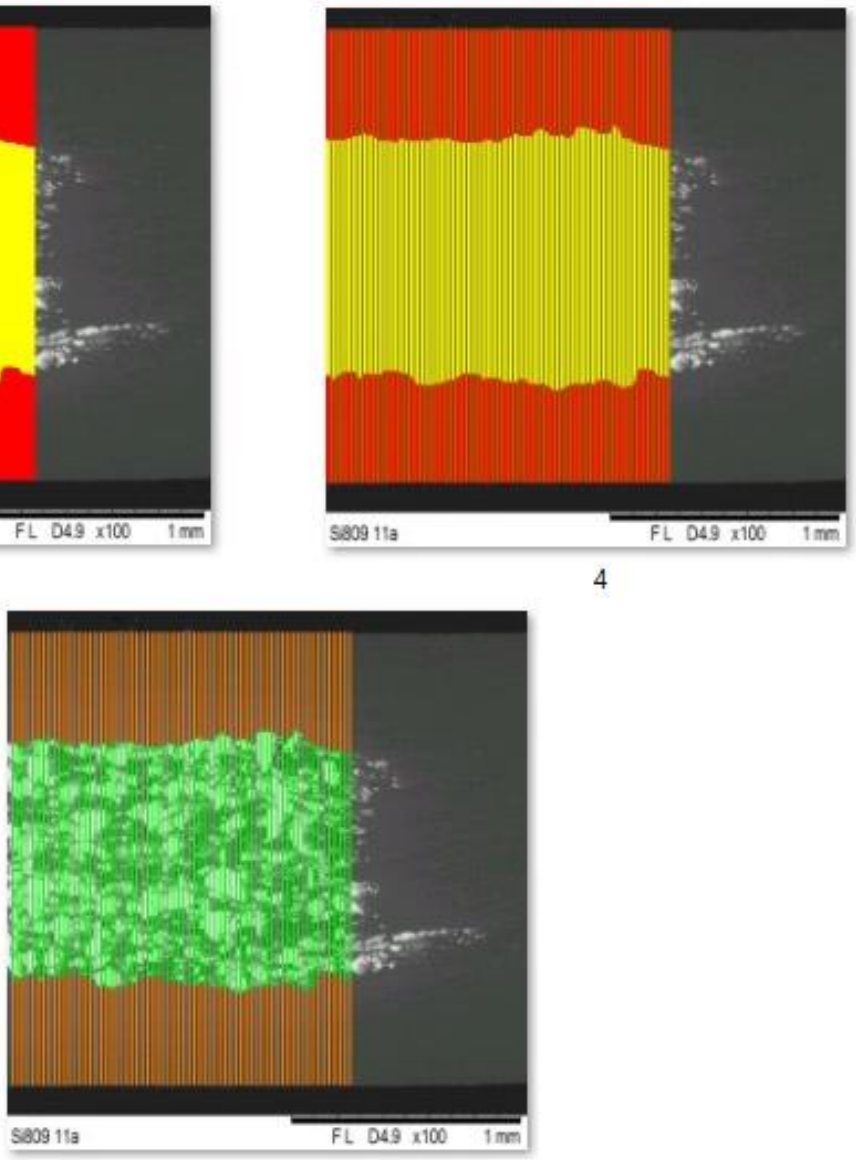

5

Figura 41 - Passos da aplicação da Rotina 1, para regiões terminais da placa Si809. 

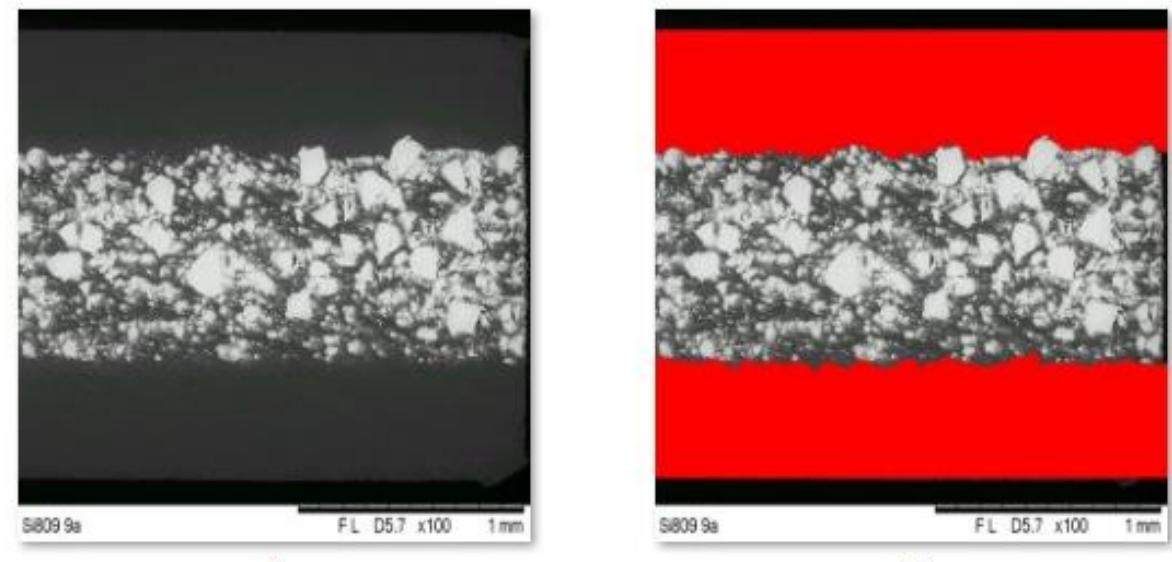

2
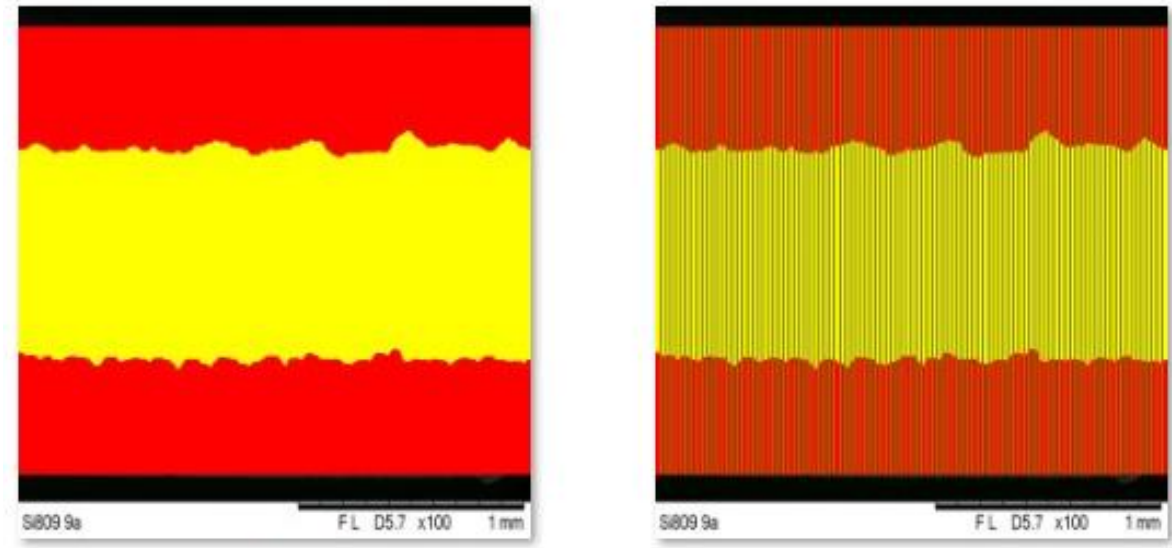

4

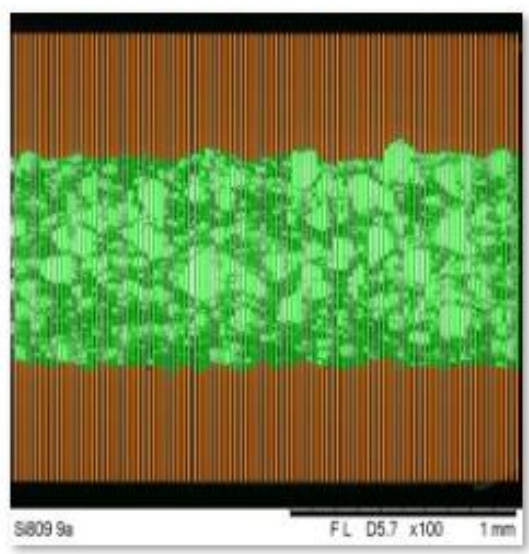

5

Figura 42 - Passos da aplicação da Rotina 2 para regiões não terminais da placa Si809.

Nas barras verticais do último passo representado nas Rotinas 1 e 2 (passo 5), podem ser percebidas duas cores diferentes: verde e laranja. As barras em verde se referem a medidas do núcleo, e as em laranja representam medições dos revestimentos. Em função desta escolha de cores, os resultados obtidos com as aplicações das Rotinas 1 e 2, apresentados nos histogramas, terão cores correspondentes. 
No caso da Rotina 1 (para regiões terminais), têm-se os resultados adiante. A Figura 43 mostra a imagem original, capturada pela técnica de MEV, enquanto a Figura 44 apresenta a imagem após a aplicação da referida Rotina.

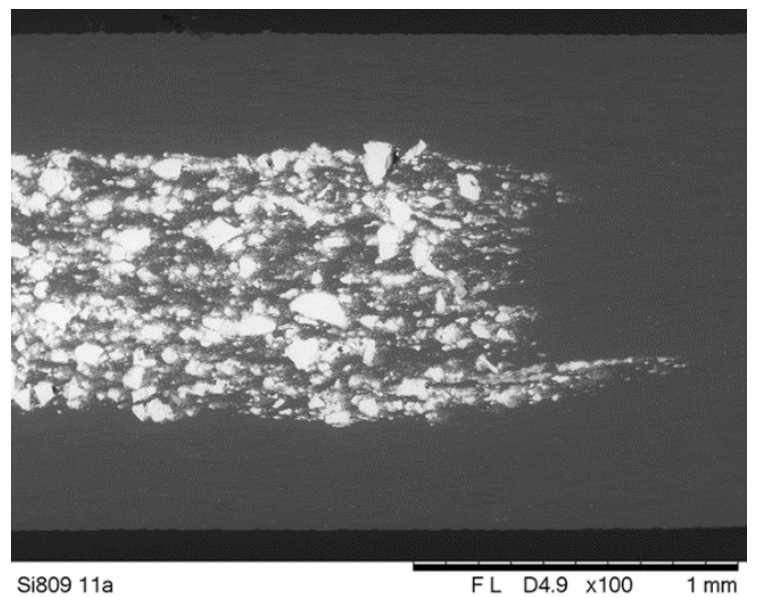

Figura 43 - Imagem original, capturada por MEV (para elétrons retroespalhados).

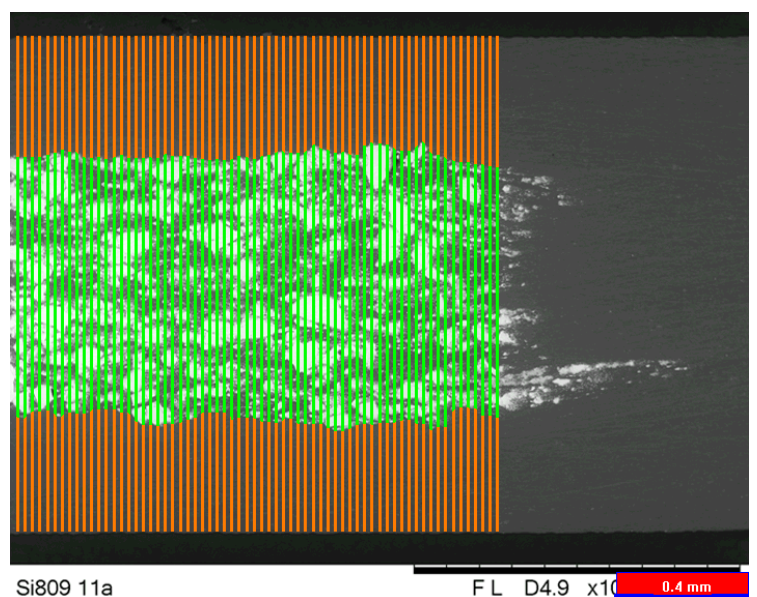

Figura 44 - Imagem após a aplicação da Rotina 1.

Como é possível perceber, o núcleo da placa combustível é representado pela cor verde, de modo que seu histograma correspondente, contendo a distribuição de suas espessuras (Figura 45), é dado pelo software como mostrado adiante. Tal histograma é obtido com o número de medidas do intervalo ("count") para cada intervalo de espessuras, em milímetros ( $\mathrm{mm})$, do núcleo da placa combustível. 


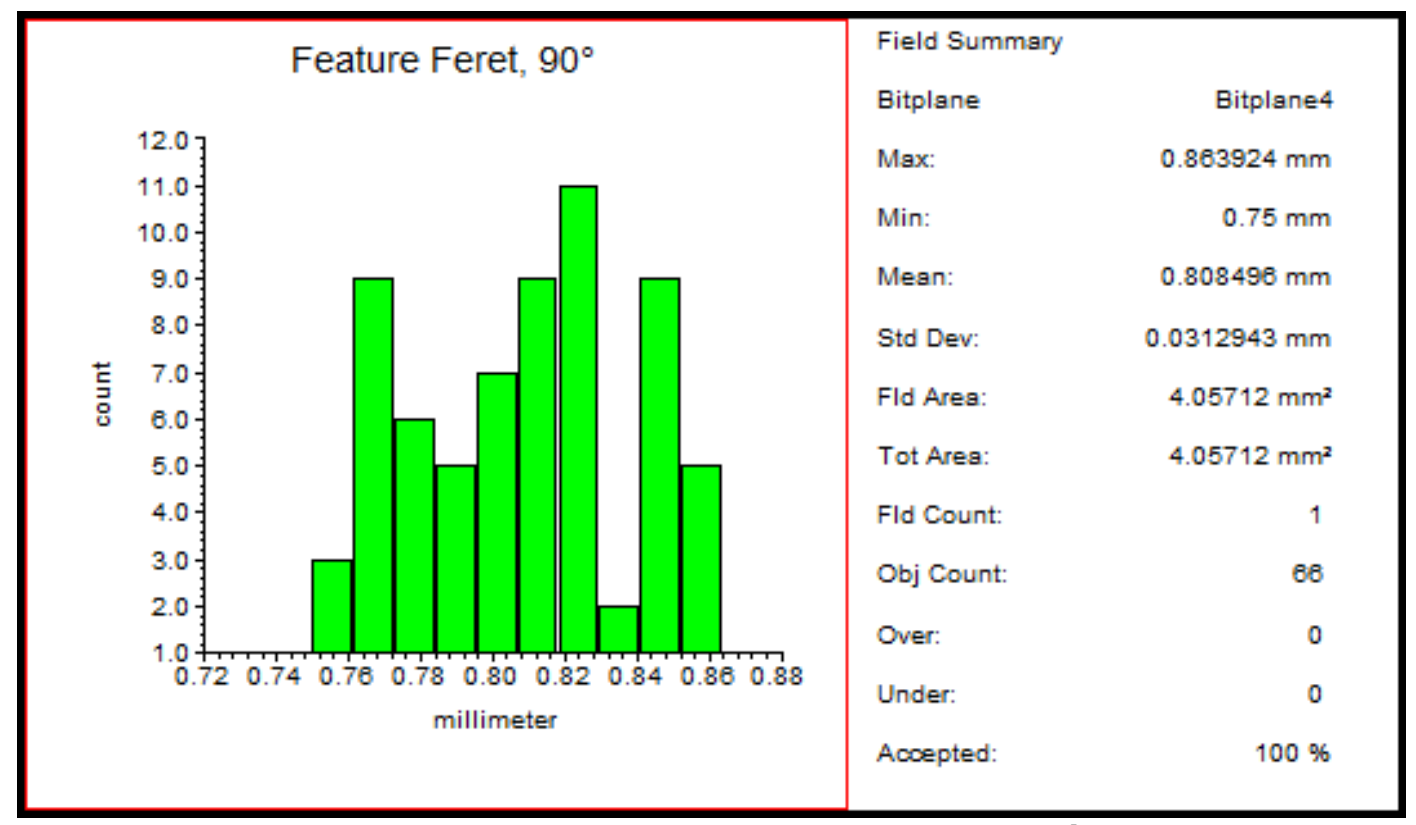

Figura 45 - Histograma com a distribuição das espessuras no núcleo da placa Si809.

Nota-se, observando o histograma acima, que os valores obtidos pelo software, a partir da aplicação da Rotina 1, estão, para o mínimo $(0,75 \mathrm{~mm})$ e o máximo $(0,863924 \mathrm{~mm})$, dentro do intervalo de valores especificado por norma $(0,71-0,97 \mathrm{~mm})$, como mostrou a Tabela 1 . Além disso, os valores obtidos pela aplicação do software concordam com os medidos manualmente - os quais apresentam-se no intervalo de 0,75 $\mathrm{mm}$ até $0,86 \mathrm{~mm}$.

Vale destacar que, através do método atual de medição, ou método manual, têm-se apenas 6 medidas, enquanto que através do novo método proposto (método automático criado pelas Rotinas) têm-se 66 medidas diferentes - apresentadas por suas distribuições no histograma acima.

Com relação aos revestimentos das partes terminais da placa Si809 - tanto o revestimento superior quanto o inferior -, estes são analisados pelas barras verticais de cor laranja; assim, o histograma gerado pelo software (Figura 46) é dado da maneira que se segue: 


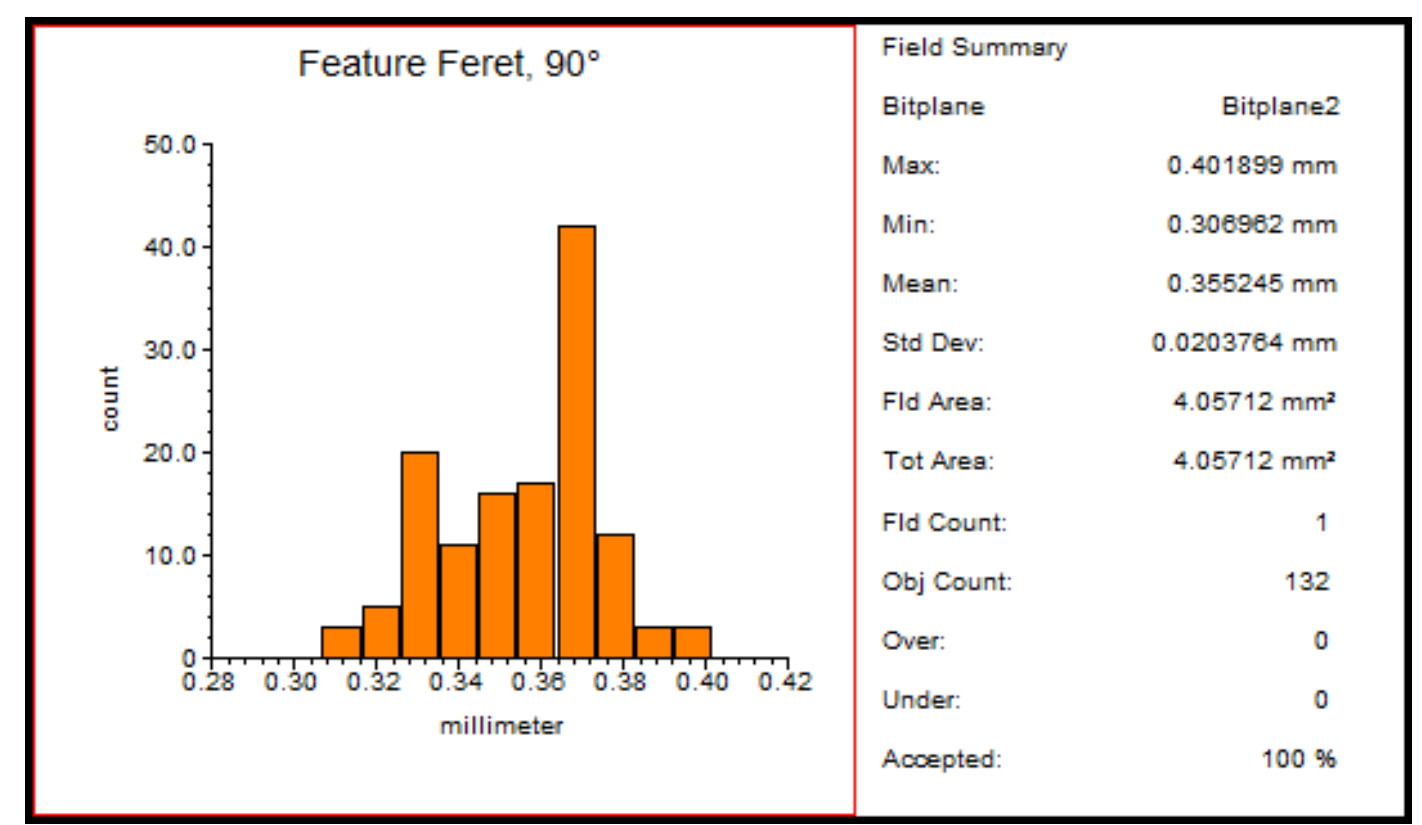

Figura 46 - Histograma com a distribuição das espessuras dos revestimentos da placa Si809.

Também neste caso, os valores encontrados pelo software estão, para o mínimo $(0,306962 \mathrm{~mm})$ e para o máximo $(0,401899 \mathrm{~mm})$, compreendidos no intervalo definido como norma $(0,25-0,46 \mathrm{~mm})$. Os valores obtidos automaticamente pela aplicação do software concordam com os valores medidos manualmente - que apresentam como mínimo $0,30 \mathrm{~mm}$ e máximo 0,40 $\mathrm{mm}$. Da mesma forma que antes, tem-se vantagem na a aplicação automática da Rotina, pois a partir dela são obtidas 132 medidas diferentes, enquanto que, manualmente, fazem-se apenas 12 (do mesmo frame).

No caso da Rotina 2, para regiões não terminais, ou contínuas, têmse os resultados abaixo. A Figura 47 traz a imagem original, capturada por Microscopia Eletrônica de Varredura; a Figura 48 mostra a imagem depois da aplicação da referida Rotina. 


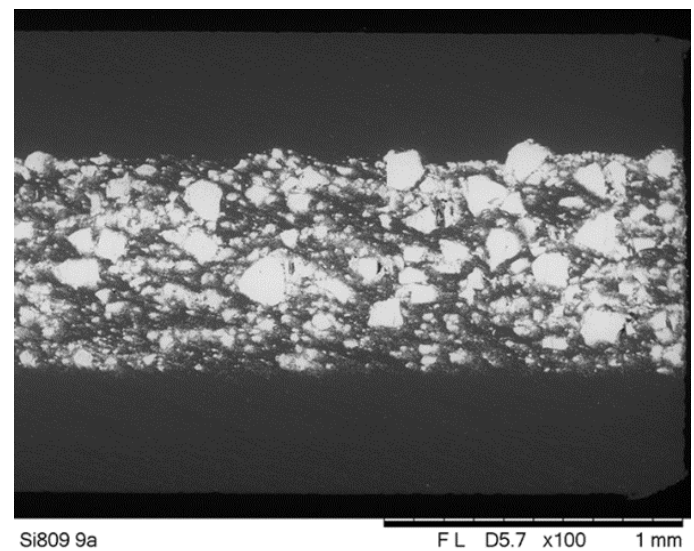

Figura 47 - Imagem original, capturada por MEV (elétrons retroespalhados).

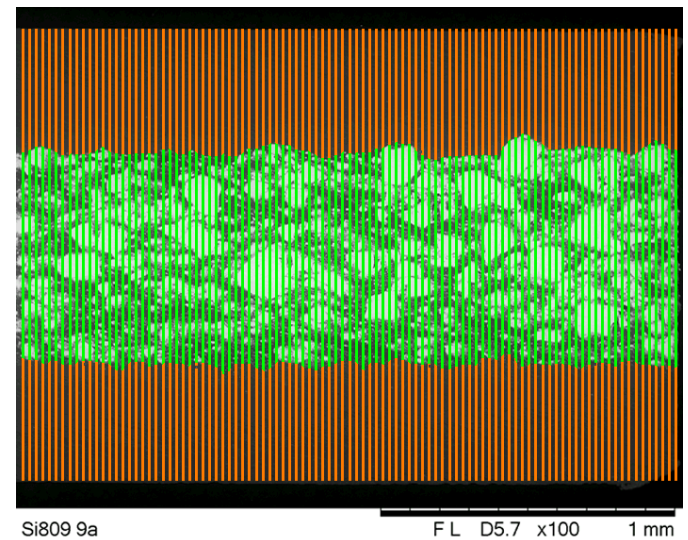

Figura 48 - Imagem após a aplicação da Rotina 2.

Novamente, o núcleo da placa combustível será representado pela cor verde, enquanto os revestimentos (inferior e superior, na figura) serão analisados com a cor laranja. A seguir, encontra-se o histograma para o núcleo (Figura 49) gerado com as medições feitas através do software, a partir da aplicação da Rotina 2, com as mesmas variáveis que os anteriores. 


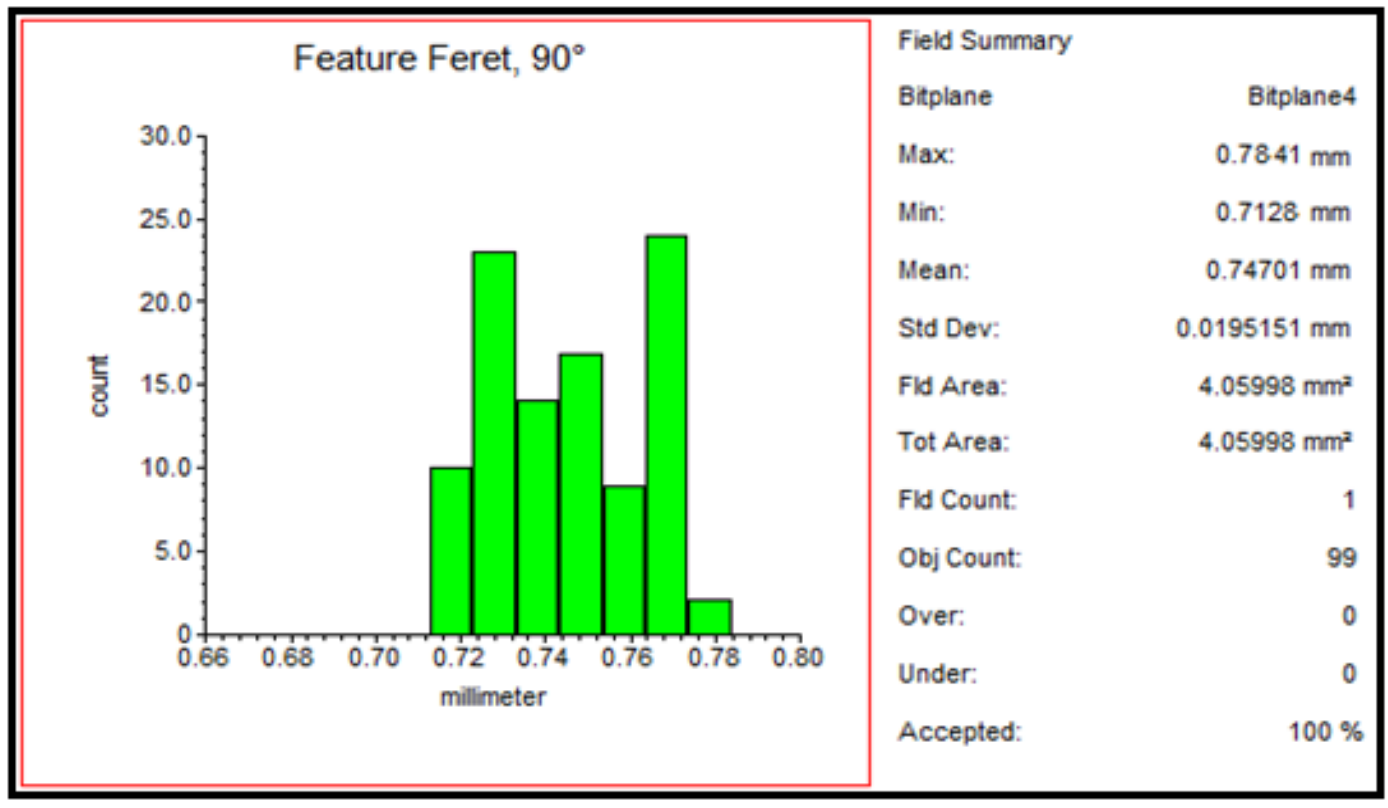

Figura 49 - Histograma com a distribuição das espessuras no núcleo da placa Si809.

No histograma acima (sobre distribuição de espessuras do núcleo da placa, onde está contido o material físsil), os valores obtidos pelo software (Rotina 2) estão, para o mínimo $(0,7128 \mathrm{~mm})$ e para o máximo $(0,7841 \mathrm{~mm})$, compreendidos no intervalo de valores especificado pelas normas de produção $(0,71-0,81 \mathrm{~mm})$, contido na Tabela 1 . No que diz respeito às medidas feitas manualmente (pelo atual processo de medições), os valores obtidos pela aplicação do software concordam com os mesmos - os quais se apresentam no intervalo de $0,71 \mathrm{~mm}$ até $0,78 \mathrm{~mm}$.

Com relação ao número de medições, têm-se apenas 8 medidas quando o frame é analisado manualmente, enquanto que pelo novo método proposto (método automático criado pelas Rotinas) têm-se 99 medidas diferentes - demonstrando grande vantagem do novo método criado. No que concerne aos revestimentos das partes terminais da placa Si809 - tanto o revestimento superior quanto o inferior - estes são analisados pelas barras verticais de cor laranja, de modo que o histograma gerado pelo software (Figura 50) é dado da seguinte maneira: 


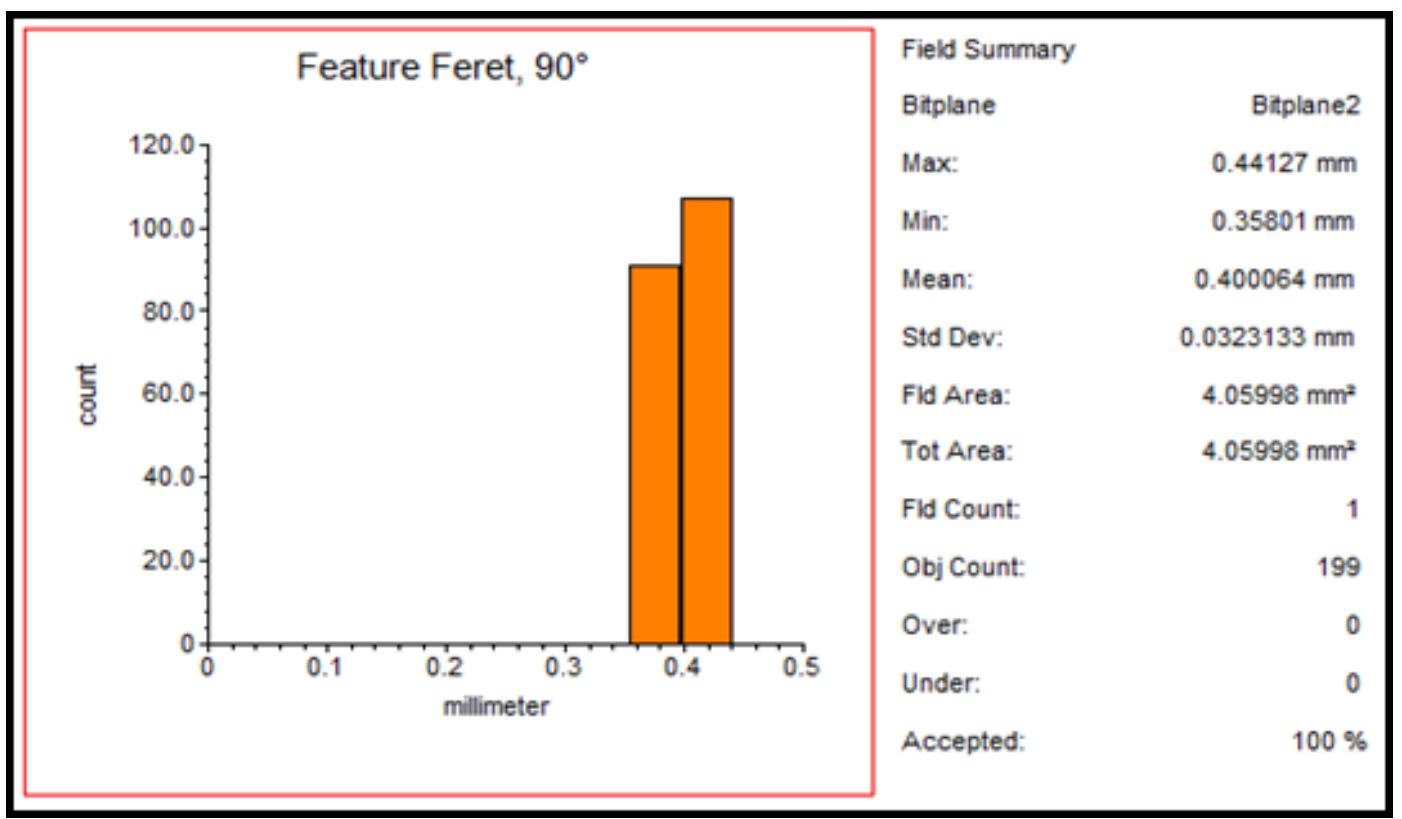

Figura 50 - Histograma referente aos revestimentos da placa Si809.

Constata-se, uma vez mais, que os valores encontrados pelo software estão, para o mínimo $(0,35801 \mathrm{~mm})$ e para o máximo $(0,44127 \mathrm{~mm})$, dentro no intervalo definido como norma $(0,33$ - 0,46 mm). Os valores obtidos automaticamente, pela aplicação do software, concordam com os medidos manualmente - que apresentam como mínimo 0,36 mm e máximo 0,44 $\mathrm{mm}$. Como antes, há vantagem na aplicação automática da Rotina, pois a partir dela obtêm-se 199 medidas diferentes, enquanto manualmente fazem-se, a partir do mesmo frame, apenas 16.

\subsubsection{Aplicação das Rotinas para a placa Si833}

Para a validação das Rotinas criadas, no caso da segunda placa, denominada Si833, foi escolhido o frame correspondente à parte terminal da placa combustível, denominado 11a (referente à parte TSLE), e um frame correspondente ao centro da placa, chamado de $9 a$ (referente à parte $C L$ ).

Para a Rotina 1 (para regiões terminais da placa), têm-se os resultados expostos abaixo. A Figura 51 mostra a imagem original, capturada pela técnica de MEV, enquanto a Figura 52 traz a imagem depois da aplicação da referida Rotina. 


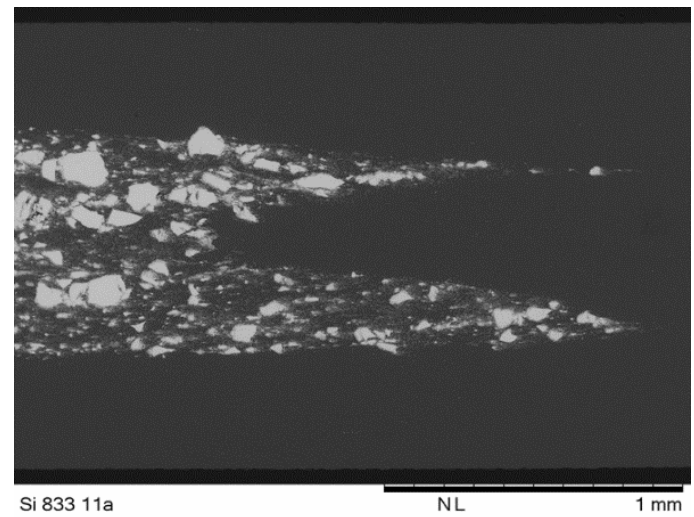

Figura 51 - Imagem original, capturada por MEV (elétrons retroespalhados).

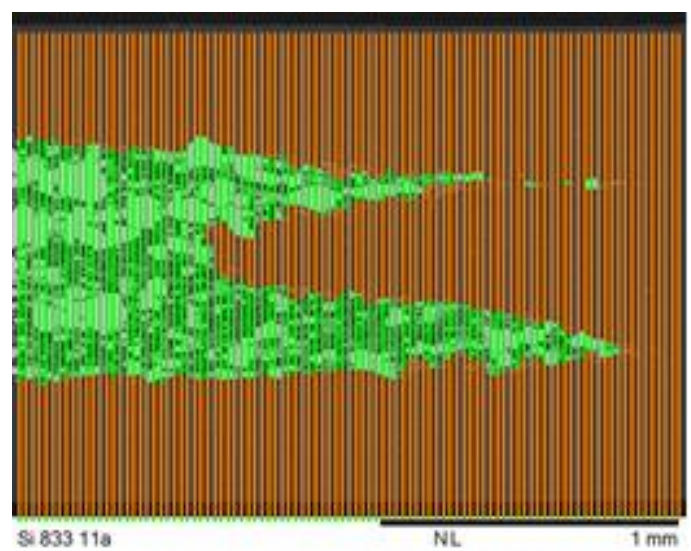

Figura 52 - Imagem após a aplicação da Rotina 1.

O núcleo da placa combustível é representado pela cor verde; o histograma correspondente, contendo a distribuição de suas espessuras (Figura 53), é gerado automaticamente pelo software como mostrado abaixo. Tal histograma é obtido calculando-se o número de vezes que determinadas espessuras (em mm) são medidas, por intervalo de tamanho, referentes ao núcleo da placa combustível. 


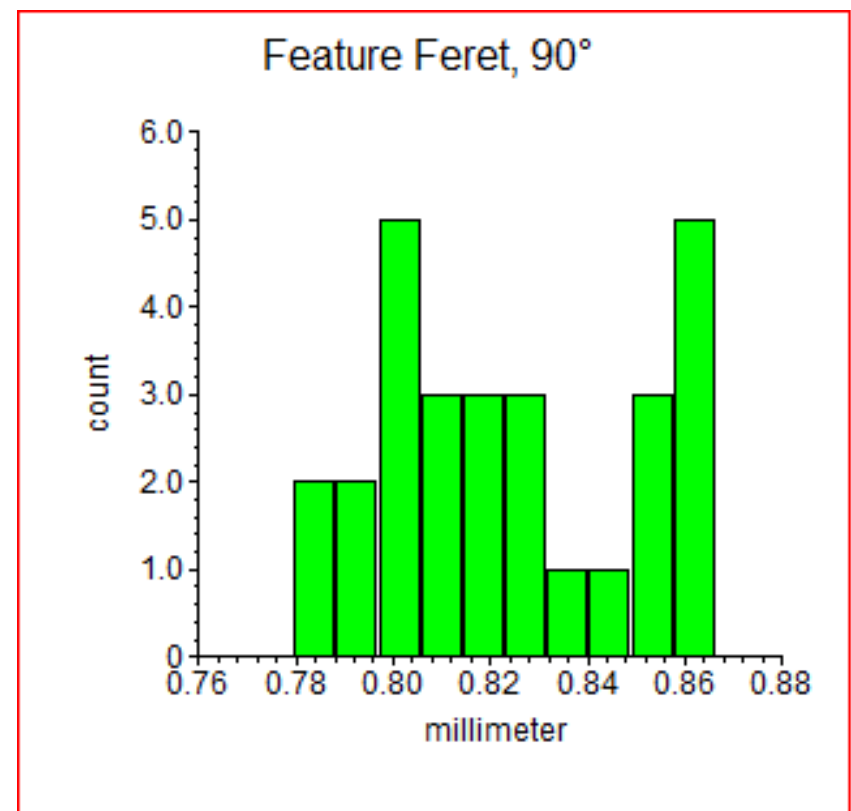

Field Summary

Bitplane

Bitplane 4

Max:

$0.866426 \mathrm{~mm}$

Min:

$0.779783 \mathrm{~mm}$

Mean:

$0.824523 \mathrm{~mm}$

Std Dev:

$0.0266801 \mathrm{~mm}$

Fld Area:

$4.91662 \mathrm{~mm}^{2}$

Tot Area:

$4.91662 \mathrm{~mm}^{2}$

Fld Count:

Obj Count:

28

Over:

Under:

0

Accepted:

$100 \%$

Figura 53 - Histograma com a distribuição das espessuras no núcleo da placa Si833.

Vê-se que os valores obtidos pelo software, a partir da aplicação da Rotina 1, para o mínimo $(0,779783 \mathrm{~mm})$ e o máximo $(0,866426 \mathrm{~mm})$ estão dentro do intervalo de valores especificados por norma $(0,71-0,97 \mathrm{~mm})$, como mostrou a Tabela 2.

Ao mesmo tempo, os valores obtidos pela aplicação do software concordam com os valores medidos manualmente - os quais se localizam no intervalo de $0,82 \mathrm{~mm}$ até $0,90 \mathrm{~mm}$. Vale destacar que, através do método atual de medição, ou método manual, têm-se apenas 6 medidas, enquanto que pelo novo método proposto (método automático criado pelas Rotinas) são obtidas 28 medidas diferentes - apresentadas por suas distribuições no histograma acima.

Os revestimentos das partes terminais da placa Si833 (tanto o superior quanto o inferior) são analisados pelas barras verticais de cor laranja; o histograma gerado pelo software (Figura 54) é dado da maneira que se segue. 


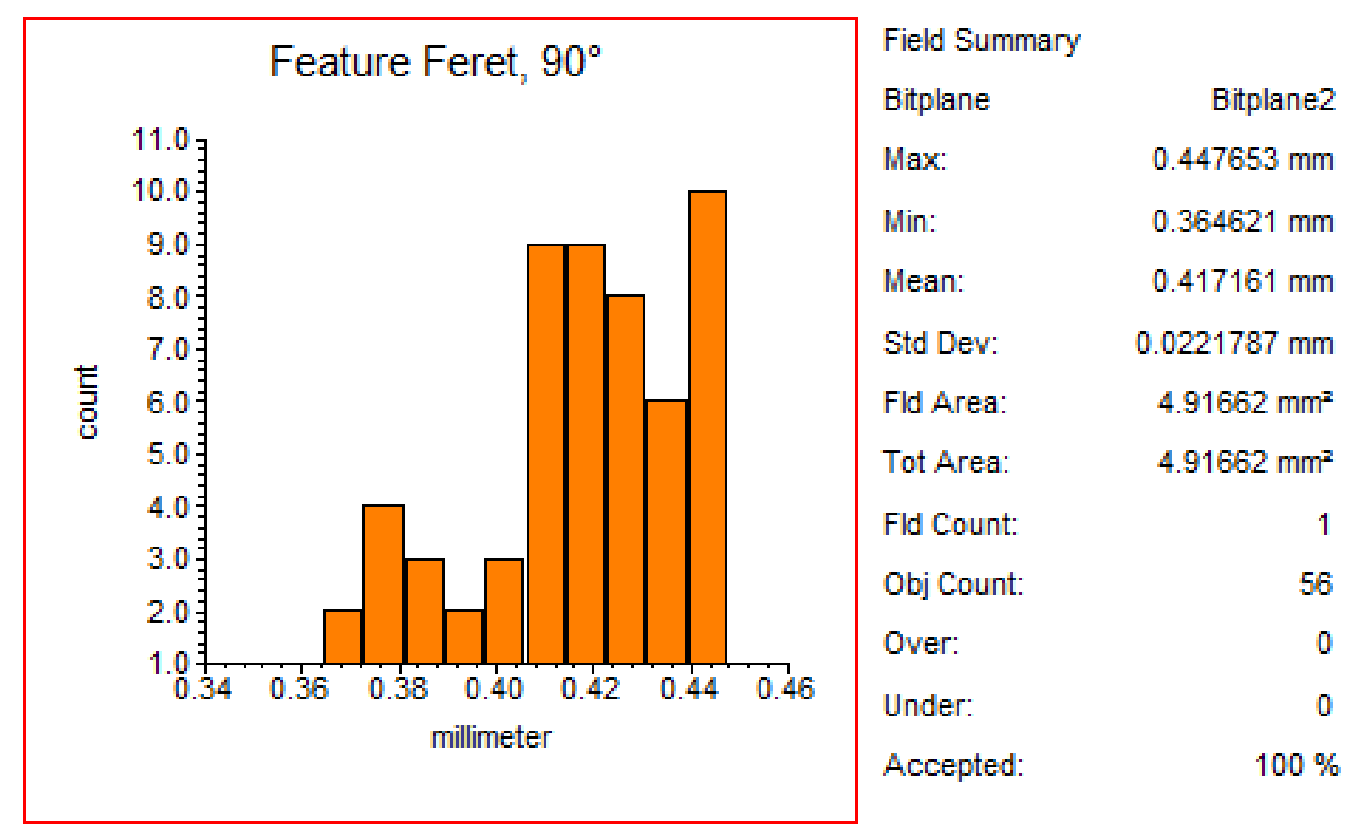

Figura 54 - Histograma com a distribuição das espessuras dos revestimentos da placa Si833.

Também neste caso, verifica-se que os valores encontrados pelo software estão, para o mínimo $(0,364621 \mathrm{~mm})$ e para o máximo $(0,447653 \mathrm{~mm})$, compreendidos no intervalo definido como norma $(0,25-0,46 \mathrm{~mm})$. Os valores obtidos automaticamente concordam com os medidos manualmente - que apresentam como mínimo 0,30 $\mathrm{mm}$ e máximo $0,40 \mathrm{~mm}$. Da mesma forma que antes, há vantagem na aplicação automática da Rotina, já que a partir dela são obtidas 56 medidas diferentes, enquanto manualmente fazem-se apenas 10 (do mesmo frame).

No caso da Rotina 2, para regiões não terminais, ou contínuas, têmse os resultados abaixo. A Figura 55 mostra a imagem original, capturada por Microscopia Eletrônica de Varredura; a Figura 56, a imagem depois da aplicação da Rotina. 


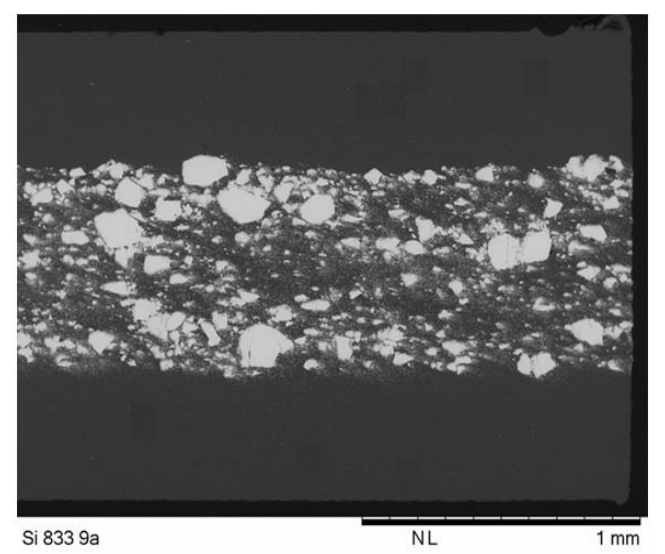

Figura 55 - Imagem original, capturada por MEV (elétrons retroespalhados).

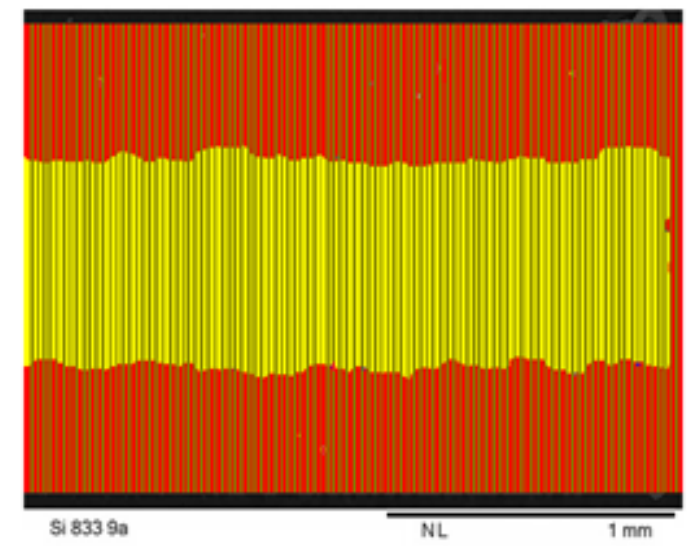

Figura 56 - Imagem após a aplicação da Rotina 2.

Outra vez, o núcleo da placa combustível será analisado com a cor verde, enquanto os revestimentos (inferior e superior, na figura) pelas barras verticais de cor laranja. Adiante, segue o histograma para o núcleo (Figura 57) gerado com as medições feitas através do software, a partir da aplicação da Rotina 2, com as mesmas variáveis que os histogramas anteriores. 


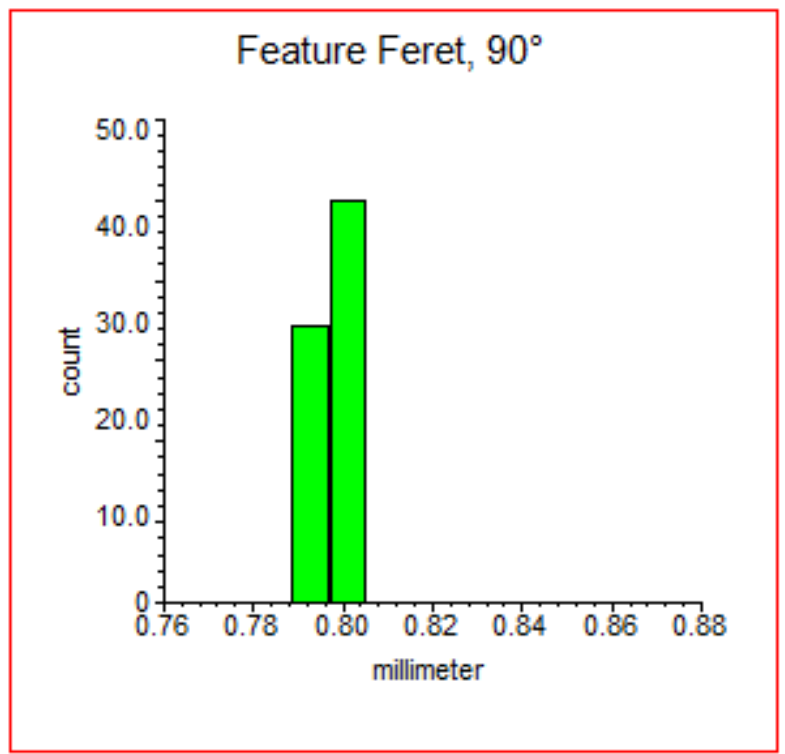

$\begin{array}{lr}\text { Field Summary } & \\ \text { Bitplane } & \text { Bitplane4 } \\ \text { Max: } & 0.803755 \mathrm{~mm} \\ \text { Min: } & 0.788535 \mathrm{~mm} \\ \text { Mean: } & 0.796038 \mathrm{~mm} \\ \text { Std Dev: } & 0.113357 \mathrm{~mm} \\ \text { Fld Area: } & 4.36447 \mathrm{~mm}^{2} \\ \text { Tot Area: } & 4.36447 \mathrm{~mm}^{2} \\ \text { Fld Count: } & 1 \\ \text { Obj Count: } & 73 \\ \text { Over: } & 0 \\ \text { Under: } & 0 \\ \text { Accepted: } & 100 \%\end{array}$

Figura 57 - Histograma com a distribuição das espessuras no núcleo da placa Si833.

Neste histograma (referente à distribuição de espessuras do núcleo da placa, onde está contido o material físsil $\mathrm{U}_{3} \mathrm{Si}_{2}$ ), os valores obtidos pelo software (Rotina 2) estão, para o mínimo $(0,788535 \mathrm{~mm})$ e para o máximo $(0,803755 \mathrm{~mm})$, dentro do intervalo de valores especificados pelas normas de produção $(0,71-0,81 \mathrm{~mm})$, contido na Tabela 2 . No que tange as medidas feitas manualmente (pelo atual processo de medições), os valores obtidos pela aplicação do software concordam com as mesmas - as quais apresentam-se no intervalo de $0,79 \mathrm{~mm}$ a $0,80 \mathrm{~mm}$. Novamente com relação ao número de medições, têm-se apenas 8 medidas quando o frame é analisado manualmente, enquanto que, pelo novo método proposto (método automático criado pelas Rotinas), têm-se 73 medidas diferentes - reiterando vantagem do novo método criado.

Os revestimentos das partes terminais da placa Si833 (tanto o revestimento superior quanto o inferior) são analisados pelas barras verticais de cor laranja; o histograma correspondente, gerado pelo software (Figura 58), é dado da maneira abaixo: 


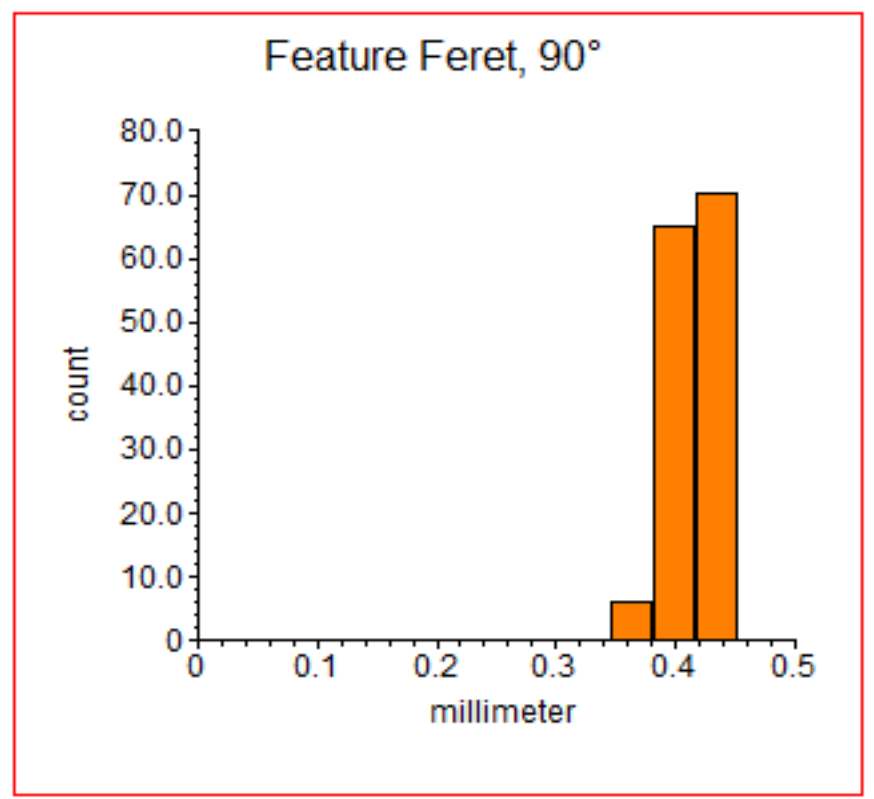

Field Summary

Bitplane

Bitplane2

Max:

Min:

Mean:

Std Dev:

Fld Area:

Tot Area:

FId Count:

Obj Count:

Over:

Under:

Accepted:
$0.457619 \mathrm{~mm}$

$0.347539 \mathrm{~mm}$

$0.437539 \mathrm{~mm}$

$0.0335786 \mathrm{~mm}$

$4.36447 \mathrm{~mm}^{2}$

$4.36447 \mathrm{~mm}^{2}$

1

143

0

0

$100 \%$

Figura 58 - Histograma referente aos revestimentos da placa Si833.

Também aqui, os valores encontrados pelo software estão, para o mínimo $(0,347539 \mathrm{~mm})$ e para o máximo $(0,457619 \mathrm{~mm})$, compreendidos no intervalo definido como norma $(0,33$ - 0,46 mm). Os valores obtidos automaticamente, pela aplicação do software, concordam com os medidos manualmente - que apresentam como mínimo $0,36 \mathrm{~mm}$ e máximo 0,42 $\mathrm{mm}$. Outra vez, tem-se vantagem para a aplicação automática da Rotina: a partir dela são geradas 143 medidas diferentes; manualmente, fazem-se, a partir do mesmo frame, apenas 16.

\subsubsection{Aplicação das Rotinas para a placa Si852}

Para a validação das Rotinas criadas, no caso da terceira placa Si852, escolheu-se o frame correspondente à parte terminal da placa combustível, denominado 1a (referente à parte TLIE), e um frame correspondente ao centro da placa, chamado de $9 d$ (referente à parte $C L)$.

No caso da Rotina 1 (para regiões terminais), foram colhidos os resultados exibidos a seguir. A Figura 59 traz a imagem original, capturada pela técnica de MEV; a Figura 60, a imagem depois da aplicação da Rotina. 


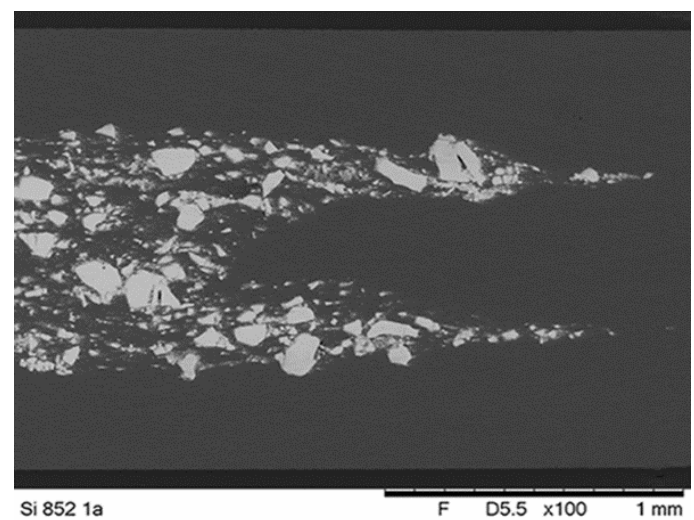

Figura 59 - Imagem original, capturada por MEV (elétrons retroespalhados).

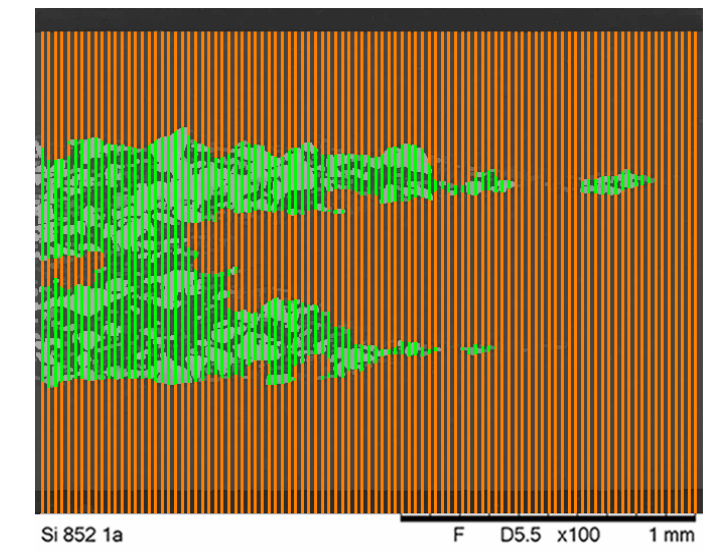

Figura 60 - Imagem após a aplicação da Rotina 1.

O núcleo da placa combustível é representado pela cor verde; seu histograma correspondente, contendo a distribuição de suas espessuras (Figura 61), é gerado automaticamente pelo software, como mostrado abaixo. O histograma é gerado a partir da frequência do número de medidas do intervalo ("count") pela espessura em milímetros $(\mathrm{mm})$ do núcleo da placa combustível. 


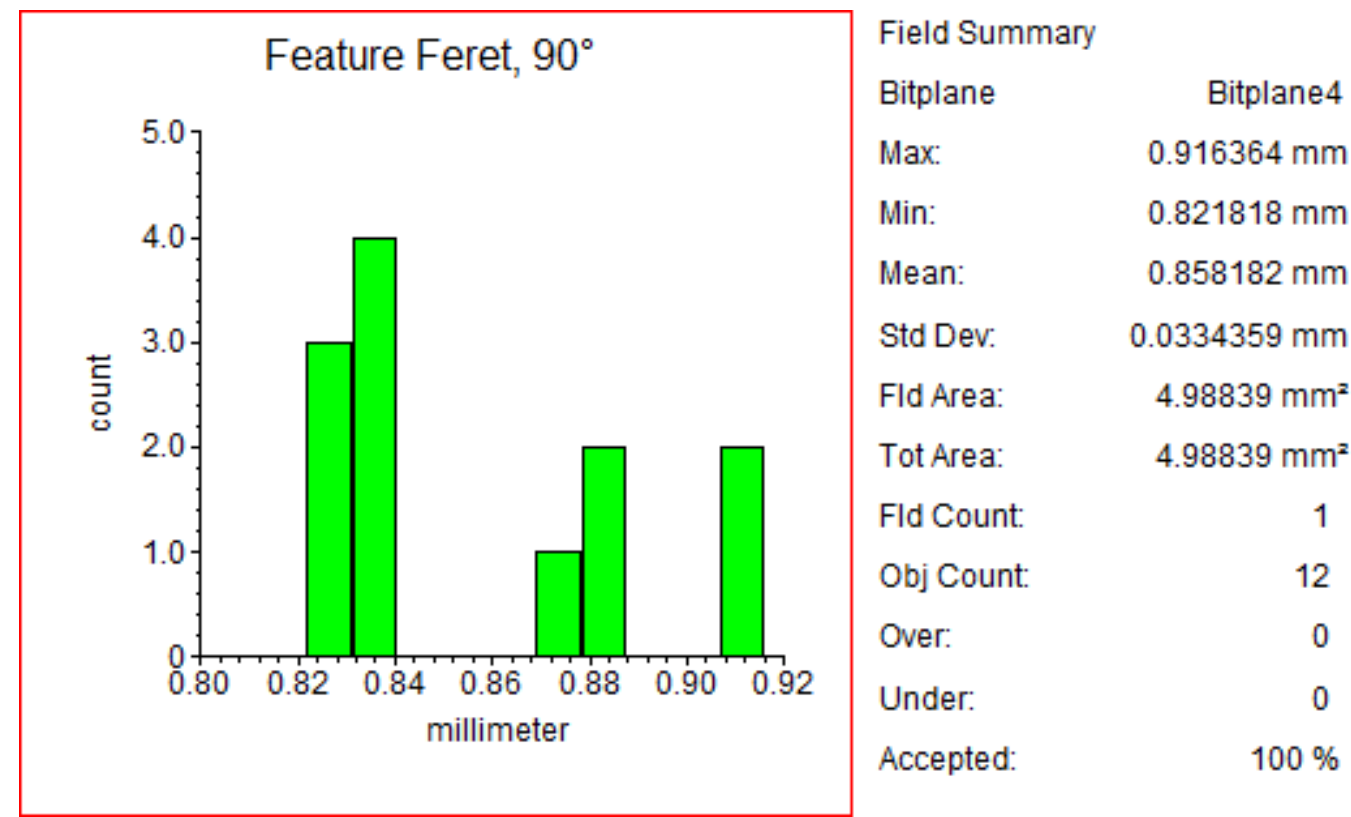

Figura 61 - Histograma com a distribuição das espessuras no núcleo da placa Si852.

No histograma apresentado, observa-se que os valores obtidos pelo software, a partir da aplicação da Rotina 1, para o mínimo $(0,821818 \mathrm{~mm})$ e o máximo $(0,916364 \mathrm{~mm})$ estão contidos no intervalo de valores especificados por norma $(0,71-0,97 \mathrm{~mm})$, como mostrou a Tabela 3 . Além disso, os valores gerados pela aplicação do software concordam com os valores medidos manualmente - os quais apresentam-se no intervalo de 0,82 mm até 0,91 mm.

Através do método atual de medição, ou método manual, são feitas apenas 6 medidas, enquanto pelo novo método proposto (método automático criado pelas Rotinas) têm-se 12 medidas diferentes - apresentadas por suas distribuições no histograma acima.

Os revestimentos das partes terminais da placa Si852 - tanto o revestimento superior quanto o inferior - são analisados pelas barras verticais de cor laranja, e o histograma gerado pelo software (Figura 62) é dado da maneira abaixo. 


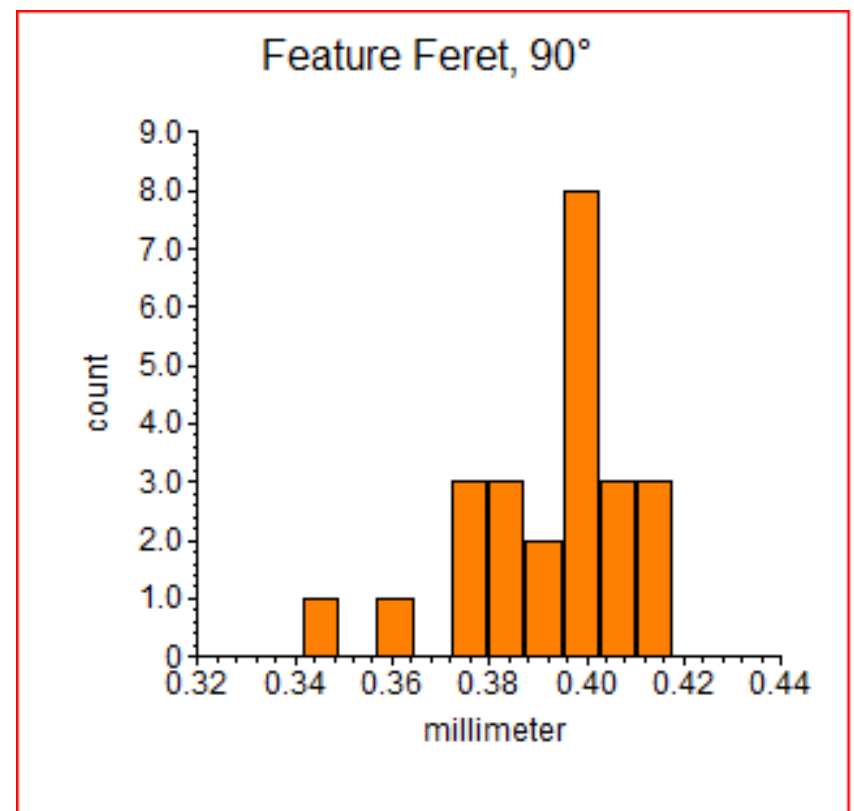

$\begin{array}{lr}\text { Field Summary } & \\ \text { Bitplane } & \text { Bitplane2 } \\ \text { Max: } & 0.418182 \mathrm{~mm} \\ \text { Min: } & 0.341818 \mathrm{~mm} \\ \text { Mean: } & 0.39303 \mathrm{~mm} \\ \text { Std Dev: } & 0.0176171 \mathrm{~mm} \\ \text { Fld Area: } & 4.98839 \mathrm{~mm}^{2} \\ \text { Tot Area: } & 4.98839 \mathrm{~mm}^{2} \\ \text { Fld Count: } & 1 \\ \text { Obj Count: } & 24 \\ \text { Over: } & 0 \\ \text { Under: } & 0 \\ \text { Accepted: } & 100 \%\end{array}$

Figura 62 - Histograma com a distribuição das espessuras dos revestimentos da placa Si809.

Observando o histograma, verifica-se que os valores encontrados pelo software estão, para o mínimo $(0,341818 \mathrm{~mm})$ e para o máximo $(0,418182$ $\mathrm{mm})$, dentro do intervalo definido como norma $(0,25-0,46 \mathrm{~mm})$, e que os valores obtidos automaticamente pela aplicação do software concordam com os valores medidos manualmente - que apresentam como mínimo 0,34 mm e máximo 0,37 $\mathrm{mm}$. Assim como nas situações anteriormente apresentadas, vê-se vantagem na aplicação automática da Rotina, já que a partir dela têm-se 24 medidas diferentes, enquanto que, manualmente, apenas 12 (do mesmo frame).

No caso da Rotina 2, para regiões não terminais, ou contínuas, chegou-se aos resultados apresentados abaixo. As Figura 63 mostra a imagem original, capturada por Microscopia Eletrônica de Varredura; na Figura 64, a imagem depois da aplicação da referida Rotina. 


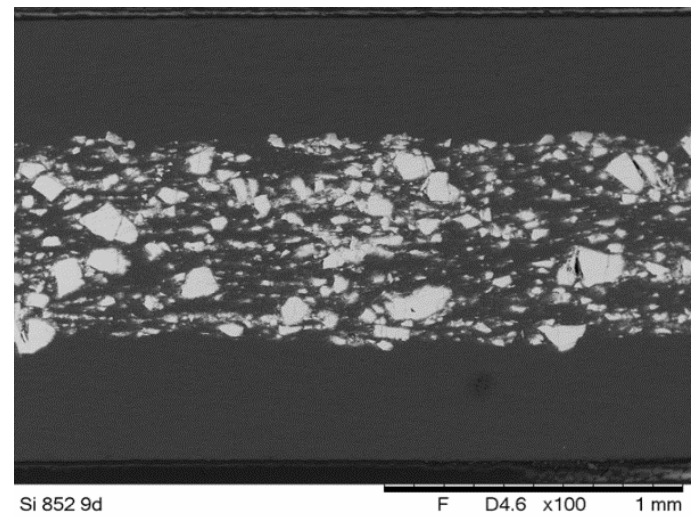

Figura 63 - Imagem original, capturada por MEV (elétrons retroespalhados).

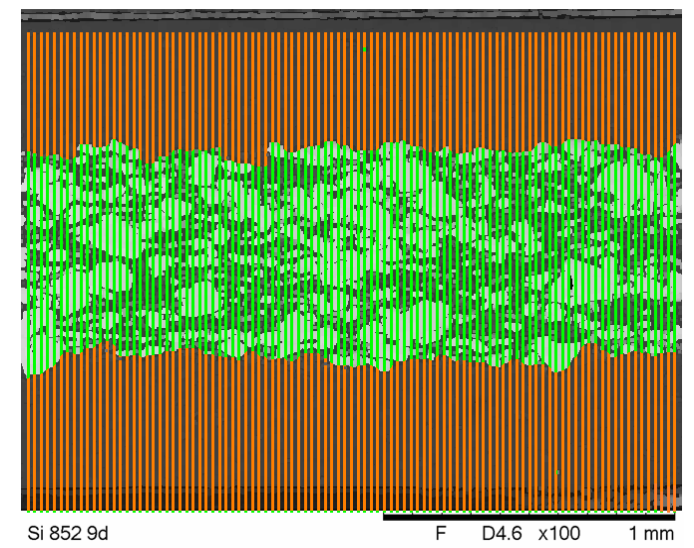

Figura 64 - Imagem após a aplicação da Rotina 2.

Outra vez, o núcleo da placa combustível é analisado com a cor verde; os revestimentos (inferior e superior, na figura), pelas barras verticais de cor laranja. Abaixo, o histograma para o núcleo (Figura 65) gerado com as medições feitas através do software, a partir da aplicação da Rotina 2, com as mesmas variáveis que os anteriormente exibidos. 


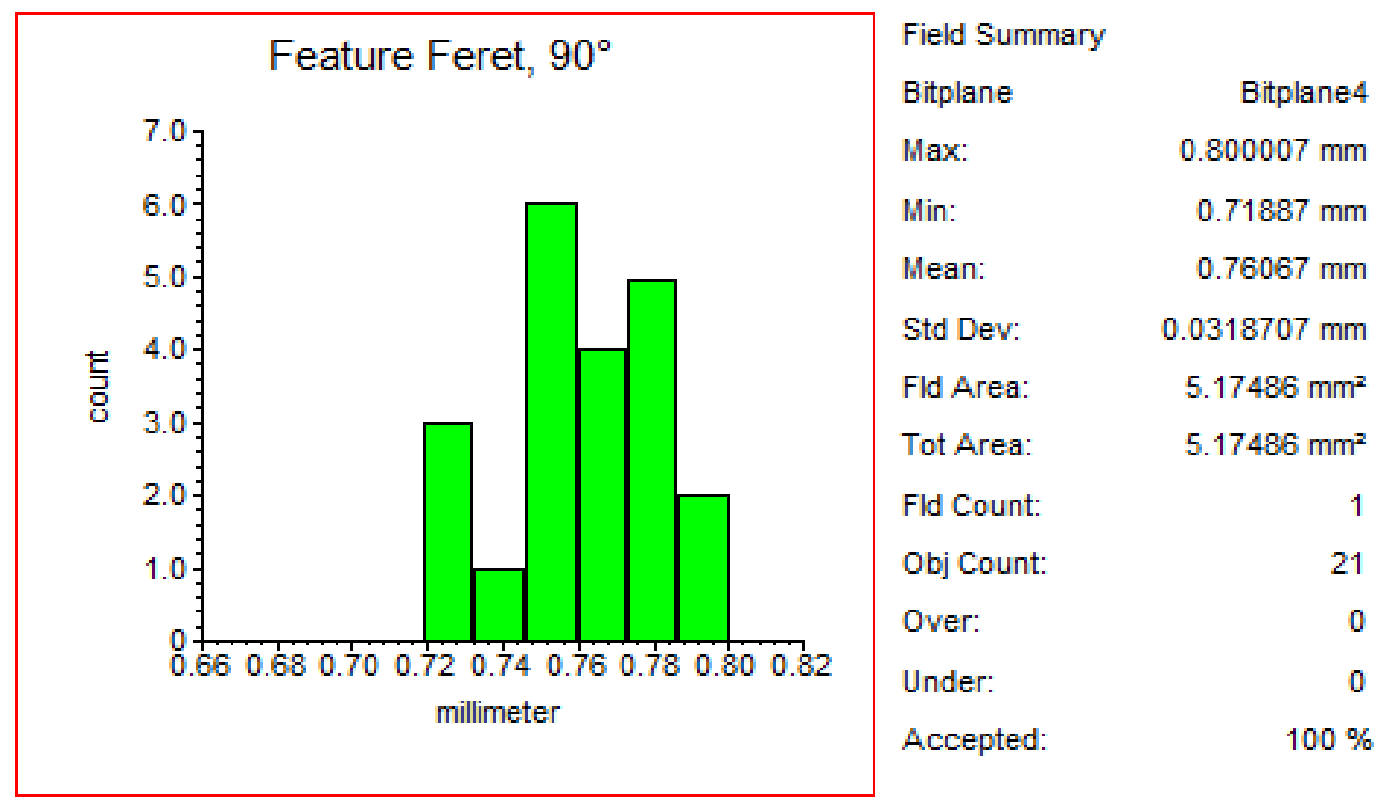

Figura 65 - Histograma com a distribuição das espessuras no núcleo da placa Si852.

No histograma acima (que se refere à distribuição de espessuras do núcleo da placa, onde está contido o material físsil $\mathrm{U}_{3} \mathrm{Si}_{2}$ ), os valores obtidos pelo software (Rotina 2) estão, para o mínimo $(0,71887 \mathrm{~mm})$ e para o máximo $(0,800007 \mathrm{~mm})$, contidos no intervalo de valores especificado pelas normas de produção $(0,71-0,81 \mathrm{~mm})$, exibidos na Tabela 3 . Os valores resultantes da aplicação do software concordam com os obtidos manualmente (pelo atual processo de medições), cujo intervalo situa-se de $0,77 \mathrm{~mm}$ a $0,80 \mathrm{~mm}$.

Com relação ao número de medições, têm-se apenas 8 quando o frame é analisado manualmente. Tal qual nos casos anteriormente expostos, vêse vantagem no novo método (método automático criado pelas Rotinas): através dele são obtidas 21 medidas.

Os revestimentos das partes terminais da placa Si852 (tanto o revestimento superior quanto o inferior) são analisados pelas barras verticais de cor laranja, de forma que o histograma gerado pelo software é dado como se vê na Figura 66: 


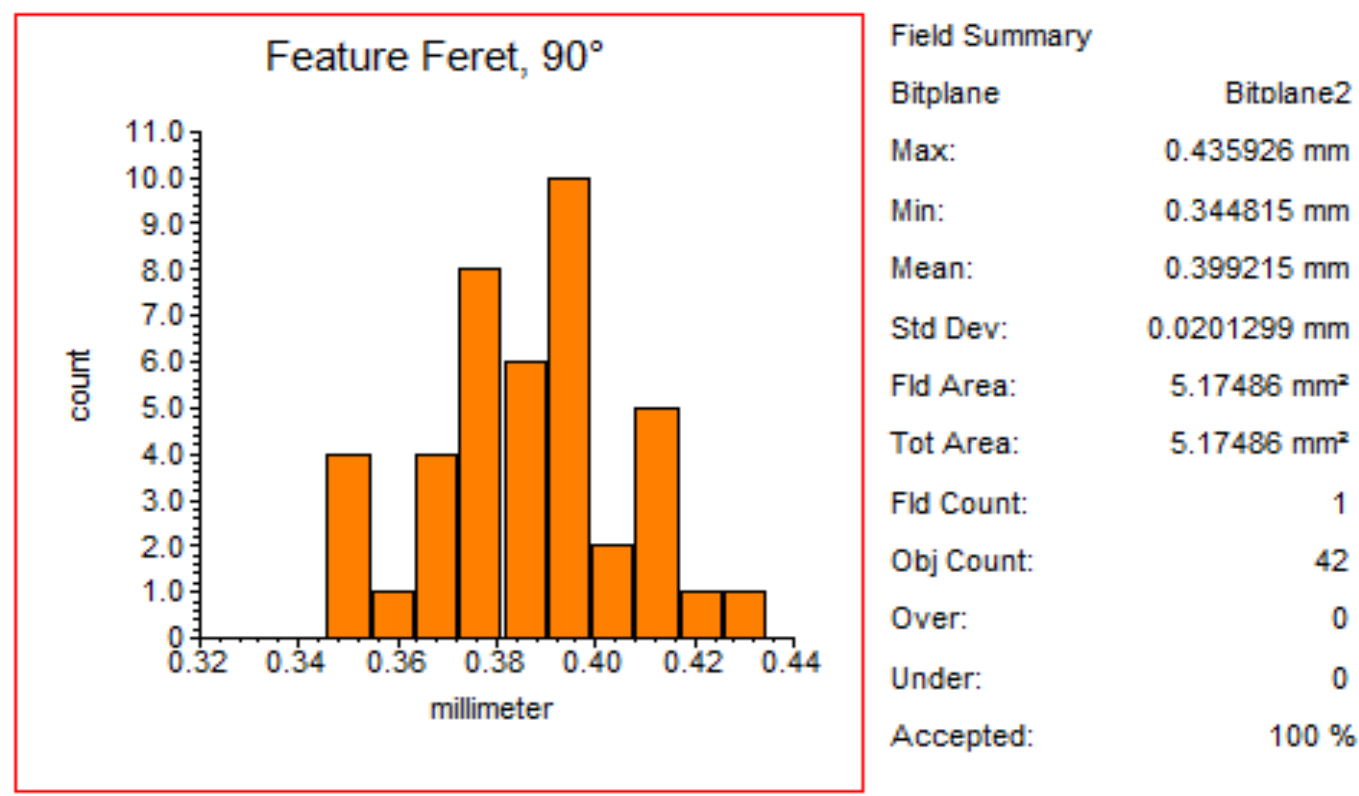

Figura 66 - Histograma referente aos revestimentos da placa Si833.

Também neste caso, os valores encontrados pelo software para o mínimo $(0,344815 \mathrm{~mm})$ e para o máximo $(0,435926 \mathrm{~mm})$ estão compreendidos no intervalo definido como norma $(0,33-0,46 \mathrm{~mm})$. Os valores obtidos automaticamente, pela aplicação do software, concordam com os medidos manualmente - que apresentam como mínimo $0,34 \mathrm{~mm}$ e máximo $0,40 \mathrm{~mm}$. Da mesma forma que antes, tem-se vantagem na a aplicação automática da Rotina, já que a partir dela são obtidas 42 medidas diferentes; fazem-se manualmente, a partir do mesmo frame, apenas 16.

\subsection{Quanto à validação do novo método desenvolvido para medição de espessuras de núcleos e revestimentos de placas combustíveis}

Nota-se que, em todas as medidas feitas pelas duas Rotinas criadas, há perfeita coerência tanto com os dados obtidos manualmente (pelo atual processo em uso para este fim) como com as normas especificadas de produção. Sendo assim, o processo de medição desenvolvido através do software Omnimet Enterprise, que é precisamente o objetivo deste trabalho, foi aplicado e considerado favorável à realização de medições de espessuras de núcleos e revestimentos de placas combustíveis tipo dispersão, validando o método posto em prática. 
Entre as principais vantagens do novo método, foi registrada considerável redução no tempo de realização do processo de medição como um todo - ou seja, desde a preparação das amostras a partir da placa combustível, até a análise dos resultados. Com o processo de medição manual, o tempo necessário é de 288 horas; já a partir da aplicação dos programas desenvolvidos neste trabalho (Rotina 1 e Rotina 2), o tempo para tanto passou a ser de 72 horas. Este fato é de extrema relevância no que diz respeito ao aumento da demanda por elementos combustíveis, fabricados no CCN/IPEN, para o abastecimento do novo Reator Multipropósito Brasileiro (RMB), a ser construído em Iperó (SP). Diante do necessário e expressivo aumento na produção de elementos combustíveis, a ampla e significativa redução no tempo de análise e qualificação das placas do elemento combustível representa grande vantagem metodológica. 


\section{CONCLUSÕES}

Uma vez que o objetivo deste trabalho era o desenvolvimento de um processo de medição de espessuras de núcleos e revestimentos, conclui-se que foi contemplado mediante a criação dos programas apresentados, Rotina $1 \mathrm{e}$ Rotina 2, ambos bastante favoráveis à utilização e qualificação de placas combustíveis.

A partir de todas as medidas feitas, percebeu-se que há total coerência entre os resultados obtidos pelo desenvolvimento do novo processo de medição e os valores das medidas geradas pelo o atual processo - o qual foi, durante este trabalho, chamado de "processo manual". Além disso, todas as medidas realizadas pelo novo processo de medição (proposto neste trabalho) mostram perfeito enquadramento nas normas especificadas pela produção (as quais foram apresentadas nesta dissertação) - o que, junto à coerência das medidas entre os dois processos, faz com que o método computacional desenvolvido pelas Rotinas se torne totalmente válido e eficaz para aplicação de medidas de espessuras de núcleos e revestimentos das placas combustíveis.

Fator importante, que demonstra grande vantagem na adoção do novo procedimento proposto neste trabalho, é a expressiva redução no tempo de execução de preparação, obtenção e análise das imagens das placas combustíveis. Com o procedimento manual, o tempo total do processo é de 288 horas, enquanto o método novo proposto (Rotinas 1 e 2 ) necessita de apenas 72 horas. A importância na redução do tempo está diretamente relacionada ao aumento da demanda por elementos combustíveis fabricados pelo CCN/IPEN, que será o responsável pelo abastecimento do novo Reator Multipropósito Brasileiro (RMB), a ser sediado em Iperó (SP) e cuja previsão para início de atividades é 2015. Diante disso, é indispensável um novo avanço tecnológico, com implantação de técnicas de qualificação mais modernas, na área de fabricação de combustíveis de dispersão do tipo placa, para o uso em reatores de pesquisa e para produção de radioisótopos.

A imagem obtida por microscópio óptico pode ser melhorada, pois, como mostrado neste trabalho, há presença de ruídos (ou aberrações) na obtenção do sinal da imagem. Sugere-se, assim, que a imagem inicial seja feita 
por Microscopia Eletrônica de Varredura (de elétrons retroespalhados) para que se tenha uma melhor qualidade da imagem inicial, sendo esta, após, trabalhada pelas mesmas Rotinas, aumentando a eficiência da obtenção dos dados estatísticos. 


\section{REFERÊNCIAS BIBLIOGRÁFICAS}

[1] PONSARD, B. "Mo-99 supply issues: status report and lessons learned". In: INTERNATIONAL TOPICAL MEETING ON RESEARCH REACTOR FUEL MANAGEMENT, 14TH, March 21-25, 2010, Marrakech, Morocco.

[2] CAMERON, R.; LOKHOV, A. Y.; WESTMACOTT, C. "The supply of medical radioisotopes - an assessment of the market economics, alternative technologies and proposed policy approach to achieving sustainability". In: INTERNATIONAL TOPICAL MEETING ON RESEARCH REACTOR FUEL MANAGEMENT, 15TH, March 20-24, 2011, Rome, Italy.

[3] EUROPEAN NUCLEAR SOCIETY - ENS. "The medical isotope crisis". http://www.euronuclear.org/pdf/The-medical-isotope-crisis-2009-09-15.pdf.

Acessado em 20 de outubro de 2012.

[4] OSSO Jr, J. A.; TEODORO, R.; DIAS, C. R. B. R.; BEZERRA, R.R.L.; VILLELA. J. L.; CORREIA, PERROTTA, J. A.; PEREIRA, G. A.; ZAPPAROLI Jr, C. L.; MENGATTI, J. "Brazilian strategies to overcome molybdenum crisis: present and future perspectives of the Multipurpose Research Reactor". In: INTERNATIONAL TOPICAL MEETING ON RESEARCH REACTOR FUEL MANAGEMENT, 15TH, March 20-24, 2011, Rome, Italy.

[5] OBADIA, I. J,; PERROTA, J. A. "A sustainability analysis of Brazilian Multipurpose Reactor project". In: INTERNATIONAL TOPICAL MEETING ON RESEARCH REACTOR FUEL MANAGEMENT, 14TH, March 21-25, 2010 , Marrakech, Marocco.

[6] DURAZZO, M., URANO de CARVALHO, E. F., SALIBA-SILVA, A.M., Souza, J. A. B., RIELLA, H. G. Fabricação de elementos combustíveis a base de $\mathrm{U}_{3} \mathrm{Si}_{2}$ no Brasil. Resvista Brasileira de Pesquisa e Desenvolvimento, v.9, p. 18-28, 2007.

[7] CUNNINGHAM, J.E.; BOYLE, E.J. MTR-Type fuel elements. In: UNITED NATIONS. Peaceful uses atomic energy: proceedings of the International Conference on..., held in Geneva, 8-20 Aug. 1955. V. 9: Reactor technology and chemical processing. New York, N.Y., 1956. p. 203-7.

[8] KAUFMAN, A.R. Nuclear reactor fuel elements, metallurgy and fabrication. New York, N.Y. Interscience, 1962.

[9] DURAZZO, M., URANO de CARVALHO, E. F., SALIBA SILVA, A. M., SOUZA, J. A. B,. RIELLA, H. G. Current status of U3Si2 fuel elements fabrication in Brazil. In: INTERNATIONAL MEETING ON REDUCED ENRICHMENT FOR 
RESEARCH AND TEST REACTORS, Prague. Proceedings... . Illnois: Argonne National Laboratory, 2007.

[10] HOLDEN, A.N. Dispersions Fuel Elements. New York, N.Y., Gordon \& Breach, 1967.

[11] CUNNINGHAM J.E.; BEA VER, R.J.; THURBER W.C.; WAUGH, C. Fuel Dispersions in Aluminium-Base Elements for Research Reactors. In: ATOMIC ENERGY COMISSION. Fuel Elements Conference held in Paris, 18-23 November, 1957. Oak Ridge, Tenn., 1958, V.1. p. 269-97. TID -7546.

[12] SALLER, H.A. Preparation, Properties and Cladding of Aluminum-Uranium Alloys. In: UNITED NA TIONS. Peaceful Uses of Atomic Energy: proceedings of the Intemational Conference on..., held in Geneva, 8-20 Aug. 1955. V.9: Reactor Technology and Chemical Processing. New York, N.Y., 1956. p. 214-20.

[13] THURBER, W.C.; BEA VER, R.J. Segregation in Uranium-Aluminum Alloys and its Effect on the Fuel Loading of Aluminum-Base Fuel Element. In: USAEC: Reactor Fuel Measurements Techniques Symposium, held in EastLansing, Michigan, June 18-20, 1958. Oak Ridge, Tenn., 1958. p. 9-29. TID -7560.

[14] LENNOX, D.H.; KELBER, C.N. Summary Report on the Hazards of the Argonaut Reactor. Lemont, m., Argonne National Lab., Dec. 1956. ANL - 5647.

[15] KUCERA, W.J.; LEITTEN, C.F.; BEA VER, R.J. Specifications and Procedures Used in Manufacturing $\mathrm{U}_{3} \mathrm{O}_{8}$-Aluminium Dispersion Fuel Elements for Core I of the Puerto Rico Research Reactor. Oak Ridge, Tenn., Oak Ridge National Lab., 1963. ORNL - 3458.

[16] KNIGHT, R.W.; BINNS, J.; ADAMSON Jr., G.M. Fabrication Procedures for Manufacturing High Flux Isotope Reactor Fuel Elements. Oak Ridge, Tenn., Oak Ridge National Lab., June 1968. ORNL - 4242.

[17] BEAVER, R.I.; ADAMSON JR., G.M.; PATRIARCA, P. Procedures for Fabricating Aluminium-Base ATR Fuel Elements. Oak Ridge, Tenn., Oak Ridge National Lab., June 1964. ORNL - 3632.

[18] TRAVELLI, A. Current Status of the RERTR Program. In: Development Fabrication and Application of Reduced-Enriched Fuels for Research and Test Reactor: proceedings held in Argonne, III., 12-14 November, 1980. CONF 801144 .

[19] MARTINS, I.C. Estudos microestruturais sobre interações químicas na liga U-Mo com Al. 2010. Dissertação (Mestrado) - Instituto de Pesquisas Energéticas e Nucleares, São Paulo.

[20] BRESSIANI, J.C. Desenvolvimento de combustível tipo placa, com núcleo constituído por dispersão U-Al, para reatores de ensaios de 
materiais. 1979. Dissertação (Mestrado) - Instituto de Pesquisas Energéticas e Nucleares, São Paulo.

[21] HOFMAN, G.L. et al. Progress in development of low-enriched U-Mo dispersion fuels", RRFM Meeting, 2002.

[22] SIMOES, A.V. Desempenho sob irradiação de combustíveis a dispersão de MTR. 1993. Dissertação (Mestrado) - Instituto de Pesquisas Energéticas e Nucleares, São Paulo

[23] U.S. REGULATORY COMMISSION. Safety Evaluation Report related to the Evaluation of Low-Enriched Uranium Silicide-Aluminum Dispersion Fuel for Use in Non-Power Reactors. United States Nuclear Regulatory Commission, July 1988. NUREG-1313.

[24] SNELGROVE, J.L.; DOMAGALA, R.F.; HOFMAN, G.L.; WIENCEK, T.C.; COPELAND, G.L.; HOBBS, R.W.; SENN, R.L. The Use of $\mathrm{U}_{3} \mathrm{Si}_{2}$ Dispersed in Aluminum in Plate-Type Fuel Elements for Research and Test Reactors. Argonne National Laboratory, Argonne, Illinois, October 1987. ANL/RERTR/TM-11.

[25] SNELGROVE, J.L.; DOMAGALA, R.F.; HOFMAN, G.L.; WIENCEK, T.C.; COPELAND, G.L.; HOBBS, R.W.; SENN, R.L. The Use of $\mathrm{U}_{3} \mathrm{Si}_{2}$ Dispersed in Aluminum in Plate-Type Fuel Elements for Research and Test Reactors. Argonne National Laboratory, Argonne, Illinois, October 1987. ANL/RERTR/TM-11.

[26] SNELGROVE, J.L.; DOMAGALA, R.F.; HOFMAN, G.L.; WIENCEK, T.C.; COPELAND, G.L.; HOBBS, R.W.; SENN, R.L. The Use of $\mathrm{U}_{3} \mathrm{Si}_{2}$ Dispersed in Aluminum in Plate-Type Fuel Elements for Research and Test Reactors. Argonne National Laboratory, Argonne, Illinois, October 1987. ANL/RERTR/TM-11.

[27] NAZARÉ, S. Low Enrichment Dispersion Fuels for Research and Test Reactors. Journal Nucl. Mat.,v.124, p.14, 1984.

[28] SALIBA-SILVA, A.M.; URANO DE CARVALHO, E.F.; DURAZZO, M.; RIELLA, H.G. Research Reactor fuel fabrication to produce radioisotopes. Radioisotopes-Applications in Physical Sciences. InTech, 2011.

[29] BUEHLER. Operation and Maintenance Instructions. Manual do equipamento. 1993.

[30] BUEHLER. Institute for microstructural Analysis. Manual do equipamento. 2002. 